\title{
Autonomous Lawmaking: \\ The Case of the "Gypsies"
}

\author{
Walter Otto Weyrauch ${ }^{\dagger}$ and Maureen Anne Bell ${ }^{\dagger \dagger}$
}

\author{
CONTENTS
}

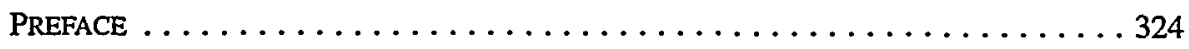

I. INTRODUCTION: SOURCES OF LAW . . . . . . . . . . . . 326

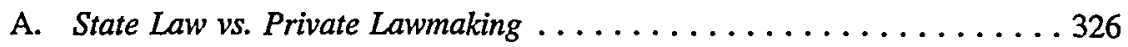

B. Fostering Respect for Private Lawmaking . . . . . . . . . . . 332

1. Parallels Between Private Lawmaking and Tribal Law . . . . . . 332

2. Reasons for Selecting Gypsy Law . . . . . . . . . . . 333

II. IMPEDIMENTS TO RESEARCH ON GYPSY LAW . . . . . . . . . . 334

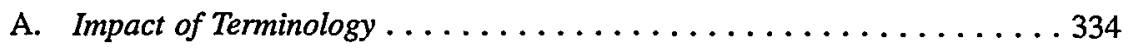

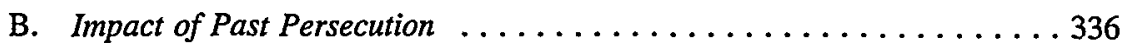

C. A Suggested Method for the Study of Gypsy Law . . . . . . . . . . . 339

III. GYPSY LAW . . . . . . . . . . . . . . . . . . 340

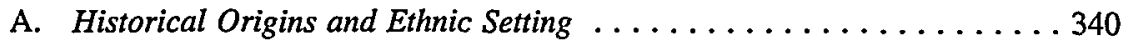

B. Functions of Concepts of Impurity (Marime) . . . . . . . . . 342

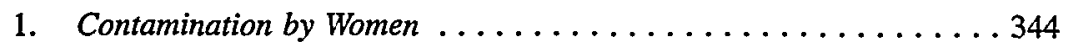

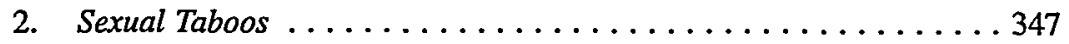

3. Hygienic Matters ...................... . . 349

4. Social Transgressions . . . . . . . . . . . . . . 351

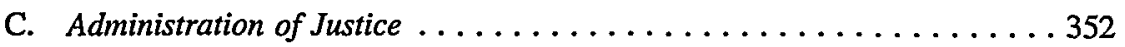

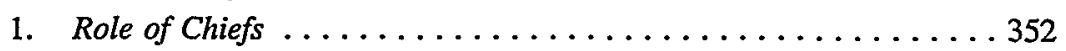

2. Role of Courts (Kris) . . . . . . . . . . . . . 354

3. Legal Sanctions ...................... 358

$\dagger$ Clarence J. TeSelle Professor of Law, University of Florida; Honorarprofessor, Johann Wolfgang Goethe Universität, Fachbereich Rechtswissenschaft, Frankfurt am Main, Germany.

it Adjunct Professor, Legal Studies Program, College of Health and Public Affairs, University of Central Florida; associated with Bogin, Munns \& Munns, Orlando, Florida.

We are indebted to Frank Allen, Gunther Arzt, Stanley Ingber, Lynn LoPucki, and Rosalie Sanderson for their valuable suggestions. Special thanks are due to Ian Hancock, a British-Hungarian Rom and Professor of Linguistics at the University of Texas, for his numerous comments and valuable critique on earlier drafts of the manuscript. 
D. Conflict Between Host Legal System and Gypsy Law . . . . . . . . 360

E. Previous Attempts at Theory ... . . . . . . . . . . . . . . . . 367

1. Some Trends in the Nonlegal Literature . . . . . . . . 367

2. Integration, Assimilation, and Adaptation ........... 370

IV. Central features of Gypsy law and Other Forms of Private

LAWMAKING . . . . . . . . . . . . . . . . . . 373

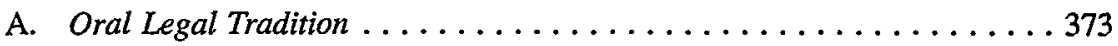

1. Legal Functions of Memory . . . . . . . . . . . . 374

2. Oral and Printed Law Contrasted ... . . . . . . . . . . . . . 377

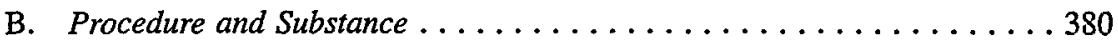

1. Role of Language . . . . . . . . . . . . . . . . . 380

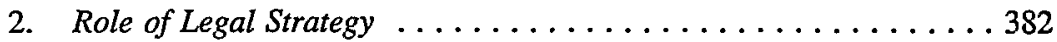

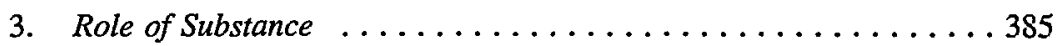

C. Laws of Evidence . . . . . . . . . . . . . . . . . . . 389

1. Absence of Exclusionary Rules . . . . . . . . . . . . 389

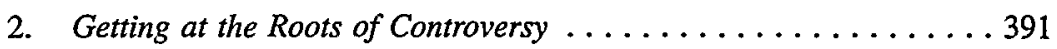

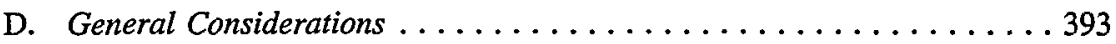

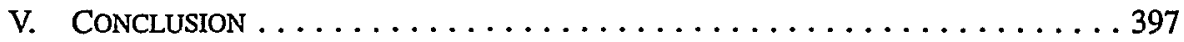

\section{PREFACE}

This Article is a study of the laws and legal processes of the Romani people, traditionally known as Gypsies. ${ }^{1}$ The account of the autonomous legal system of the Romani people provided here may appear so incredible that some readers may believe that it is based not on research but on insupportable construction. In fact, this Article finds its support in the extensive and amorphous nonlegal literature and from the few Romani sources available.

1. The terminological difficulties regarding the word "Gypsy," and the conceptual problems resulting from them, are described in detail in Part II, infra. "Gypsy" is a designation used by non-Gypsies to describe the ethnic people who call themselves "Roma." English-language scholarship still refers widely to "Gypsies" rather than "Roma." See Jan Yoors, Gypsy, 13 ENCYClOPEDIA AMERICANA 646, 646 (Int'l ed. 1989) [hereinafter Yoors, AMERICANA]; Gypsy, 5 NEw ENCYCLOPEDIA BRITANNICA 593 (15th ed. 1990). Difficulties exist in other languages as well. The German word Zigeuner is no longer used in scholarly writings. A German author reports that, consequently, she began using the word "Roma" in her writings. Rumanian Gypsies, however, objected to this usage. They preferred to be called Zigeuner. Herta Müller, Der Staub ist blind-die Sonne ein Krüppel, FRANKFURTER ALlgeMEINE ZeITUNG, May 4, 1991, Bilder und Zeiten, at 1,2 (postscript to article).

This Article uses the term "Gypsy" interchangeably with the term "Roma" to reflect the fact that its research depends on both Gypsy and non-Gypsy sources. Gypsy authors such as Ian Hancock have used the term "Gypsy" when addressing a non-Gypsy audience. See IAN HANCOCK, THE PARIAH SYNDROME: AN ACCOUNT OF GYPSY SLAVERY AND PERSECUTION (1987) [hereinafter HANCOCK, PARIAH SYNDROME]. Throughout this Article we use the alternative spelling "Rumania" for Romania to stress that the term "Roma" for Gypsies is not linguistically related to Rumanian. This spelling is used by Hancock for the same reason. 
The Article discusses the highly developed internal laws of the Gypsies to illustrate how private lawmaking is central to the everyday workings of society. The Vlax Roma, the largest Gypsy group in the United States, have laws that are generations old, administered by their own courts (kris) and judges (krisnitorya). For centuries, their courts have functioned autonomously virtually without regard for those of the host country. Although these judicial gatherings are not officially recognized and, if noticed, tend to be misunderstood, they effectively impose sanctions within their own communities. A detailed examination of the Gypsy legal system can sensitize us to the private lawmaking that takes place in American society.

Analysis of law usually focuses on the law of the state. This Article, however, uses the law of the Gypsies as an example of an autonomous legal system, one which operates outside the parameters of state law. The Article argues that in most cases in which the autonomous legal system of the Gypsies clashes directly with the law of the host country, the private legal system of the Gypsies prevails. More frequently, however, autonomous legal systems and state law interact in a more subtle manner. Even when they do not come into conflict, each can powerfully influence the other. Thus, the norms of any legal system, public or private, may only be preserved intact through a cultural isolation which is nearly impossible to achieve.

Apart from its central concern with autonomous private lawmaking, this Article is timely for its consideration of the relationship between ethnicity and law. Contemporary ethnic tensions have been a major factor in recent bitter confrontations around the world. Bosnia-Herzegovina, the Near East, Armenia and Azerbaijan, South Africa, India, and Sri Lanka, for example, all have been affected by ethnic confrontation. Within the United States, the 1992 Los Angeles riots may have been fueled in part by perceptions of the relationship between ethnicity and law. The Gypsies themselves are increasingly targets of persecution in Eastern Europe, where the collapse of communism has revived not only nationalism and ethnic pride, but also fanaticism and racial hatred. That hatred is often directed against the Gypsies who, as scapegoats, are blamed for many past and present ills of society. ${ }^{2}$ Some of this racial animosity may stem from ignorance and misinterpretation of the Gypsies' internal norms, which set them apart from other cultures.

Part I of this Article discusses the concept of autonomous lawmaking and how it has been neglected in legal scholarship. It then explains why the Gypsies provide an optimal example for examining private law. Part II describes how problems of terminology and language render terms originating from non-Gypsy sources inadequate and misleading. It then traces the severe

2. Don Pavel, Wanderers: Romania's Hidden Victims: New Assaults upon the Gypsy Minority, NEW REPubliC, Mar. 4, 1991, at 12 (Juliana G. Pilon trans.); Carol J. Williams, Gypsies Feel Curse of Hatred, L.A. TIMIES, Dec. 20, 1991, at Al. 
persecution of the Romani people from the Middle Ages to the present times, and discusses how this persecution has permanently affected the willingness of the Gypsies to collaborate with any structured inquiry into their culture, especially their law.

Part III presents the essential features of Romani law, including its sanctions. It discusses the significance of Romani law for the survival of Romani culture. Part IV analyzes some crucial features shared by Gypsy law and other forms of private lawmaking in our own legal culture. It examines the roles of oral legal traditions, language, and legal strategies as they relate to the substance of law. In addition, it discusses how the laws of evidence in private lawmaking operate. Part V concludes the Article by suggesting a concise theoretical framework to understand better private lawmaking and its relationship to state law.

\section{INTRODUCTION: SOURCES OF LAW}

\section{A. State Law vs. Private Lawmaking}

Commonly held assumptions about lawmaking have profound theoretical and practical consequences. The traditional view is that law originates with the state. ${ }^{3}$ Even if we recognize contracts as a form of private lawmaking, it is assumed that we make formal agreements essentially with delegated state power. ${ }^{4}$ According to these notions, the legitimacy of lawmaking depends on the authority of the state, or at least on the degree to which the state tolerates private lawmaking. This view of the primacy of state law is of relatively recent origin. It can be traced to times of absolutism, when monarchs were perceived to be the ultimate lawgivers. ${ }^{5}$ Created by the monarch for self-serving purposes, this conception of law reflects ideas that may no longer be applicable under contemporary standards and values. The time is ripe to reexamine this limited view of law and to broaden its scope.

3. See, e.g., W. FRIEDMANN, Legal TheORY 120-22, 258-60 (5th ed. 1967) (discussing theories of Thomas Hobbes and John Austin); see also H.L.A. HART, THE CONCEPT OF LAW 49-76 (1961) (discussing relationship between sovereign and society); 1 HANS KELSEN, GENERAL THEORY OF LAW AND STATE 181-207 (Anders Wedberg trans., 1945); JULIUS STONE, LEGAL SYSTEMS AND LAWYERS' REASONINGS 63-136 (1964) (discussing theories of John Austin and Hans Kelsen). The jurisprudential conception of legal positivism often mentioned in this context is less clear than commonly assumed. See Helen Silving, Positive Natural Law, 3 NAT. L.F. 24, 27-30 (1958).

4. See, e.g., HART, supra note 3 , at 94 ("We have already described in some detail the rules which confer on individuals power to vary their initial positions under the primary rules. . . The kinship of these rules with the rules of change involved in the notion of legislation is clear, and as recent theory such as Kelsen's has shown, many of the features which puzzle us in the institutions of contract or property are clarified by thinking of the operations of making a contract or transferring property as the exercise of limited legislative powers by individuals."); see also KELSEN, supra note 3, at 204 (noting delegation of power to contract from legal order).

5. EUGEN EHRLICH, FUNDAMENTAL PRINCIPLes OF THE SOCIOLOGY OF LAW 14-38 (Walter L. Moll trans., 1936). 
Eugen Ehrlich suggested that in the Middle Ages, prior to the rise of monarchies when state authority as we understand it arose, most lawmaking took place in a variety of autonomous institutions and groups, such as cities and guilds, leaving large geographic areas unregulated. ${ }^{6}$ Without an effective central government, private organizations could maintain considerable autonomy in making rules to govern their own affairs. ${ }^{7}$

Even though the modern state reaches across broad swaths of territory, its regulations do not always penetrate all social ordering. The modern equivalent of the laws of autonomous medieval groups is the informal lawmaking which takes place whenever people join in groups, associations, or institutions to pursue common objectives. This Article adopts the broad definition of law proposed by Cowan and Strickland in 1965:

6. Id. at 14-38. For an analysis of Ehrlich's theories about the evolution of law, see William H. Page, Professor Ehrlich's Czernowitz Seminar of Living Law, in 1914 Proc. Ass'N. AM. L. SCH. 46, reprinted in READINGS IN JURISPRUDENCE 825 (Jerome Hall ed., 1938). The theories of von Savigny similarly argue that law, like language, forms within peoples "by internal silently-operating powers, not by the arbitrary will of a law-giver." FRIEDRICH KARL vON SAVIGNY, OF THE VOCATION OF OUR AGE FOR LEGISLATION AND JURISPRUDENCE 30 (Abraham Hayward trans., spec. ed. 1986) (1814). Ehrlich also acknowledged his indebtedness to Otto von Gierke for his writings about the internal ordering of associations. EHRLICH, supra note 5, at 24 (referring to OTTO vON GIERKE, DAS DEUTCHE GENOSSENSCHAFTSRECHT (1868)). For further background on Gierke's political philosophy, see generally OTTO VON GIERKE, POLITICAL THEORIES OF THE MIDDLE AGES (Frederic W. Maitland trans., 1900).

Contemporary scholarship has focused primarily on microlegal systems, which includes small groups, aggregated units that are characterized by little or no commonality of purpose, and even casual encounters between individuals. See generally Thomas A. Cowan \& DONALD A. STRICKLAND, THE LEgal STRUCTURE OF A CONFINED MICROSOCIETY (University of California, Berkeley Working Paper No. 34, 1965); Group DyNaMic LAw: EXPosition and PraCtiCE (David A. Funk ed., 1988); Leopold J. POSPISIL, ANTHROPOLOGY OF LAV: A COMPARATIVE THEORY (1971) [hereinafter POSPISIL, ANTHRopology of LaW]; Walter O. Weyrauch, THE LaW OF a SMall Group (University of California, Berkeley Working Paper No. 54, 1967) [hereinafter WEYRAUCH, THE LAW OF A SMALL GrouP]; Walter O. Weyrauch, The "Basic Law" or Constitution of a Small Group, 27 J. SoC. IssuEs 49 (1971), reprinted in LAW, JUSTICE, AND THE INDIVIDUAL IN SOCIETY 41 (June L. Tapp \& Felice J. Levine eds., 1977) [hereinafter Weyrauch, Basic Law]; Walter O. Weyrauch, Law in Isolation-the Penthouse Astronauts, TRANS-ACTION, June 1968, at 39 [hereinafter Weyrauch, Law in Isolation]; Michael Reisman, Lining Up: The Microlegal System of Queues, 54 U. CIN. L. REV. 417 (1985) [hereinafter Reisman, Lining Up]; Michael Reisman, Looking, Staring and Glaring: Microlegal Systems and Public Order, 12 DENV. J. INT'L L. \& POL'Y 165 (1983) [hereinafter Reisman, Looking, Staring and Glaring]; Michael Reisman, Rapping and Talking to the Boss: The Microlegal System of Two People Talking, in CONFLICT AND INTEGRATION: COMPARATIVE LAW IN THE WORLD TODAY 61 (Institute of Comparative Law in Japan ed., 1988) [hereinafter Reisman, Rapping].

Stewart Macaulay has written numerous articles about the development of informal legal culture using examples in the United States. E.g., Stewart Macaulay, Images of Law in Everyday Life: The Lessons of School, Entertainment, and Spectator Sports, 21 LAW \& SOC'Y REV. 185 (1987); Stewart Macaulay, Non-contractual Relations in Business: A Preliminary Study, 28 AM. Soc. REv. 55 (1963); Stewart Macaulay, Popular Legal Culture: An Introduction, 98 YALE L.J. 1545 (1989). Recently scholars have pointed to the Jewish legal tradition as expressed in the Torah to provide further support for their argument that law should be defined by communal acceptance rather than by reference to the law of the state. E.g., Robert M. Cover, The Supreme Court, 1982 Term-Foreword: Nomos and Narrative, 97 HARV. L. REV. 4, 11-19 (1983); Suzanne L. Stone, In Pursuit of the Counter-Text: The Turn to the Jewish Legal Model in Contemporary American Legal Theory, 106 HARV. L. Rev. 813, 865-72 (1993) [hereinafter Stone, Counter-Text].

7. For a discussion of autonomy in German law, see JOHN C. GRAY, THE NATURE AND SOURCES OF THE LAW 158-59, 325-28 (2d ed. 1921); see also Cover, supra note 6, at 26-33 (discussing origin of legal meanings in insular autonomous communities). 
Law is an existential condition in which men are carriers of rights and duties, privileges and immunities. No formal structure supporting the system of law need be visible. Those accustomed to seeing law only in its formal institutions, in terms of statutes, decisions, judges, legislators and administrators miss the point. Law can be found any place and any time that a group gathers together to pursue an objective. The rules, open or covert, by which they govern themselves, and the methods and techniques by which these rules are enforced is the law of the group. Judged by this broad standard, most law-making is too ephemeral to be even noticed. But when conflict within the group ensues, and it is forced to decide between conflicting claims, law arises in an overt and relatively conspicuous fashion. The challenge forces decision, and decisions make law. ${ }^{8}$

This description covers a wide range of human activities in a continuum that encompasses tribal law and other examples of informal lawmaking, as well as the more formal charters and bylaws of corporations.

The extent to which such laws are visibly formalized may affect the relationship between private lawmaking authority and state law. If private lawmaking is more visible, the state will assume control by legislation and regulation. Less de facto autonomy will remain in the hands of the private organization. Frequently, the visible forms of private lawmaking such as charters and bylaws coincide with unwritten customs which are enforced by sanctions. Thus, quite independently from the mandates of the state, various levels of private law may either supplement or conflict with each other. Any corporate lawyer is aware of corporate customs supported by sanctions that supplement but sometimes conflict with the more formal laws of the state. These customs may relate to corporate etiquette, career patterns, or entertainment expenses, or to such matters as maintaining corporate secrets or making payments to foreign officials. Other forms of private lawmaking may have an even broader range. Recent scholarship maintains that fleeting human encounters do not take place in a legal void, but are governed by culturally determined understandings and customs which cause them to be more rigidly enforced than the laws of the state. ${ }^{9}$

Nevertheless there are still many intellectual obstacles to acknowledging these forms of private lawmaking. Some view private lawmaking as

8. COWAN \& STRICKLAND, supra note 6, at i. Fuller has described informal lawmaking under the rubric of "implicit law," which he distinguishes from "made law"-i.e., a statute passed under the authority of the state. LON L. FULlER, ANATOMY OF LAW 43-49 (1968) [hereinafter FULLER, ANATOMY]. This conceptualization of informal lawmaking may include the rules governing a camping trip of friends, id. at $48-49$, the custom of merchants, id. at 45 , or tribal law, id. at 74-75.

9. Reisman has described microlegal systems that govern encounters on the street, the act of waiting in lines, and communications between subordinates and superiors. See generally Reisman, Lining Up, supra note 6; Reisman, Looking, Staring and Glaring, supra note 6; Reisman, Rapping, supra note 6. It should come as no surprise that related legal dynamics govern both microlegal and macrolegal systems. Both systems try to maximize their efficacy within limits imposed by circumstances such as competing legal systems. 
interference with the autonomy of the individual and as lacking fairness and due process. ${ }^{10}$ Private lawmaking also challenges the authority of the state. The many competing interests that characterize contemporary life inspire apprehension that chaos would ensue if any single group of participants were recognized as having autonomous rulemaking powers, ${ }^{11}$ but that does not mean that such rules no longer exist or have lost their effectiveness. The effectiveness of state-sponsored laws in statute books or appellate court opinions depends in part on how well they incorporate common understandings of private laws and customs. ${ }^{12}$

10. Perceived injustice commonly occurs in microlegal systems such as the family, schools, and the workplace. See Allen Barton \& Saul Mendlovitz, The Experience of Injustice as a Research Problem, 13 J. LEGAL EDUC. 24, 30 (1960). One aspect related by Melitta Schmideberg concerned parent-child relations:

A child may be punished for something which was passed over yesterday and is joked about tomorrow; it is blamed for things its parents do without qualms. Adults usually have some neat explanation at hand to cover up their inconsistent and unjust behavior against which children are helpless. Whenever trouble arises the child is likely to be held responsible, and there are very few adults who would ever admit to a child that they had been in the wrong. Justice between parents and children does not exist because there is no equality, and those in authority are judges in their own cause. The nursery is like a fascist state: a great parade is made of justice but it depends on the good-will of the authorities whether they dispense justice or punish whoever dares to complain.

The fact that men may prefer death to a life without freedom and justice shows how bitterly they must have resented the lack of these in their childhood.

Melitta Schmideberg, On Querulance, 15 PSYCHOANALYTIC Q. 472, 488 (1946). For a critical description of the romantic view of private lawmaking as more just and democratic than any other form of law imposed by a ruler or the state, see FULLER, ANATOMY, supra note 8 , at 70 .

11. Fuller argues against the notion that autonomous private lawmaking necessarily results in chaos. LON L. FULLER, THE MORALITY OF LAW 124-29 (1964) [hereinafter FULLER, MORALITY]. See generally Developments in the Law-Judicial Control of Actions of Private Associations, 76 HARV. L. REV. 983 (1963).

12. Sometimes appellate courts openly admit the significance of private laws and customs, for example when usage (private lawmaking) has supplanted statutory provisions. See, e.g., Spurgeon v. Jamieson Motors, 521 P.2d 924 (Mont. 1974). Usage in the Wisconsin lumber industry played a significant role in the application of contract law. JAMES W. HURST, LAW AND ECONOMIC GROWTH: THE LEGAL HISTORY OF THE LUMBER INDUSTRY IN WISCONSIN 1836-1915, at 290 (1964); see also E. ALLAN FARNSWORTH, CONTRACTS $\$ \$ 7.13-.14$ (1982); FULLER, ANATOMY, supra note 8, at 57-59 (arguing that interpretation acts as a means to adjust "made law" to "implicit law").

With respect to the First Amendment, Ingber maintains that "communal values" should be recognized and protected within institutional settings. Stanley Ingber, Rediscovering the Communal Worth of Individual Rights: The First Amendment in Institutional Contexts, 69 TEx. L. REv. 1, 98-102 (1990). A constitutional document, like any other written enactment, tends to be interpreted and supplemented by an unwritten body of private law. Weyrauch, Basic Law, supra note 6, at 52-53. Indeed, the laws of associations, groups, and institutions have been characterized as a body of unwritten constitutional law that has grown outside of the written constitution. FULLER, MORALITY, supra note 11, at 128-29 (citing Charles E. Wyzanski, The Open Window and the Open Door, 35 CAL. L. REv. 336, $341-45$ (1947)); see also Thomas C. Grey, The Constitution as Scripture, 37 STAN. L. REV. 1 (1984); Thomas C. Grey, Do We Have an Unwritten Constitution?, 27 STAN. L. REV. 703 (1975); Thomas C. Grey, Origins of the Unwritten Constitution: Fundamental Law in American Revolutionary Thought, 30 STAN. L. REV. 843 (1978). Grey's theory of an "unwritten Constitution" appears mostly aspirational, invoking fundamental rights and natural law. The unwritten constitution described in Weyrauch, Basic Law, supra note 6, attempts to reflect reality rather than ideals. This form of unwritten law, although very powerful and to some extent beyond human control, can bring benefits. But it can also discriminate and oppress. 
Mechanical application of the law often creates perceptions of injustice and meets with substantial opposition. ${ }^{13}$ This injustice results when written law lacks the support of unwritten laws and custom. Unwritten rules often have greater vitality and power than the traditional public laws that originate in the cerebral and abstract reasoning of the courts and legislatures. Decisionmakers work under a continuing pressure to incorporate customary rules into their decisions. Such incorporation takes place subtly. For instance, a court's formalistic application of law may be reversed on appeal as an abuse of discretion or a violation of established canons of interpretation. Yet, in their written opinions appellate courts rarely articulate that the basis for their decision rests at least as much on the amorphous body of private law as on public laws. Appellate judges may not even be aware that this is their source of law. ${ }^{14}$

At trial, in appellate courts, and in negotiations, a skillful lawyer avoids referring directly to private lawmaking. Instead an attorney merely hints that his case draws support from private lawmaking, while overtly reasoning in terms of state-made law. Indeed, lawyers' pleas to juries not to leave their common sense at the door can be understood as an appeal to interpret public law in conformity with private law. Lawyers may not be fully aware of this strategy and often credit "experience" for success. ${ }^{15}$ The emphasis of legal education on the state's law makes it unlikely that a lawyer will be conscious of private lawmaking. Nevertheless, a good lawyer instinctively avoids arguing only legal technicalities because doing so often creates the impression that the

13. See, e.g., Dred Scott v. Sandford, 60 U.S. 393 (1856) (using jurisdictional argument to dispose of issue of major national significance, citizenship of African Americans); In re Civil Rights Cases, 109 U.S. 3 (1883); Plessy v. Ferguson, 163 U.S. 537 (1896).

14. Most appellate courts do not explicitly recognize private lawmaking as such and are not conscious of its underlying dynamics. But see Marvin v. Marvin, 557 P.2d 106, 109 n.1 (Cal. 1976) (recognizing that eightfold increase in nonmarital cohabitation called for decisive statement of law on this subject). Furthermore, private lawmaking has even greater influence in nonlitigative contexts, such as negotiations, and in the lower courts, especially when appeals are unlikely. Although empirical evidence is rare, many lawyers attest that trial judges adhere to precedent and statutory authority loosely and essentially dispose of cases according to inarticulate standards and hunches which reflect an immense and amorphous body of informal law. See, e.g., KARL LLEWELLYN, THE CASE LAW SYSTEM IN AMERICA 78-80 (Paul Gewirtz ed. \& Michael Ansaldi trans., 1989); Joseph C. Hutcheson, The Judgment Intuitive: The Function of the "Hunch" in Judicial Decision, 14 CORNELL L.Q. 274, 286-88 (1929); Willard M. McEwen, What Is Never in the Record but Always in the Case, 8 ILL. L. REV. 594 (1914).

Arzt has queried:

Quite generally one may ask, according to what rules do we conduct ourselves, because we normally do not consult the written law beforehand.... We are controlled in vast areas by reason, decency .... and conformity. The latter functions differently in small groups, such as a faculty, than in larger settings. Viewed this way, perhaps the difference between oral and written concretization [of law] disappears?!

Letter from Gunther Arzt, Professor, University of Bern, Swizzerland, to Walter O. Weyrauch, translated from German (Jan. 26, 1993) (on file with authors). The broad definition of law proposed by Cowan and Strickland, supra text accompanying note 8 , may encompass some aspects of the phenomenon described by Arzt.

15. JEROME FRANK, LAW AND THE MODERN MIND 111 n.2 (1970) ("All successful lawyers are more or less consciously aware of this technique. But they seldom avow it even to themselves."). 
case is weak. Lawyers instead stress social context, communal values, and public policies, which are often veiled references to private forms of lawmaking. This Article argues that private lawmaking often prevails over state law in direct conflicts between the two. ${ }^{16}$

In practice, private lawmaking pervasively influences the legal process. The sensitivity of lawyers and policymakers to private social norms often determines whether legislation is effective, whether cases are won or lost, or whether a legal argument is persuasive. Yet, legal theory and practice generally ignore this vast body of law. Bar examinations concentrate on traditional laws of the state, which, in their literal form, have only limited practical significance. Such an approach underestimates the importance of private law. Although lawyers do acknowledge the existence of private law rules, they dismiss them as rules of expediency rather than accept them as coherent systems. ${ }^{17}$

These views treat the most important part of the legal process as purely a matter of common experience that is inevitably subservient to officially sanctioned laws. Law is divided into two spheres, the conscious laws of the state and the unconscious private laws, which are in fact substantially more important. If scholars can sensitize people to the pivotal role of private lawmaking by exposing its basic dynamics, legal theory will present a more accurate picture of legal reality. The dichotomy between the law in the books and the law in action, ${ }^{18}$ the latter of which is based mostly on private lawmaking, would disappear.

16. See Walter O. Weyrauch et al., The Family as a Small Group, in GRoup DYNAMIC LAW: EXPOSITION AND PRACTICE supra note 6, at 153, 156 [hereinafter Weyrauch, Family], where the following partly overlapping hypotheses are developed in detail. First, informal lawmaking has more vitality than the traditional law of the state. Second, in a clash between traditional state law and informal private law, the latter is likely to prevail. Third, legal characterizations are likely to be of little effect, unless supported by informal private law. Fourth, a result supported exclusively by the law of the state is likely to be perceived as inhumane and unjust. Fifth, an argument is likely to be persuasive if it can be supported by both the law of the state and informal private law. Sixth, discretionary decisions are likely to be based on informal private law. Seventh, discretionary decisions that violate the norms of private lawmaking are prone to be reversed on appeal. Eighth, legal counseling and planning must take account of informal law. For illustrations, see infra text accompanying notes 243-54, 266-69. In a conflict between the laws of the state and "folk norms" in negotiations, the latter tend to govern. Herbert Jacob, The Elusive Shadow of the Law, 26 LAW \& SOC'Y REV. 565, 566-67 (1992).

17. See Walter O. Weyrauch \& Sanford N. KaTZ, American Family LaW IN TRANSITION 50708 (1983) (discussing unwritten standards in adjudication of child custody disputes which deal with sexual taboos that "cannot be openly acknowledged"); see also Boroff v. Boroff, 250 N.W.2d 613, 617-18 (Neb. 1977) (noting trial court's improper refusal to award custody of twelve-year-old daughter to her divorced father because she should "get up to her maturity with the mother"); infra note 243.

18. See EHRLICH, supra note 5, at 486-506 (discussing need for study of "living law" in addition to "legal propositions"); Roscoe Pound, Law in Books and Law in Action, 44 AM. L. Rev. 12 (1910) (discussing relationship between public thought, feeling, and law in action). 


\section{B. Fostering Respect for Private Lawmaking}

\section{Parallels Between Private Lawmaking and Tribal Law}

This Article uses an intensive study of tribal laws ${ }^{19}$ to illustrate how scholars can increase awareness of private lawmaking. ${ }^{20}$ There are important parallels between legal cultures based on oral traditions and the unwritten laws within institutions such as courts, corporations, and university faculties. ${ }^{21}$ In addition to the practical importance of these forms of lawmaking, legal scholars should not overlook the relevance of private law to theory. "Tribal" aspects of private law illuminate larger issues. This Article does not maintain that contemporary institutions, such as law firms, ${ }^{22}$ legislative committees, ${ }^{23}$ juries and appellate courts, ${ }^{24}$ university faculties, ${ }^{25}$ corporations, ${ }^{26}$ or

19. For the purposes of this Article, "tribal law" means the norms of a homogeneous ethnic group, mostly based on oral tradition and supported by communal sanctions, which aim to regulate life and promote the common good. The use of the terms "tribe" or "tribal" does not impute any sense of primitiveness. The terms are useful for the limited purposes of this Article because they demonstrate that our law has numerous characteristics that also could be called tribal. These elements of our legal system lend themselves to comparisons with the laws of the Roma, as will become increasingly apparent as this Article progresses. But see the references to "primitive law" in E. ADAMSON HOEBEL, THE LAW OF PRimitive MaN 18-28 (1954); Karl. L. LlewEllyn \& E. ADAMSON HoEbel, The CheyenNe Way: CONFLICT AND CASE LAW IN PRIMITIVE JURISPRUDENCE 41-63 (1941).

20. In his comparative law classes Weyrauch found that students were persistently more interested in tribal law than in the laws of western Europe. The materials included, among others, HoEBEL, supra note 19, at 67-99 (discussing legal norms of "Eskimo" villages); JOHAN HUIZINGA, HOMO LUDENS: A STUDY OF THE PLAY ELEMENT IN CULTURE 84-86 (1950) (discussing legal culture of Inuit); and J.F. Holleman, Disparities and Uncertainties in African Law and Judicial Authority: A Rhodesian Case Study, 17 AFR. L. STUD. 1 (1979). The Holleman article has significant contemporary relevance. Holleman describes the effects of a conflict between colonial law and preexisting tribal norms. As faith in the existing tribal legal order was undermined, violent forms of self-help emerged that outwardly invoked earlier law. The resulting social disorder was combined with excessive demands for redress. Although the article is confined to African tribal history, the parallels to American urban riots are evident. Compare Holleman, supra, with reports of the Los Angeles riots in May 1992 following the Rodney King verdicts. See, e.g., Understanding the Riots Part I: The Path to Fury, L.A. TIMES, May 11, 1992, at T-1. See also reports of the Miami riots in May 1980, occurring after an all-white jury acquitted four white policemen who had beaten a black motorist to death. See, e.g., BruCE Porter \& Marvin DunN. THE Miami Riots of 1980: Crossing THE BoundS (1984), reviewed by Anthony Chase, In the Jungle of Cities, 84 MiCH. L. REv. 737, 751-59 (1986).

21. See sources cited supra note 6 .

22. See generally Walter O. Weyrauch, An Anthropological Study of the Legal Profession: Enwin O. Smigel, The Wall Street Lawyer, 113 U. PA. L. REV. 478 (1965) (book review) [hereinafter Weyrauch, Legal Profession].

23. The Clarence Thomas Senate confirmation hearings, in particular the televised hearings before the Senate Judiciary Committee involving Anita Hill, resembled a tribal court in numerous respects: (1) The adjudicators were all male; (2) the standards applied were based on oral tradition; (3) no clear distinctions between facts and opinion were maintained; (4) no distinctions between procedure and substance were observable; (5) standards of relevance tended to be interpreted in the widest possible sense; (6) no exclusionary rules of evidence were applied; (7) the adjudicators and witnesses played to the wider audience; (8) the audience, although not physically present, played a major role in the adjudication, in that the presumed reaction of the audience affected all participants. Cf. Holleman, supra note 20, at 5-9 (characterizing tribal adjudication); see also Dennis E. Curtis, The Fake Trial, 65 S. CAL. L. REV. 1523 (1992) (analysis of Thomas/Hill hearings).

24. With respect to courts, see generally Walter F. Murphy, Courts as Small Groups, 79 HARV. L. REv. 1565 (1966); Eloise C. Snyder, The Supreme Court as a Small Group, 36 Soc. FoRCES 232 (1958). 
families, ${ }^{27}$ are "tribal," but merely suggests that they share characteristics with societies that are commonly referred to as tribes. There are close analogies between tribal lawmaking and informal private law in our daily lives. Thus, if we understand tribal law, we can better comprehend the operation of our own legal system.

The analysis in this Article focuses on a tribal system that is operating autonomously within our society, largely unnoticed: the internal laws and procedures of the population known as "Gypsies." Perhaps the term "nation" would be more appropriate for Gypsies than "tribe,"28 although the Gypsies lack many features usually attributed to nations, such as common territory and centralized government. The Gypsies do share, however, a common identity and ethnic origin, a common language, and an identifiable culture. A legal system of common basic characteristics also exists, even though it may differ in some respects among various ethnic subdivisions of the Roma.

\section{Reasons for Selecting Gypsy Law}

This Article focuses on the Roma because the conspicuous absence of legal scholarship on their laws and courts, amidst an otherwise vast body of literature, demonstrates that the academy is oblivious to the existence of embedded autonomous legal systems. The very idea that an autonomous, cohesive society with its own language and legal system exists in the United States (and elsewhere) surprises most theorists, and highlights the extent to which Gypsies have successfully maintained their invisibility within a larger host society. ${ }^{29}$ Traditional legal scholarship presumes that different regionally

With respect to juries, see generally Mortimer R. Kadish \& Sanford H. Kadish, The Institutionalization of Confict: Jury Acquittals, 27 J. Soc. IssuEs 199 (1971); Fred L. Strodtbeck \& L. Harmon Hook, The Social Dimensions of a Twelve-Man Jury Table, 24 SOCIOMETRY 397 (1961).

25. See generally William L. Richard, Note, Faculty Regulations of American Law Schools (A Survey), 13 CLEV.-MARShall L. REV. 581 (1964).

26. For a discussion of legal and sociological approaches to various such groups, see generally Joseph Taubman, Law and Sociology in the Control of Small Groups, 13 U. TORONTO L. REV. 23 (1959).

27. See generally Herma H. Kay, The Family and Kinship System of Illegitimate Children in California Law, 67(6) AM. ANTHROPOLOGIST 57 (1965); Weyrauch, Family, supra note 16.

28. The Romani Union, an international organization located in Hamburg, Germany, links national Gypsy organizations and has consultative status within the Economic and Social Council of the United Nations. The consultative status enables the Romani Union to speak as a nongovernmental organization at Economic and Social Council meetings. List of Non-Governmental Organizations in Consultative Status with the Economic and Social Council in 1989: Note by the Secretary General, U.N. ESCOR E/1989/INF/11 (1989); see also ANGUS FRASER, THE GYPSIES 315-18 (1992).

In the United States, Gypsies have been recognized as a distinctive ethnic group deserving protection under antidiscrimination law. Saint Francis College v. Al-Khazraji, 481 U.S. 604, 612 (1987) (dictum by Justice White referring to Gypsies in suit brought by person of Arab descent); Janko v. Illinois State Toll Highway Auth., 704 F. Supp. 1531 (N.D. Ill. 1989) (ruling in favor of Gypsy plaintiff in Title VII employment discrimination suit, relying on Saint Francis College).

29. Cf. HANCOCK, PARIAH SYNDROME, supra note 1, at 130 (noting that American Gypsies have learned to hide their identity in order to avoid discrimination); ANNE SUTHERLAND, GYPSIES: THE HIDDEN AMERICANS 290 (Reissue 1986) (1975) (commenting that most non-Gypsies are ignorant of or doubt the existence of Gypsies in United States); Albert W. Vogel, The Least Known Minority, Crv. RTs. DiG., Fall 
identifiable legal systems may coexist and be compared. They may also conflict with each other; the ornate doctrine of conflict of laws has been developed to resolve these clashes. Yet, legal scholars have consistently failed to acknowledge the possibility that our legal system is permeated by other autonomous legal systems. These coexisting autonomous legal systems are fundamentally "foreign" to the laws of the state, and the study of those systems remains foreign to much of current legal scholarship. ${ }^{30}$

This Article resists examining a more remote tribal society, because distance in time and space encourages detachment. The Gypsies living among us help reinforce the thesis that autonomous private legal systems have a pervasive influence on daily life. Indeed, the Romani legal system coexists with the host legal order wherever Gypsies are present. Legal and political theories, because they concentrate on the laws of the state, have limited intellectual apparatus with which to recognize such coexisting legal systems. A broader conception of law is necessary to account for the flow of "tribal" law that emanates from associations, groups, and institutions.

\section{IMPEDIMENTS TO RESEARCH ON GYPSY LAW}

\section{A. Impact of Terminology}

The terminology used by non-Gypsies to describe the Romani people reflects hidden value judgments. The term "Gypsy" as used in scholarly writings and encyclopedias supports misconceptions that all Gypsies are migratory, roam the countryside, and are engaged in questionable or illegal activities, as exemplified by slang terms like "to gyp" (meaning to swindle) and "gyp joints." 31 It is only natural that many Roma, therefore, view the

1978, at 35; see also RONALD LEE, GODDAM GYPSY 9 (1971) [hereinafter LEE, AUTOBIOGRAPHY] ("The greatest strength of the Gypsies is their invisibility. It is not without good reason that many people consider them to be extinct, for the Roms themselves do everything in their power to perpetuate the myth of their non-existence.").

30. Some authors, whose work is more related to the social sciences than to traditional legal research, have commented upon the manner in which legally distinct subgroups may interact with a larger, enveloping society. POSPISIL, ANTHROPOLOGY OF LAW, supra note 6, at 97-126, referring with qualifications to EHRLICH, supra note 5, at 24, 36-38; LLEWELLYN \& HOEBEL, supra note 19, at 27-28; MAX WEBER ON LAW IN ECONOMY AND SOCIETY 17 (Max Rheinstein ed. \& Edward Shils \& Max Rheinstein trans., 1969); Laura Nader \& Duane Metzger, Conflict Resolution in Two Mexican Communities, 65 AM. ANTHROPOLOGIST 584 (1963); see also LEOPOLD POSPISIL, THE ETHNOLOGY OF LAW 54 (2d. ed. 1978) ("[T]here are in a society as many legal systems as there are functioning subgroups."); Weyrauch, Basic Law, supra note 6, at 49 ("Law can be viewed as a network of small group interaction. Basic characteristics of legal systems govern the interaction and permeate each individual small group."). In the Middle Ages the Gypsies were recognized as an imperium in imperio, with jurisdiction over their own affairs. FRASER, supra note 28, at 127.

31. WEBSTER'S THIRD NEW INTERNATIONAL DICTIONARY 1015, col. 3 (unabr. ed. 1986) (hereinafter, WEBSTER'S THIRD]. There is a corresponding slang term among American Roma, to "get gadged," meaning to be cheated by non-Gypsies (gaje). Notes by Ian F. Hancock, Professor of English and Linguistics at the University of Texas, Austin, on manuscript draft of this Article (Jan. 1993) at $6 \mathrm{n} .69$ (on file with authors) [hereinafter Hancock, Notes]. 
word "Gypsy" as offensive. The term also perpetuates the misconception that the people originated in Egypt. In French, bohemien and tsigane, and in German, Zigeuner, have similar meanings and connotations. Like "Gypsy," these terms reinforce incorrect perceptions that the Gypsies originally came from Bohemia (or in the case of tsigane, from Phrygia in Asia Minor and Thrace). ${ }^{32}$ The term "Sinti" refers to a part of the Gypsy population that resides mainly in Germany. ${ }^{33}$ To attach universal meaning to the word "Gypsy" is inappropriate.

Nevertheless, non-Gypsies (gaje) use the term "Gypsy" to describe all Romani people and their descendants, who are believed to have left northern India about a thousand years ago. ${ }^{34}$ Despite the generic label "Gypsy," the Romani people actually comprise many different groups bound together by notions of purity and pollution, and by Gypsy law. The research that forms the basis for this Article deals overwhelmingly with Vlax Gypsies from Wallachia, Rumania - in particular, the Mačvaya, Kalderasha, and Lovara. The Vlax are the largest identifiable group of Gypsies in the United States, although precise estimates of the size of their population are elusive. Because the Romanichals, Bashalde, and Sinti have quite different customs, in spite of cultural similarities, academic literature neglects them. ${ }^{35}$ Therefore, unavoidably, so does this Article. ${ }^{36}$

The literature's ignorance of Romani terminology parallels the legal scholarship's ignorance of Romani law. The Gypsies call themselves "Roma" (singular "Rom"), meaning man or husband, but this word is little known outside Gypsy communities. ${ }^{37}$ Its similarity to "Romania," especially in the adjectival form "Romani," leads to the misconception that Gypsies and

32. Yoors, Americana, supra note 1, at 647 (referring to Michael J. de Goeje and Franz von Miklošic).

33. WAlter O. Weyrauch, Gestapo V-LeUTE 66 (1989); see also Reimer Gronemeyer \& Georgia A. RAKELMANN, Die Zigeuner: Reisende IN EuROPA 9-11 (1988). The designation as "Sinti" probably originates from the German word Zinn (tin). Hancock, Notes, supra note 31, at 2 n.13. This word likely originated at a time when many German Gypsies worked as tinsmiths.

34. See supra note 1 (terminology); infra note 57 and accompanying text (history and migrations).

35. See Thomas Acton, Academic Success and Political Failure: A Review of Modern Social Science Writing in English on Gypsies, 2 ETHNIC \& RACIAL STUD. 231, 234-35 (1979); see also Ian F. Hancock, Gypsies in the United States, 8 ETHNIC F., 72, $73-75$ (1988) (reviewing MARLENE SwAY, FAMILIAR STRANGERS: GYPSY LIFE IN AMERICA 6-13 (1988)) [hereinafter Hancock, Review]. Anthropologists in particular have mistakenly assumed that Kalderash informants, belonging to the Vlax group, have informed on customs that apply to all American Gypsies. These misconceptions are so frequent that Acton has coined the term "Kalderashocentric." Acton, supra at 234-36.

Although the name "Vlax" comes from "Wallachia," many modern Vlax populations do not identify with that region in Rumania, but with an intermediate country or location to which they migrated at a later time. For example, the Mačvaya mention a Serbian town, Mačva, as theirs. Hancock, Notes, supra note 31, at $1 \mathrm{n} .12$. The spelling of names of different Romani ethnic groups, such as the Mačvaya, varies. We have followed the spellings suggested by Hancock, although cited authors may have used different spellings.

36. The reader is therefore cautioned against making generalizations about all Gypsies based on the information presented here.

37. At the First World Romani Congress in 1971, the delegates adopted the term "Roma" as a collective name for all Gypsies. FRASER, supra note 28, at 316. 
Rumanians are identical or related. Words of Gypsy origin, descended from Sanskrit sources, are essentially unknown among non-Gypsies. Even the growing literature of Gypsy scholars uses the term "Gypsies" interchangeably with "Roma" due to the non-Gypsy world's ignorance of the Romani language.

These misconceptions about the Roma can result in confusion among nonGypsy authors. The deeply ingrained notion that all Gypsies are nomadic overlooks the fact that the Vlax in Wallachia and Moldavia (which are now parts of Rumania and Moldova) were enslaved until 1856. Indeed, the Vlax were bound to their owners' homes and farms for about five hundred years. ${ }^{38}$ Among the Vlax, the forced sedentary life of serfdom seems to have preserved internal Gypsy law and strengthened the culture as a whole, although some of their cultural characteristics probably were acquired from the host population. ${ }^{39}$ The large-scale migration of the descendants of these Gypsies to the United States may have revived ancient nomadic patterns only to the extent necessary to avoid local hostility.

\section{B. Impact of Past Persecution}

Negative characterizations of the Romani people create corresponding problems in research efforts, especially those concerning Gypsy law. Most literature on Gypsies has been produced by non-Gypsy scholars who relied on the writings of other non-Gypsies and ultimately on Gypsy informants. ${ }^{40}$ The Gypsies' views, and their responses to scholarly inquiries, reflect a long and continuing history of suffering and worldwide persecution, including the murder of an unknown number of Gypsies in Nazi concentration camps. ${ }^{41}$

38. See FRASER, supra note 28, at 57-59; Ian F. Hancock, The Romani Diaspora Part One, 1989 WORLD \& I 612, 617 [hereinafter Hancock, Diaspora I].

39. Hancock, Diaspora I, supra note 38 , at 617 .

40. See Acton, supra note 35, at 234-37; HANCOCK, PARIAH SYNDROME, supra note 1, at 125-27.

41. Estimates of the number of Gypsies who fell victim to the Nazis vary because not all Roma were brought to concentration camps. Some were shot or hanged as partisans at the Russian front, while others were summarily executed as "asocials." Moreover, classifications within concentration camps were not uniform. While Kogon posits that only an "insignificant remnant" of the Romani population survived the Holocaust, Eugen Kogon, THE THEORY AND PRACTICE of Hell: THE GERMAN ConCENTRATION CAMPS AND THE SYSTEM BEHIND THEM 39 (Heinz Norden trans., 1950), Döhring suggests that 20-45\% of the German Gypsy population died as a result of the Holocaust. HANS J. DöHRING, DIE ZIGEUNER IM NATIONALSOZIALISTISCHEN STAAT 191-92 (1964). Estimates of a million Gypsies killed are probably too conservative. See Ian Hancock, "Uniqueness" of the Victints: Gypsies, Jews and the Holocaust, 1988 WITHOUT PREJUdICE: EAFORD INT'L REV. RACIAL DISCRIMINATION 45, $55-56$ [hereinafter Hancock, Holocaust]. But cf. Yoors, AMERICANA, supra note 1, at 647; ULRICH KÖNIG, SINTI UND ROMA UNTER DEM NATIONALSOZIALISMUS: VERFOLGUNG UND WIDERSTAND $87-88$ (1989) (estimating over 500,000 killed).

The attitude of the German population toward Gypsies continues to be overwhelmingly negative. A poll taken in the 1960's in a city outside of which a Gypsy camp had long existed indicated that of 200 respondents, 180 expressed hostile sentiments. Luc Jochimsen, Zigeuner hierzulande, in MINDERHEITEN IN DER BUNDESREPUBLIK 21, 49 (Bernhard Doerdelmann ed., 1969). German news reports, while critical of xenophobia, tend to be ambivalent toward Gypsies, especially those who have recently arrived from other countries. See, e.g., Ariane Barth, "Hier steigt eine Giftsuppe auf," DER SPIEGEL, Oct. 14, 1991, at 118; Sabine Rückert \& Michael Schwelien, Die Zigeuner sind da!, DIE ZEIT, Sept. 25, 1992, at 11. For responses from the United States, see, for example, Andrei Codrescu, Gypsy Tragedy, German Amnesia, 
Fearing further persecution, the Gypsies are inclined to distrust all non-Gypsies.

Tellingly, the Gypsies use the term gaje to refer to all non-Romani people without differentiating among them. Gaje has pejorative connotations. It originally meant peasants, or uncivilized and uneducated persons, but it had connotations comparable to "barbarians" in English. In contemporary usage, gaje has a more neutral meaning: "non-Gypsy." 42 The gaje (singular gajo) are subject to ridicule and disdain because, from a Gypsy perspective, they do not conform to norms of proper behavior. The Gypsies generally view the gaje as having no sense of justice or decency. Even behavior that is "law-abiding" by gajikane $^{43}$ standards can be considered inherently indecent. Furthermore, not only do the Gypsies consider non-Gypsies polluted, they also believe that Gypsy names and rituals lose their magical effectiveness if uttered to gaje. ${ }^{44}$ Consequently, the Gypsies believe they should approach and respond to the gaje with caution, ${ }^{45}$ especially if the gaje profess good intentions, claim to

N.Y. TIMES, Sept. 23, 1992, at A27 (criticizing Germany's policy of repatriating Roma to Rumania); Marc Fisher, Germany's Gypsy Question: Haunting Echoes as a Hated Minority Gets "Retransferred," WASH. POST, Nov. 1, 1992, at F1 [hereinafter Fisher, Germany's Gypsies]; Carol J. Williams, For Gypsies, No Place To Call Home. Ethnic Tension: The Refugees Being Repatriated from Germany Face an Unfriendly Reception in Romania, L.A. TiMES, Oct. 12, 1992, at A8. A recent German constitutional revision has severely restricted asylum rights. GRUNDGESETZ [Constitution] [GG] art. 16a (Germany). The revision, although couched in general language, primarily applies to Gypsy refugees from Eastern Europe. Stephen Kinzer, Bonn Parliament Votes Sharp Curb on Asylum Seekers, N.Y. TiMES, May 27, 1993, at A1, A4 ("More than half of the foreigners now arriving in Germany in search of asylum are from Rumania and Bulgaria, and most of them are Gypsies."); see also supra note 2. For an exhaustive treatment of German law relating to Gypsies, see Michael M. Jansen, Sinti and Roma: An Ethnic Minority in Germany, in THE PROTECTION OF ETHNIC AND LINGUISTIC MINORITIES IN EUROPE 167 (John Packer \& Kristian Myntti eds., 1993). Concerns have been expressed that recent German legislation is specifically aimed at repatriating Gypsy refugees to Rumania. Id. at 182.

42. See GRONEMEYER \& RAKELMANN, supra note 33, at 9 (defining gaje as peasants, fools); JAN YOORS, THE GYPSIES 16 (1967) [hereinafter YOORS, GYPSIES] ("All non-Gypsies or outsiders are called 'Gaje,' which he translated as 'peasants.' He looked me in the eyes as he said it, but there was a slight hesitation in his voice and I sensed the pejorative connotation.") (footnote omitted). According to Hancock the term gaje refers to male non-Gypsies. HANCOCK, PARIAH SYNDROME, supra note 1, at 137. Hancock asserts that the term is not necessarily pejorative. However, the context in which the word is used and the intonation may result in a negative meaning. Following Hancock who stresses the essentially neutral contemporary meaning of gaje, this Article uses the term interchangeably with the term "non-Gypsy." This interchangeable use helps to effect the incorporation of a Romani perspective into the Article. It corresponds to the interchangeable use of the term "Gypsy" (which also may have pejorative connotations) with the term "Roma." See supra note 1. Absolute neutrality, unfortunately, is not possible because the linguistic means to express it are inherently flawed. $C f$. Walter O. Weyrauch, Limits of Perception: Reader Response to Hitler's Justice, 40 AM. J. CoMP. L. 237, 251-54 (1992) (discussing reader-response school of literary theory). Some authors capitalize the term gaje. We have consistently used capital letters for Rom and Gypsy, but not for gaje. The latter term is all-encompassing and does not refer to any distinct ethnic group or nationality.

43. Gajikano is the singular adjectival form of gaje. The plural adjectival form is gajikane. We are indebted to Ian Hancock for this clarification; see also IAN HANCOCK, NOTES ON ROMANI GRAMMAR 15-16 (4th ed. 1992).

44. Martin Block, Gypsies 13 (1939); Jean-Paul Clébert, The Gypsies 132 (Charles Duff trans., 1963) (describing "secular taboo" that prevents disclosure of religious ritual to non-Gypsy world).

45. See SUTHERLAND, supra note 29, at 21 (describing how author encountered vehement cursing, feigned imbecility, pretense of mental retardation, polite imperviousness, alleged deafness and blindness, mocking lies, and panic in response to tape recording); Vogel, supra note 29, at 36 (noting extreme 
serve the best interest of the Gypsies, or propagate some abstract ideals of non-Gypsy origin, such as the scholarly pursuit of truth. Romani reservations apply equally to gajikane notions of due process, civil rights, and neutrality of law.

As a result of such reservations, persons inquiring into the operation of the Gypsy legal system cannot count on cooperation. Distortions of reality are inevitable and they permeate almost every aspect of non-Gypsy scholarship on the Gypsies. As a further impediment to accuracy in studies of the Gypsies, gajikane scholars have failed to wrestle with their own deeply ingrained beliefs in the superiority of their cultural values, including the notions that objective scholarship and science are possible and that some neutral concept of merit ${ }^{46}$ can determine the value of other cultures. Gajikane scholars implicitly and paradoxically assume that gajikane standards of measurement are useful in evaluating the Gypsy culture. Scholars do not characterize themselves as non-Gypsy; indeed, there is no corresponding word for gaje in our vocabulary. Yet other cultures that have experienced persecution or that are insular have words corresponding to the Gypsy term gaje, such as goyim for everyone who is not a Jew and haole for all non-Hawaiians. All these terms share disparaging connotations and reflect barriers to communication. ${ }^{47}$ Thus widespread failure to confront the difficulties of gajikane scholars studying Gypsies has resulted in a subtle yet pervasive cultural insensitivity in most literature on the Gypsies.

suspicion against any form of structured questioning). The evasionary strategies of Gypsies toward non-Gypsies are ingenious. Yoors reports veiled ridicule, seeming childlike admiration, and an endless stream of questions meant to induce the non-Gypsies to reply rather than ask questions themselves. If questions cannot be avoided, multiple inconsistent answers might be given. Gypsies may start scratching themselves persistently, implying the presence of vermin or they may cough violently suggesting a contagious lung ailment. YOORS, GYPSIES, supra note 42, at 50-51.

46. The concept of merit is essentially culturally determined. One of the coauthors has defined merit as the "ability to act 'responsibly' and to fit and operate well within an existing institutional framework." Walter O. Weyrauch, Governance Within Institutions, 22 STAN. L. REV. 141, 151 (1969) [hereinafter Weyrauch, Governance]. It tends inevitably to disadvantage some ethnic minorities, such as Gypsies, because they adhere to values different from those of the ruling majority who determine institutional frameworks. From that perspective, the traditional educational process can indeed damage cultural identity. See infra note 204. Whether Gypsy children who have been forced into the gajikano educational system are capable of exercising genuine choice to remain with the Romani people or go elsewhere, is at least subject to debate. But see W. Michael Reisman, Autonomy, Interdependence, and Responsibility, 103 YALE L.J. 401, 416-17 (1993) [hereinafter Reisman, Comment]. No doubt, the Romani people are now better off in the United States than in many other countries, but the American liberal democratic state is in some respects aspirational and, in spite of major progress in the last decades, not fully realized, particularly in areas of race relations.

47. LEO ROSTEN, THE JOYS OF YIDDISH 141-42 (1968) (defining goy: "1. A Gentile, i.e., anyone who is not a Jew. . . 2. Someone who is dull, insensitive, heartless."); WeBSTER's THIRD, supra note 31, at 1030 (defining haole: "one who is not a member of the native race of Hawaii; esp: a member of the white race"). 


\section{A Suggested Method for the Study of Gypsy Law}

To some extent, this Article faces the same problems as other scholarship by non-Gypsy authors. Partially to offset any hidden bias, this Article tries to recognize the perspectives that the Romani people have about themselves and about non-Gypsies. Although these standards undoubtedly reflect the Gypsies' own ethnocentrism, they nevertheless articulate viewpoints often neglected in non-Gypsy scholarship. If this creates an appearance that we are overly sympathetic to the Gypsies, the basic purpose of our presentation should be kept in mind. It is less focused on solving the social problems that may result from the steadfast refusal of an ethnic people to be assimilated and more concerned with gaining insight into the workings of customary oral traditions in law, including our own.

Any study of the internal laws of the Gypsies must inevitably reflect the research difficulties associated with studying Gypsies generally. Not only is it incorrect to project the legal customs of some Gypsies onto the whole population, but the memory of severe persecution may affect the willingness of Gypsies to share confidential information on their law. To the Gypsies, the purity of their law plays a crucial role in maintaining cultural identity and integrity against an onslaught of foreign cultural influences that may be well-motivated, but often are of doubtful value, if not destructive. ${ }^{48}$ While these impediments to the study of Gypsy law leave unanswered numerous questions, traditional scholarship on Gypsies nevertheless has value because it does provide some accurate and detailed information which is otherwise unavailable to non-Gypsies and points to fruitful areas for further research. The writings of Gypsy authors also have value in that they demonstrate that many stereotypes of Romani culture may be unfounded. To the extent that existing uncertainties affect this Article, cautionary signals alert the reader that our presentation, especially with regard to the particularities of Gypsy law, is not meant to be conclusive.

The research method employed here is similar to the one Thomas Acton employed ${ }^{49}$ Many case studies of Gypsies already exist. Typically these studies focus on a small group of Gypsies and then make generalizations about all Gypsies. Thus, Acton argued that another such project would add little to the state of knowledge on Gypsies; instead he favored a synthesis of the

48. Sutherland suggests that the concepts of religion, tradition, and law, as embodied in the term of romaniya, are interrelated. Accordingly, a person's identification as a Rom appears to depend on the unquestioning acceptance of these spiritual values rather than on external factors, such as ethnic origin. SUTHERLAND, supra note 29, at 17-18, 29.

Sutherland reports also in the new preface to her book, reissued in 1986, that the scholarly information in the earlier 1975 edition was misused by the police to prosecute Gypsies. ANNE Sutherland, The Hidden AMERICANS, at xii (Waveland Press, Inc. 1986) (1975).

49. Thomas A. Acton, Gypsy Politics AND Social Change 2-3 (1974). Acton argues that even inconsistent or inaccurate existing studies could be useful if supplemented by his own field research. 
existing data. Although he rarely quoted it in his work, Acton used his field research primarily as an aid to analyze the existing literature. ${ }^{50}$ Similarly, this Article uses the emerging literature of Romani scholars for critical insights into the writings of gajikane authors.

\section{GYPSY LAW ${ }^{51}$}

An important goal of this Article is to demonstrate that the Gypsy legal system not only protects the Gypsies from external and internal threats, but also serves as a code that organizes Gypsy society. In particular, Gypsy law has evolved to insulate Gypsies from the host society, and thus to maintain its own insularity from the host legal system.

\section{A. Historical Origins and Ethnic Setting}

There are anywhere from three to fifteen million Gypsies living in forty countries today. ${ }^{52}$ Although research in linguistics suggests a common Indian source, the origins of the Gypsy people remain unclear because their history is largely unrecorded. Some social scientists attribute this lack of recorded history to the high rate of illiteracy among the Gypsies. Interestingly, Gypsy illiteracy may have been purposeful. ${ }^{53}$ Gypsies share a fervent belief in their own uniqueness, and ethnocentricity has kept them from violating their prohibition against cultural integration. Likewise, myths surrounding the Gypsies and their origins might have been a matter of faith, or perhaps were devised to mislead non-Gypsies, and thus to support their own cultural

50. Id. at 3 .

51. This discussion of Gypsy law deals primarily with Vlax Gypsies of Rumanian origin, the largest identifiable group of Roma in the United States. Other Gypsies, such as the Romanichals from northern Europe and the British Isles, adhere to similar notions of purity and pollution, but have less formalized procedures. See Ronald Lee, The Kris Romani, RomA, July 1987, at 19, 19-20 [hereinafter Lee, Kris].

Much of the factual information is based on the works of authors such as Jean-Paul Clebert, Rena C. Gropper, Ian Hancock, Ronald Lee, Jean-Pierre Liegeois, John B. McLaughlin, Carol J. Miller, Judith Okely, Matt T. Salo, Sheila M. Salo, Carol Silverman, Anne Sutherland, Marlene Sway, Carl-Herman Tillhagen, Elwood B. Trigg, and Jan Yoors, as cited in this Part. Because of the multitude of detailed facts and parallel observations, for example, on marime and the kris, references have been grouped together and all relevant references may not be given in each individual instance.

52. World estimates vary significantly and are highly unreliable. See, e.g., JEAN-PIERRE LIÉGEOIS, GYPSIES: AN ILLUSTRATED HISTORY $45-46$ (1986) (12-15 million); MARLENE SWAY, FAMILIAR STRANGERS: GYPSY LIFE IN AMERICA 6 (1988) (8-10 million); Mary Lou Fulton, 'King of the Gypsies' Seeks New Image for His People, L.A. TIMES, May 28, 1989, \& 2, at 1 (3-5 million). Liegeois suggests that political motives, and the dominant populace's attitude toward the Romani population, have led to denials, underestimates, and even exaggerations of statistical census data. LiÉGEOIS, supra, at 45. Equally important is the desire of the Roma to protect themselves by concealing ethnicity from a dominant, hostile host country. Hancock estimated the American Romani population at between 750,000 and 1,000,000. Hancock, Diaspora I, supra note 38 , at 613 . The true figure may be higher than any of the estimates because of the traditionally high birthrate of Gypsies. The U.S. Census figure of about 1,600 Gypsies in the United States for 1980 is absurdly low. See id.; Yoors, AMERICANA, supra note 1, at 650.

53. See CLÉBERT, supra note 44, at 132-33; see also infra notes 192, 203-04 and accompanying text. 
insularity ${ }^{54} \mathrm{~A}$ history of persecution has further reinforced this isolationism. As a result of suspicion and hostility, countries in western and central Europe have tried for centuries to rid themselves of the Roma. State-sponsored discriminatory measures have included forced assimilation and slavery, as well as the systematic murder of Gypsies in Nazi concentration camps. ${ }^{55}$ In spite of this persecution, or perhaps because of it, Gypsies have succeeded remarkably in retaining their cultural identity, often by engaging in the migratory behavior characteristic of the nomads of Asia. ${ }^{56}$

The precise reasons why the Roma left their homeland remain uncertain. Current research suggests that the Roma are descendants of the Dravidians who inhabited India before the arrival of Indo-European populations. They appear to have left northern India between A.D. 1000 and 1025 during a period of frequent invasions of the Sind and Punjab regions by Islamic forces. Although the ethnic and caste origins of the Roma may have been mixed, prolonged separation from the Punjab weakened their identification with the subcontinent and eventually resulted in a culturally distinct population. Linguistic evidence supports this theory, but a more detailed historical foundation is still lacking. ${ }^{57}$

No reliable sources document the arrival of the Gypsies in the United States or their departure from other countries. ${ }^{58}$ An initial handful may have come with Columbus, and later England deported others. ${ }^{59}$ A significant number of Gypsies arrived in the United States with the immigration waves of the nineteenth and early twentieth centuries. In the United States, the Gypsies were not identified as such for quite some time, for several reasons. First, the United States, with its vast size and mobile population, offered a favorable environment for a population that often does not adhere to a sedentary life. Second, Gypsies commonly do not identify themselves as Gypsies, but merely

54. SWAY, supra note 52 , at 39.

55. Id. at 44; Toby F. Sonneman, Buried in the Holocaust, N.Y. TIMES, May 2, 1992, at A17. For a discussion of the systematic lack of recognition given the Romani holocaust, see generally Sybil Milton, The Context of the Holocaust, 13 GERMAN STUD. REV. 269 (1990). For further details, see supra note 41.

56. CLÉBERT, supra note 44, at 201-02. This does not apply to the Vlax who were enslaved in Rumania for 500 years and thereby compelled to stay in a designated location. See supra note 38 and accompanying text.

57. Hancock, Diaspora I, supra note 38, at 615; Ian Hancock, On the Migration and Affiliation of the Dömba: Iranian Words in Rom, Lom and Dom Gypsy (Occasional Papers, Int'1 Romani Union, Series F, No. 8, 1992); see also DONALD KENRICK \& GRATTAN PUXON, THE DESTINY OF EUROPE's GyPSIES 14-15 (1972). For theories on the origins of Gypsies, see BLOCK, supra note 44, at 32-47; CLEBERT, supra note 44, at 15-23, 26-42; FRASER, supra note 28, at 25-29, 33-40; SWAY, supra note 52, at 31-33; YooRs, GYPSIES, supra note 42, at 9-10; John Sampson, On the Origin and Early Migrations of the Gypsies, $2 \mathrm{~J}$. GYPSY LORE SOC'Y 156, 159 (1923).

58. See JOHN B. MCLAUGHLIN, GyPSY LIFESTYLES 3 (1980).

59. Reportedly, Gypsies entered the Americas with Columbus on his third voyage in 1498. England began deporting Romanichal Gypsies in 1544. Large numbers of Gypsies were sent from England to Virginia and Georgia in 1695. Queen Christina of Sweden had Gypsies deported to her colony in Delaware in 1648. Gypsies from Germany escaped "Gypsy hunts" that had been legalized after the Thirty Years War by coming to America. Ian F. Hancock, The Romani Diaspora Part 2, 1989 THE WORLD \& I 644 [hereinafter Hancock, Diaspora II]. 
indicate their last host home as their nationality. ${ }^{60}$ Finally, the presence of other non-white population groups helped the Roma to blend in unnoticed. ${ }^{61}$

\section{B. Functions of Concepts of Impurity (Marime)}

The Gypsies' determination not to assimilate into the dominant society has been crucial to their survival as a separate population. This drive stems in part from the Roma's belief that non-Gypsies are in a state of defilement because of their ignorance about rules on purity and impurity. Gypsy society relies heavily on distinctions between behavior that is pure (vujo) and polluted (marime). ${ }^{62}$ The marime concept has powerful significance for Gypsies. Marime has a dual meaning: it refers both to a state of pollution as well as to the sentence of expulsion imposed for violation of purity rules or any behavior disruptive to the Gypsy community. Pollution and rejection are thus closely associated with one another ${ }^{63}$ The marime rules minimize and regulate association between Gypsy and non-Gypsy. Although the notion of marime supports the Roma's desire for autonomy, Gypsy pollution taboos evolved in part to prevent dissension and disease among people living in deprived and unstable conditions. ${ }^{64}$

60. Vogel, supra note 29, at 35 ("Rom from Germany are listed as Germans."); see also MCLAUGHLIN, supra note 58, at 3. According to Hancock, the United States adopted immigration policies in the 1880's restricting entrance of Gypsies. Hancock, Diaspora II, supra note 59, at 646-47; see also Ian F. Hancock, Gypsies, in HARVARD ENCYCLOPEDIA OF AMERICAN ETHNIC GROUPS 440, 441 (1980) (hereinafter Hancock, Gypsies]. On the history of American immigration law, especially the aggressive xenophobia advocated in the nineteenth century by the political movements of Native Americanism and the Know-Nothings, see FRANK G. FRANKLIN, THE LEgISLATIVE HISTORY OF NATURALIZATION IN THE UNITED STATES 184-300 (1906).

61. Hancock, Diaspora II, supra note 59, at 647 .

62. SWAY, supra note 52, at 46-59; see also HANCOCK, PARIAH SYNDROME, supra note 1, at 115-16; JUDITH OKELY, THE TRAVELLER-GYPSIES 77-78 (1983) [hereinafter OKELY, TRAVELLER]; YOORS, GYPSIES, supra note 42, at 150; Carol J. Miller, American Rom and the Ideology of Defilement, in GYPSIES, TINKERS AND OTHER TRAVELlERS 41, 45-46 (Farnham Rehfisch ed., 1975) [hereinafter Miller, Defilement] (noting that gajikane living habits confuse pure and impure and invite spreading of contagious disease, especially venereal disease); Judith Okely, Gypsy Women: Models in Conflict, in PERCEIVING WOMEN 55, 59-60 (Shirley Ardener ed., 1975) [hereinafter Okely, Gypsy Women]; cf. JACOB NEUSNER, THE IDEA OF PURITY IN ANCIENT JUDAISM 108 (1973) (discussing purity and impurity as metaphors for moral and religious behavior relating to sex and unethical conduct).

63. SWAY, supra note 52, at 53; FRASER, supra note 28, at 245-47; Carol J. Miller, Mačwaya Gypsy Marimé 5 (1968) (unpublished M.A. thesis, University of Washington (Seattle)) [hereinafter Miller, Thesis]; Miller, Defilement, supra note 62 , at 40 . Miller's pathbreaking field research dealt only with Mačwaya families that belong to the Rom-Vlax group. According to Hancock marime is a Vlax word, unknown to other Romani populations. Some populations have no word for ritual pollution; other groups use a variation of the Indian-derived word makhardo, meaning smeared. Hancock, Review, supra note 35, at 74-75. Not all Gypsy groups adhere to the precise beliefs and practices discussed in this Article, although most Gypsies employ concepts of "pollution" in one form or another.

The notion of pollution exists in most cultures, but it usually does not have the same crucial religious and legal significance as in the case of the Gypsies. Lawrence S. Kubie, The Fantasy of Dirt, 6 PSYCHOANALYTIC Q. 388 (1937) (describing dirtiness as cultural construct); see also Martha G. Duncan, In Slime and Darkness: The Metaphor of Filth in Criminal Justice, 68 TUL. L. REv. (forthcoming March 1994) (on file with authors).

64. MCLAUGHLIN, supra note 58, at 19. But see OKELY, TRAVELLER, supra note 62 , at $78-83$ 
According to romaniya ${ }^{65}$ or Gypsy law, the human body is both pure and impure. The waist is the equator, or dividing line. The lower body is marime because the genital areas and the feet and legs may cause pollution and defilement. ${ }^{66}$ The upper body is fundamentally pure and clean. Any unguarded contact between the lower and upper bodies is marime. ${ }^{67}$ Rituals of purification preserve the power attributed to the upper half of the body and the health of the Gypsy concerned. ${ }^{68}$ Only the hands may transgress the boundary line between the upper and lower parts of the body. ${ }^{69}$

Notions of purity and impurity follow the life cycle. Gypsies consider children marime for six weeks after birth because the birth canal is a polluting site. ${ }^{70}$ After this six-week period, children enjoy a privileged status in society until puberty, when they become subject to marime taboos. ${ }^{71}$ Following the onset of puberty, women remain in a latent stage of impurity until they reach menopause. ${ }^{72}$ In old age, Gypsies believe that one regains some of the innocence of childhood. As one scholar has noted, Gypsies consider elders "close to the gods and the ancestors."" Postmenopausal women do not have the power to pollute by tossing their skirts (as they can before they reach menopause), because they no longer menstruate or bear children. ${ }^{74}$

(stressing concern with inner purity).

65. SUTHERLAND, supra note 29, at 101-02, 263-64, 319 (defining romaniya in Glossary as "the laws and traditions of the Rom"). Romaniya in essence means that which is considered right, true, correct, and acceptable regarding all aspects of living. Hancock, Gypsies, supra note 60, at 443. It covers relationships between Gypsies and with non-Gypsies, including matters of health, food, morality, as well as procedures and rituals. Id. The antithesis of romaniya is marimos, meaning defilement, pollution, or banishment. If something is marime, it is in violation of Gypsy law. Id.

66. Hancock, Gypsies, supra note 60, at 443; Miller, Defilement, supra note 62, at 41-42.

67. SUTHERLAND, supra note 29, at 258, 264; SWAY, supra note 52, at 53; Miller, Defilement, supra note 62 , at 42 .

68. See SUTHERLAND, supra note 29 , at 255-87; Miller, Defilement, supra note 62 , at $42-43$.

69. Miller, Defilement, supra, note 62, at 43. Washing rituals must be performed assiduously after contact with the lower body, especially before food preparation or religious rituals. Id.; see also Miller, Thesis, supra note 63 , at 9-14.

70. SUTHERLAND, supra note 29, at 262; see also Miller, Defilement, supra note 62, at 42-44 ("three days ... to several weeks").

71. SUTHERLAND, supra note 29, at 262.

72. See Miller, Defilement, supra note 62, at 44; see also ElwOOd B. TRIGG, GYPSIES, DEMONS AND DIVINITIES 55 (1973); Aparna Rao, Some Mānuš Conceptions and Attitudes, in GYPSIES, TINKERS AND OTHER TRAVELLERS, supra note 62 , at $139,154-55$. The power of the female's lower body to pollute accounts for the segregation of males and females following puberty. See Rao, supra, at 155; Carol Silverman, Negotiating "Gypsiness": Strategy in Context, 101 J. AM. FOLKLORE 261, 264 (1988) [hereinafter Silverman, Gypsiness]. An exception to sexual segregation occurs while Gypsies watch television. Rao, supra, at 155.

73. Miller, Defilement, supra note 62, at 44 . Miller notes that elders are believed no longer to have an interest in sex. Id. at $44 \mathrm{n}$.10. The conception of age among Gypsies appears to be different from that of non-Gypsies. The advent of old age is signalled by the arrival of the second or third grandehild. See SUTHERLAND, supra note 29, at 263. Many Roma do not know their exact age, so they judge by life cycles (puberty, adulthood and marriage, old age) and visible factors, such as the presence or absence of wrinkles and gray hair. MCLAUGHLIN, supra note 58, at 12; see also SUTHERLAND, supra note 29, at 150-51.

74. Miller, Defilement, supra note 62, at 44 (noting that older women lose power to contaminate by "tossing the skirt"); id. at 51-52 (discussing skirt-tossing as symbolic power to pollute); see also infra note 79 and accompanying text. 
Pollution taboos vary from group to group and often among smaller Romani units. ${ }^{75}$ Nevertheless, Gypsies define themselves in part by their adherence to these cleanliness rituals. ${ }^{76}$ There may be class distinctions among some Roma, based on how strictly individuals or families maintain distinctions between purity and impurity. ${ }^{77}$ All these taboos involve rules that are aspirational. The actual behavior of the Gypsy people is likely to fall short of the communal expectations expressed in the taboos.

According to Elwood Trigg, the marime rules fall into four overlapping categories: (1) taboos directly or indirectly related to the fear of being contaminated by women; (2) sexual taboos; (3) things considered to be dirty or unhygienic; and (4) disdain of socially disruptive behavior. ${ }^{78}$ Adherence to these ritual purity laws is central in setting Gypsies apart from their host cultures.

\section{Contamination by Women ${ }^{79}$}

Women may contaminate men in a number of ways. ${ }^{80}$ Because of menstruation and childbirth, the Gypsies consider the female genitalia impure.

75. See Hancock, Gypsies, supra note 60 , at 443.

76. See OKELY, TRAVELLER, supra note 62 , at 83 . The marime taboos are not completely known or understood by non-Gypsies, who adhere to different and often incompatible notions of cleanliness.

77. SUTHERLAND, supra note 29, at 260; see also Hancock, Gypsies, supra note 60, at 442; MATT T. SAlo \& SheIla M. SAlo, THE KALDERAS IN EASTERN CANADA 115-16 (Canadian Centre for Folk Culture Studies Paper No. 21, 1977). According to LIÉGEOIS, supra note 52, at 76, the marime code enables Gypsy subgroups to distinguish among themselves, and also helps maintain their separation from non-Gypsies. Gypsies use peer pressure to point out behavior that amounts to impurity. They then take action to maintain separation from the behavior to avoid becoming polluted.

78. TRIGG, supra note 72, at 55. Trigg's work focused largely on European Gypsy populations. He uses the term mokadi, as distinguished from marime, in his book. It is probably a derivation of the word makhardo (smeared) of Indian origin. The term marime is derived from Greek and used only by the Vlax. Hancock, Review, supra note 35, at 74-75.

79. It should be noted that many of the elements of Gypsy law described in this Article have come to light only recently, significantly through the efforts of female scholars. The guardians of romaniya are primarily Gypsy women who orally transmit knowledge to their children. Gajikane males could not have obtained this confidential information, because Gypsy women would never reveal many important aspects of Gypsy law, including those which relate to sexual taboos and other highly intimate matters, to a nonGypsy man. SUTHERLAND, supra note 29 , at xiii (crediting female scholars with discovery of the Gypsy "moral code"). Women scholars have also noted the problems of scientific ethics connected with gathering intimate and confidential information. RENA C. GROPPER, GYPSIES IN THE CITY: CULTURE PATTERNS AND SURVIVAL at ix (1975) (noting promises made to Gypsy informants and invasion of privacy); SUTHERLAND, supra note 29, at xii (noting danger of use by police). These same concerns apply to this Article, which disseminates confidential information to a wider public.

Problems similar to those posed by Gypsy law find parallels in other areas of religious law. Female legal scholars have been concerned with reexamining ancient notions of purity and pollution as contained in Jewish and Christian tradition from a feminist perspective. See, e.g., Mary E. Becker, The Politics of Women's Wrongs and the Bill of "Rights": A Bicentennial Perspective, 59 U. CHI. L. REv. 453, 466-67 (1992); Jeanne L. Schroeder, Feminism Historicized: Medieval Misogynist Stereotypes in Contemporary Feminist Jurisprudence, 75 IOWA L. REV. 1135, 1190-95 (1990).

80. See TRIGG, supra note 72 , at 55; Miller, Defilement, supra note 62 , at 42 . The gaji (a non-Gypsy female) normally cannot defile a Rom, and as such is perceived as being outside the scope of the Romani legal system. SALO \& SALO, supra note 77, at 125. 
A severe state of marime befalls any man if a woman lifts her skirt and exposes her genitals to him ("skirt-tossing"). ${ }^{81}$ A woman must never walk by a seated man because her genitals would be at the same height as his face. ${ }^{82}$ A man may not walk under a clothesline where women's clothes are hanging. ${ }^{83}$ Women cover their legs when they sit down and, in mixed company, single women keep their legs together when seated. These stringent rules may explain the traditionally long and wide skirts worn by Gypsy women. ${ }^{84}$ Especially in the United States, clothing has changed among Gypsy women, but skirts typically are still long. Slacks have also become acceptable apparel for women. ${ }^{85}$

Historically, marime taboos were quite strict. For example, if a woman stepped into a stream, no one could drink from it for several hours because the water had been exposed to her genitals. ${ }^{86}$ The same taboo extended to food and dishes, all of which were thrown out if a woman stepped over them. ${ }^{87}$ Even today, some Roma will not rent a lower floor apartment for fear that a woman living upstairs will at some point pollute them by walking overhead. ${ }^{88}$

81. Miller, Defilement, supra note 62 , at 51-52. According to Miller, a woman may toss her shoe at a man's face with the same effect. Id. at $51 \mathrm{n} .20$. Because of the severe consequences for the man, in all likelihood neither of these things ever happen. If they did occur, the defiled male Rom would be cast out of the society permanently. Id. at 52. In most cases, after a period of time the woman would simply deny that it ever happened or say that it was a mistake if it is doubtful that the defilement could be proven. To attempt to deny a man forgiveness under such uncertain circumstances would eventually deadlock a Gypsy judicial proceeding. Miller, Thesis, supra note 63, at 22-23.

A Gypsy male will often take his wife with him when meeting an unknown Gypsy. This assures him that in the event of a squabble he is armed. Miller, Defilement, supra note 62, at 51-52 n.20; see also YOORS, GYPSIES, supra note 42, at 151 . Interestingly, tossing the skirt has been successful in combating the gaje. In one case, police officers attempting to arrest Gypsy males were distracted when "'one of the women lifted her dress over her head' .... 'While the cops stared at her, her companions had time to fiee."' Stanley Penn, Gypsy Gangs Range Across the Country, Stealing Rugs, Gems, WaLl ST. J., Dec. 15, 1988 , at Al, Al0 (quoting Chicago police detective Donald Kuchar).

82. MCLAUGHLin, supra note 58, at 20; SALO \& SALO, supra note 77, at 122; SUTHERLAND, supra note 29, at 151; TRIGG, supra note 72, at 58; see Thomas W. Thompson, The Uncleanness of Women Among English Gypsies, 1 J. GYPSY LORE SOC'Y 15, 23 (1922). In an interview with a Mačvaya couple, one investigator was told that many young women do not observe this rule. Marie W. Clark, Vanishing Vagabonds: The American Gypsies, TEX. Q., Summer 1967, 204, 205-06.

83. MCLAUGHLIN, supra note 58 , at 20.

84. Id,; SWAY supra note 52, at 54; TRIGG, supra note 72, at 58; Okely, Gypsy Women, supra note 62, at 63; Thompson, supra note 82 , at 22.

85. See MCLAUGHLIN, supra note 58, at 20 (observing that Gypsy women sometimes wear blue jeans or slacks); OKELY, TRAVELLER, supra note 62, at 207; SUTHERLAND, supra note 29, at 27 (noting that Gypsies sometime wear "American clothes" in public places); Okely, Gypsy Women, supra note 62, at 63. On the question of whether the women's movement has had any effect on Gypsy households, Hancock notes that when Romani women speak of feminism they usually are talking about non-Gypsy women, because some changes due to feminism are seen as contradicting romaniya (Gypsy law). Letter from Ian Hancock, Professor of Linguistics, University of Texas, to Maureen A. Bell (July 8, 1989) (on file with authors).

86. MCLAUGHLIN, supra note 58 , at 20.

87. Rao, supra note 72, at 151; see GROPPER, supra note 79, at 92-93; MCLAUGHLIN, supra note 58, at 20; SWAY, supra note 52, at 54; TRIGG, supra note 72, at 56; YOORS, GYPSIES, supra note 42, at 150; Okely, Gypsy Women, supra note 62, at 64; Thompson, supra note 82, at 21.

88. SWAY, supra note 52, at 55; Hancock, Gypsies, supra note 60 , at 442 ; David W. Pickett, The Gypsies of Mexico, $45 \mathrm{~J}$. GYPSY LORE SOC'Y 6, 12 (1966). 
Similarly, a woman may get out of the car if her husband has to look under it because of mechanical trouble.

When a Gypsy woman goes to the toilet, special precautions must be taken to prevent any man from entering. Even a married couple will not share the bathroom at the same time. ${ }^{89} \mathrm{~A}$ man can become marime by using a toilet seat that a woman has sat on. To avoid this problem, Gypsies prefer to rent or buy residences that have two bathrooms. ${ }^{90}$ Among some groups, a woman cannot comb her hair or let it down in the presence of a man. ${ }^{91} \mathrm{~A}$ wife must undress with her back to her husband and get into bed before him. She must also rise in the morning before he does. ${ }^{92}$

During her menstrual cycle, a woman is marime and must avoid contact with others. Among some groups, a menstruating woman must eat alone and cannot prepare food that will be eaten by a man. ${ }^{93}$ In addition, she must not sleep with her husband, or he will become polluted. ${ }^{94}$ With the onset of menstruation at puberty, a girl's clothing cannot be washed with men's, boys', or premenstrual girls' clothing. Some researchers have indicated that much of the Gypsies' fixation with menstruation originates in India. ${ }^{95}$

89. MCLAUGHLIN, supra note 58, at 20. Many ritual behaviors focus around the bathroom in Macvaya households. Miller, Thesis, supra note 63, at 14. The strict prohibitions may even survive mixed marriages. See, e.g., Letter from Patti J. Jeatran to Walter O. Weyrauch (Nov. 21, 1990) (on file with authors) [hereinafter Jeatran Letter].

90. SWAY, supra note 52, at 55; see also Jeatran Letter, supra note 89. Romaniya makes no distinction between custom and law. See supra note 65. Furthermore, many Gypsy customs have direct legal consequences. See, e.g., LEE, AUTOBIOGRAPHY, supra note 29, at 37 ("Plumbing is a trade forbidden to Gypsies by their own law. A Gypsy man would be defiled by handling toilet fixtures and would run the grave risk of being socially ostracized.").

Germans often complain that Gypsy refugees urinate and defecate outdoors. See, e.g., Fisher, Germany's Gypsies, supra note 41, at F1 (quoting aide of German Chancellor Helmut Kohl). Gypsy asylum seekers may prefer the outdoors to the polluted facilities provided, which they cannot use without becoming marime. The German and Romani notions of legal behavior directly conflict with one another.

91. MCLAUGHLIN, supra note 58, at 21; TRIGG, supra note 72, at 58; see Thompson, supra note 82, at 23-24.

92. LEE, AUTOBIOGRAPHY, supra note 29, at 45-47 (describing bed rituals). Gypsies traditionally sleep on the floor. Hancock, Notes, supra note 31, at 4 n.43; see also YOORS, GYPSIES, supra note 42, at 17-19. 37 (observing that Gypsies traditionally sleep in open air when climate permits).

93. MCLAUGHLIN, supra note 58, at 20; TRIGG, supra note 72, at 61; Okely, Gypsy Women, supra note 62 , at 65 ; Thompson, supra note 82 , at 38-39. Some Gypsy branches prohibit menstruating women from handling "red" meat or any meat. Id. at $27,37$.

94. Katharine Esty, The GyPSIES: Wanderers in TIME 73-74 (1969); MCLAughlin, supra note 58 , at 20 . In former times even mentioning menstruation in mixed company would place men in danger of being polluted. Okely, Gypsy Women, supra note 62 , at 65 ; Thompson, supra note 82 , at 38 . "Sexual intercourse during the proper time of the month (12th day of [female] cycle to onset of menstruation) is not a polluting act. Sex during a woman's period is very marime." Letter from Marlene Sway to Maureen A. Bell (June 30, 1989) (on file with authors). For an interesting parallel in Mosaic law, see Leviticus 15:24 (man impure for seven days if he lies with a woman during her period). Bleeding in consummation of marriage is a matter of great pride as evidence of virginity. SUTHERLAND, supra note 29, at 226-27.

95. GROPPER, supra note 79, at 92-93 (separate laundering); MCLAUGHLIN, supra note 58, at 20; Okely, Gypsy Women, supra note 62, at 65 ; Thompson, supra note 82 , at 28 . The distinction between melyardo (soiled) and marime (polluted or unclean) is applicable to garments worn and separated for washing. See infra note 113. For example, clothing worn above the waist can be vujo if it is clean and melyardo if it is soiled, but clothing worn below the waist is marime. Children's clothing can at worst be melyardo. SUTHERLAND, supra note 29 , at 268 . Regarding the taboos surrounding menstruation in India, 
Pregnancy also signals danger of pollution for others. A pregnant woman may not prepare food for other Gypsies. She is expected to eat by herself and her food must be cooked in her own pots and pans. ${ }^{96}$ She cannot share a bed with her husband. ${ }^{97}$ Even after birth, there is still a period of time, up to six weeks, during which a woman is unclean. In former times, a pregnant woman's clothing, bedding, utensils, and even her tent were burned. Today, Gypsies view childbirth in hospitals as a convenience because the gaje dispose of the polluted items. ${ }^{98}$ In public, couples strictly observe marime taboos, but privately husbands and wives may relax the standards somewhat. ${ }^{99}$

\section{Sexual Taboos}

Sexual taboos have great importance in Gypsy law. The potential for defilement is greatly heightened at marriage because Gypsies perceive it as the end of a woman's innocence. ${ }^{100}$ Traditionally, marriage for Gypsies has

see MCLAUghlin, supra note 58, at 20; GABRIELLE TYRNER-STASTNY, THE GYPSY IN NORTHWEST AMERICA 14 (1977). On the other hand, menstruation and the capacity of women to pollute also has been of intense concern in Jewish and Christian religious law. Becker, supra note 79, 466 (discussing menstruation and childbirth as polluting). See generally BLOOD MAGIC: THE ANTHROPOLOGY OF MENSTRUATION (Thomas Buckley \& Alma Gottlieb eds., 1988).

96. MCLAUGHLIN, supra note 58, at 21; OKELY, TRAVELLER, supra note 62, at 210-11; TRIGG, supra note 72, at 59; Thompson, supra note 82 , at 26,32 .

97. McLAughlin, supra note 58, at 21. Among the Mačvaya and Kalderasha, sexual intercourse between husband and wife is not taboo during a pregnancy as long as there is no vaginal spotting and bleeding. Letter from Marlene Sway, supra note 94.

98. SALO \& SALO, supra note 77, at 131; Okely, Gypsy Women, supra note 62, at 66-67. According to McLaughlin, at the end of this untouchable period, a woman who has given birth "must undergo an elaborate ceremony to cleanse herself. She must destroy everything that she wore during her period of defilement, and she must wait another 40 days before resuming sexual relations with her husband." MCLAUGHLIN, supra note 58, at 21 ; see also Becker, supra note 79, at 466 (discussing purification by ritual bath after menstruation and child birth in Jewish tradition).

99. SUTHERLAND, supra note 29 , at 266 . Generally autonomous systems can exist within other autonomous systems. Thus, the Gypsy family, in relaxing otherwise binding restrictions of romaniya within its jurisdiction, may enjoy a certain degree of autonomy within the larger autonomous legal system of the Gypsies.

100. Miller, Defilement, supra note 62 , at $43-44$. 
occurred early, after age nine but usually before age fourteen. ${ }^{101}$ Gajikano influence may have undermined this tradition. ${ }^{102}$

Sexual mores are rigorously enforced and a wife's complaint of "shameful practices" is ground for annulment as well as a sentence of marime and banishment of the husband. Gypsy law considers oral sex, sodomy, and homosexuality crimes against nature and prohibits them, although these acts may occur in secrecy. ${ }^{103}$ Moreover, even "appropriate" sexual activity between husband and wife may be "tinged with shame."104 Merely making implicit references to genitals, defecation, or sexual intercourse brings shame, especially when both sexes are present. In addition, Gypsies consider yawning or looking sleepy shameful, because they suggest that one is thinking about going to bed. ${ }^{105}$

In spite of myths of Gypsy immorality, most Roma follow strict rules of sexual behavior. Prostitution and infidelity are unusual. ${ }^{106}$ Marime rules are particularly harsh on women. For example, if a Gypsy male marries a gaji (non-Gypsy female), his community will eventually accept her, provided that she adopts the Gypsy way of life. But it is a worse violation of the marime code for a Gypsy female to marry a gajo (non-Gypsy male),

101. See generally MCLAUGHLIN, supra note 58, at 14-15; Marna F. Fisher, Gypsies, in MiNORITY Problems 50, 51 (Caroline B. Rose \& Amold M. Rose eds., 1st ed. 1965) [hereinafter Fisher, Gypsy Minorities]. According to Sutherland, a first marriage ideally occurs before the eighteenth birthday. SUTHERLAND, supra note 29, at 223. Marital age among the Kalderasha in Canada has risen to an average age of eighteen, although marriage between fourteen-year-olds is not uncommon. SALO \& SALO, supra note 77, at 144-45. Among the urban Gitanos in Spain, most men wed between seventeen and twenty-two. Women wed between fifteen and seventeen years of age, which is young in comparison with the Spanish non-Gypsy population. Teresa San Román, Kinship, Marriage, Law and Leadership in Two Urban Gypsy Settlements in Spain, in GYPSIES, TINKERS AND OTHER TRAVELLERS supra note 62 at 169,182 . For similar observations among the Gypsy population in Britain, see OKELY, TRAVELLER, supra note 62, at 153.

Premarital sex reduces the amount of the bride price drastically. See SwAY, supra note 52, at 64 . Yet abortion is exceedingly rare among Gypsies. CLÉBERT, supra note 44, at 162 . According to Hancock, Gypsy boys typically date non-Gypsy girls (raklia). It is through these encounters that they acquire sexual expertise. Nonetheless, adult Gypsies discourage romantic involvement with raklia. Hancock, Review, supra note 35 , at $77-78$.

102. TRIGG, supra note 72 , at 65 .

103. CLÉBERT, supra note 44, at 175; TRIGG, supra note 72, at 64-65; Miller, Defilement, supra note 62 , at 42 . No distinction is made between married or single Gypsies in regard to these prohibitions.

104. Silverman, Gypsiness, supra note 72, at 263. Silverman does not explain this observation. Okely indicates that loss of virginity even within marriage is viewed as a loss of purity, an unclean act. OKELY, TRAVELLER, supra note 62, at 209. The Romani word for "deflowered" is porradi, which means "spread apart," "split open," or "broken." Hancock, Notes, supra note 31, at 4 n.49. Parallels exist in Christianity. See 1 Corinthians 7:7-9 (stating Paul's admonition that staying unmarried is preferable to marriage, although marriage is permissible for those who cannot contain themselves); see also Schroeder, supra note 79 , at 1190-95 (discussing views of medieval theologians that female sexuality is ritually polluting).

105. Miller, Defilement, supra note 62, at 42 n.3. Roma avoid the word pato for bed and use the euphemism than (place) instead. Hancock, Notes, supra note 31, at 4 n.48.

106. CLÉBERT, supra note 44, at 175; TRIGG, supra note 72, at 62-64. But it is not unusual, and sometimes even encouraged, for a Gypsy male to have clandestine sexual relations with a gajikani female. He must act with utmost discretion, because if he were found out he and his family would be marime. See Miller, Thesis, supra note 63, at 32-34; SuTHERLAND, supra note 29, at 262-63; see also San Roman, supra note 101 , at 193. 
because Gypsy women are the guarantors for the survival of the population. ${ }^{107}$ Gypsies expect females to be virgins when they marry and to remain faithful to their husbands until death. Infidelity in marriage historically has had serious consequences for the wife, including mutilation or a sentence of marime. ${ }^{108}$

\section{Hygienic Matters}

Complex rules also govern tangible items considered dirty or unhygienic. ${ }^{109}$ In Romani society, food preparation is replete with ritual. A woman must serve a man from behind and guard against reaching across or in front of him. Gypsies use the dining table exclusively for eating and keep it immaculately clean. In the past, women wore full white aprons when preparing meals or mending men's clothing in order to protect the food or clothing from the "dirt" of their dresses. ${ }^{10}$ Gypsies guard their dishes and utensils closely and generally do not share them with their gajikane guests. Visitors have to

107. Miller suggests that the temporary period of marime for the gajikani wife lasts for approximately three to four months. During this time the gaji is taught proper washing and avoidance behavior. Miller, Thesis, supra note 63, at 15 . Intermarriage remains rare. Hancock, Gypsies, supra note 60, at 442. According to a Romani source, intermarriage may have undesirable results because the mixed couple loses the full support of the Roma without gaining the respect of gajikano society. LEE, AUTOBIOGRAPHY, supra note 29 , at 104, 117. Concern about intermarriage has also been raised in Jewish communities. See $R$. Gustav Niebuhr, Keeping the Faith: Marriage and Family No Longer Are Ties That Bind to Judaism, WALL ST. J., Aug. 8, 1991, at A1. According to Jewish law, which is matrilineal, the religion of the mother determines whether the child is born Jewish. Id. at A6.

With regard to marriages of Gypsy women to gajikane men, see SUTHERLAND, supra note 29, at 247-53; Miller, Defilement, supra note 62, at 45 . Such a marriage is likely to be perceived as a rejection of romaniya (Gypsy law). The character and quality of a Gypsy woman is largely judged by whether she is perceived to be respectable, which is determined by whether she follows Gypsy laws and customs. LEE, AUTOBIOGRAPHY, supra note 29 , at 57.

108. ClÉBERT, supra note 44, at 175-76; TRIGG, supra note 72, at 62-64. Quintana and Floyd assert that Gypsy females in Spain strongly support the double standard as well as the punishments. The Gitana maintain that their fidelity is further proof of their superiority. BERTHA B. QUINTANA \& LOIS G. FLOYD, ¡QUÉ GITANO! GyPSiEs OF SOUTHERN SPAIN 36 (1972).

109. Trigg groups various Romani taboos under the heading mokadi. TRIGG, supra note 72, at 54-55. The Vlax Roma distinguish between things that are melyade (visibly dirty) and things that are marime (ritually polluted). These concepts are perceived differently by the Vlax Roma and the non-Gypsies. The gaje focus on visible dirt. The Roma, however, are concerned with inward cleanliness. Each perceives the other as dirty or polluted. GROPPER, supra note 79, at 91. An untidy or unkept home would not be marime, assuming adherence to marime regulations regarding washing and preparation of food. Instead, the home would be considered melyade. Untidiness can generate much gossip, even heated debate within a kumpania (a group of Roma living or travelling together). A house, however, that has been occupied only by Roma, even if it is melyade, is still considered "cleaner" than a home formerly occupied by non-Gypsies or by a banished Roma family. The Gypsies consider the latter two marime. SUTHERLAND, supra note 29, at 270; sce also supra note 62.

The Vlax also have a concept of pokelime for something that is already defiled. Gajikane movies, literature, mass communication, and advertisements are pokelime, because they were polluted at their inception. Hancock, Review, supra note 35, at 74-75 (noting also the differences in terminology among various Romani populations).

110. MCLAUGHLIN, supra note 58, at 21 (discussing eating rituals). According to Okely, small aprons are still worn today and symbolize "a true Gypsy." OKELY, TRAVELLER, supra note 62, at 208; see also TRIGG, supra note 72, at 56-57; Thompson, supra note 82, at 19, 24. 
provide their own. If necessary, their hosts provide them with a set which traditionally must be destroyed afterwards or saved for other non-Gypsy visitors. Today, Gypsies use paper or plastic plates and tableware for this purpose. Silverware may regain purity after being soaked in bleach. Food in which a hair has been found must be discarded. Blowing one's nose or sneezing would pollute the food and make the offender marime, as would neglecting to wash one's hands before eating. A man who touches a woman's skirt should not handle food without washing his hands first. ${ }^{111}$ Even a shadow can pollute food. ${ }^{112}$

A kitchen sink cannot be used for washing hands or clothes, only for cleaning dishes and silverware. A Rom who accidentally washes his hands in a basin for washing dishes is marime. Dishes that are mistakenly washed in a "polluted" place, regardless of their apparent cleanliness, must be destroyed or soaked in bleach. Gypsies divide their living quarters into marime and vujo areas. The front of the house could be marime unless protective measures are taken, since this is where the gaje may enter. Gypsies often reserve one chair for gajikane visitors. A Rom must never sit in this chair, for if he does, he will be deemed marime. Today, other furniture is protected from pollution with plastic covers. Gypsies never permit gaje in the back of the house. ${ }^{113}$

The division between pure and impure extends to bodily by-products. Gypsies consider tears, spit, and even vomit clean because they emanate from the top half of the body, whereas emissions from the lower half of the body are polluting. Gypsies will take extreme measures to conceal the fact that they need to urinate. ${ }^{114}$

Marime taboos extend to animals as well, from the edibility of certain types of meat to pet ownership. For example, dogs and cats, as opposed to horses, are considered polluted because of their unclean living habits. Gypsies

111. MCLAUGHLiN, supra note 58, at 21-22; SALO \& SALO, supra note 77, at 120-21; cf. RAV ZVI Cohen, Tevilath Kelim: A COMPREhensive Guide 17, 37, 115 (1988) (discussing Judaic laws that require ritual washing of utensils acquired through purchase or gift from non-Jewish sources); MOSHE MORGAN, A GUIDE TO THE LAWS OF KASHRUS 107 (discussing whether it is permissible to use refrigerator which has been used by non-Jew). The reader is cautioned that rules in communities of different ethnic backgrounds, even if outwardly comparable, may be based on substantially different rationales.

112. The shadow of the gaje is particularly polluting. Judith Okely, Why Gypsies Hate Cats but Love Horses, 63 NEW SOC'Y 251, 252 (1983) [hereinafter Okely, Cats].

113. On cleanliness and visitors, see generally MCLAUGHLIN, supra note 58, at 21-22; YOORS, GYPSIES, supra note 42, at 150; Okely, Gypsy Women, supra note 62, at 60; Thompson, supra note 82, at 20. If used and washed properly, items commonly used for food preparation such as tablecloths, dish towels, and dishes can become melyade. They do not become marime unless prohibited contact is made, for example, when a towel falls on the floor. SUTHERLAND, supra note 29, at 266-69. When moving into a house that has been occupied by gaje, Gypsies may board up sinks or replace them with new ones for fear that the original facilities were used for improper purposes, in particular urination. OKELY, TRAVELLER, supra note 62, at 82; SALO \& SALO, supra note 77, at 120.

114. SUTHERLAND, supra note 29, at 265-66; YOORS, GYPSIES, supra note 42 , at 30 . According to Vogel, supra note 29, at 37, even fiushing the toilet can be embarrassing for many Roma. Among the Gitanos in Spain, however, many of these taboos have virtually disappeared. MERRILL MCLANE, PROUD OUTCASTS 48 (1987). 
consider cats particularly unclean because they lick their paws after burying their feces. The critical concern (as with dogs licking themselves) is that the uncleanliness of the external world may defile the purity of the inner self if it is permitted to enter the body through the mouth. Cats are also a sign of impending death. If a cat sets foot in a Gypsy's house, trailer, or automobile, a purification ceremony is required. Dogs are also unclean, but to a lesser extent. Dogs are tolerated outside the house because of their value as watchdogs. ${ }^{115}$

\section{Social Transgressions}

Socially disruptive behavior may result in legal sanctions, including a sentence of marime. In addition to strong taboos against exploiting or stealing from a fellow member of the Gypsy community, Gypsies consider crimes of violence and noncommercial association with gaje as crimes against Romani society as a whole and therefore marime. ${ }^{116}$ A marime label can be removed by the forgiveness of the offended party, the passage of time or by a Gypsy legal proceeding called kris Romani. Readmission to Gypsy society following a sentence of marime is cause for celebration. ${ }^{17}$

In all cases of marime, enforcement depends primarily on a superstitious fear of the consequences of violating the marime rules. The individual who violates a marime prohibition has succumbed to powers of evil and destruction that are so frightening that even his own family shuns him for fear of contamination. Such an individual becomes tainted and can be redeemed only by making the prescribed amends. ${ }^{118}$

115. MCLAUGHLIN, supra note 58, at 22; OKELY, TRAVELLER, supra note 62, at 91-97; TRIGG, supra note 72, at 69; Okely, Cats, supra note 112, at 253 (describing rejection of cats for being polluted). The Biblical rules, Leviticus 11:2-22; Deuteronomy 14:4-21, prohibit eating dogs and cats. For many people, regardless of their religious or ethnic affiliation, these prohibitions have become rules of oral legal tradition.

116. GROPPER, supra note 79, at 90, 106; SUTHERLAND, supra note 29, at 257-58; SWAY, supra note 52, at 78; YoORS, GYPSIES, supra note 42, at 176-79 (describing a Gypsy trial relating to theft); Miller, Defilement, supra note 62, at 46 (discussing noneconomic association with gaje); San Román, supra note 101, at 191-94 (describing substantive criminal law among Gitanos in Spain). Much behavior that is acceptable to and commonplace among non-Gypsies is taboo for the Roma. Consequently, any exchange with gaje entails a risk of pollution. LIÉGEOIs, supra note 52, at 76.

117. MCLAUGHLIN, supra note 58 , at 20 (noting ways in which one can remove oneself from marime state).

118. TRIGG, supra note 72, at 55. Trigg uses the term mokadi instead of marime. The terms vary depending on the particular Romani population involved. The fear of being declared marime is a powerful means of social control. Letter from Marlene Sway, supra note 94 ("Even if a Gypsy is tried on a marime charge and is cleared by the kris, the stigma or cloud of doubt lingers for his or her entire lifetime."). Some observers have suggested similar aspects in our own proceedings that prevent rehabilitation. Goffman notes that "barbarous ceremonies" in our society, such as criminal trials and courts-martial, have the sole purpose of preventing the accused from saving face. Erving Goffman, On Cooling the Mark Out: Some Aspects of Adaptation to Failure, 15 PSYCHIATRY 451, 462 (1952). Disclosure of arrest records, whether the accused was convicted or not, are required on immigration and naturalization applications, applications for law schools, applications for taking the bar examination and for being admitted to the practice of law. For example, see Florida Board of Bar Examiners, Application for Admission to the Florida Bar, form 1, revised Dec. 1992, Question No. 20 a: 


\section{Administration of Justice}

Because of the general lack of territorial boundaries, each Gypsy group can determine its own form of adjudication. Although there are many words for "group" in the Gypsy language, four primary associations can be identified: natsia, meaning nation; kumpania, an alliance of households not necessarily of the same natsia but of the same geographic area bound together for socioeconomic reasons; vitsa, or clan; and familia, which consists of the individual extended family. ${ }^{119}$ Each associational unit is involved in the administration of justice, beginning with the smallest, the familia, which informally settles minor disputes, and extending to the larger units with increasing formality.

\section{Role of Chiefs}

Gypsies have no kings in the traditional meaning of the term. ${ }^{120}$ Every vitsa has a rom baro, literally meaning "Big Man," commonly referred to as the chief. The chief is elected for life, and the position is not inheritable. ${ }^{121}$ If a chief dies or falls into disgrace, another chief is chosen to replace him. The main criteria for chiefdom are intelligence and a sense of fairness. Wealth and large physical stature are not required, although they help. Most chiefs are

List all instances in your entire life (including while you were a juvenile) in which you have been arrested, detained or restrained, given a warning or taken into custody or accused, formally or informally, of the violation of a law, or ordinance, or accused, formally or informally, of committing a delinquent act and attach a detailed explanation of the facts and the subsequent actions taken by the authorities.

A preamble clarifies in greater detail that no expunging or sealing of records, or dismissing, vacating or setting aside any arrest "shall excuse less than full disclosure, irrespective of any advice from any source that such information need not be disclosed." See also Michelson v. United States, 335 U.S. 469, 482 (1948) ("Arrest without more may nevertheless impair or cloud one's reputation."); Menard v. Mitchell, 430 F.2d 486, 491 n.24 (D.C. Cir. 1970) ("Presumably the fact of arrest indicates some possibility that the individual concerned engaged in the criminal activity with which he was charged.").

119. See also SUTHERLAND, supra note 29, at 10-13, 32-34, 181-205; SWAY, supra note 52, at 61; YOORS, GYPSIES, supra note 42, at 134-35; Anne Sutherland, Gypsies: The Hidden Americans, 12 SOCIETY 27, 28 (1975); Lí́GEOIS, supra note 52, at 57-66. Within each kumpania, there are further divisions called wortacha (partners). These groups are formed between members of the same sex who work together. They may include fathers and sons, or mothers and daughters. SUTHERLAND, supra note 29, at 66-68. But see Hancock, Gypsies, supra note 60 , at 442 (noting that Romanichals only divided into clans and families). The Lovara do not use the term vitsa. Hancock, Notes, supra note 31, at 5 n.56.

120. On the absence of law enforcement, see YOORS, GYPSIES, supra note 42, at 174 . On the absence of kings, see SWAY, supra note 52, at 61. According to Yoors, "kings" existed among the European Lovara, but not as portrayed by the media. These kings were actually informal intermediaries between the real chiefs and the local gajikane authorities. YOORS, GYPSIES, supra note 42, at 114-16. GROPPER, supra note 79 , at 70-72, indicates that these false "kings" do not exist in the United States. For an illustration of how the label "king" was attached to a Gypsy spokesman by a reporter, see LEE, AUTOBIOGRAPHY, supra note 29 , at 111-21.

121. CLEBERT, supra note 44, at 126-28. Yet GROPPER, supra note 79, at 71 , notes that one of the sons of a former chief typically becomes the next leader. 
literate. ${ }^{122}$ Elders are considered particularly suited to this role because they have greater knowledge of romaniya and are believed to be less susceptible to the temptations of violating the marime code. The chief chairs the council of elders, generally the patriarchs of the extended families. He is held accountable if he himself violates Gypsy law or ignores the other chiefs. All chiefs have equal authority and decide jointly about when the larger group should migrate. ${ }^{123}$

There is a female counterpart to the chief. Her power is unofficial but substantial. The Vlax call her mami, daki-dei or dadeski-dei. Other Gypsy groups use the term phuri-dae (old mother). She is the guardian of the moral code and helps decide matters involving women and children. In important affairs involving the entire kumpania, she is the spokeswoman for Gypsy women. ${ }^{124}$

The tribal chiefs are not necessarily aware of all the laws; not only are the laws too numerous, but many laws have been lost because they have never been written down. The Gypsies interpret laws according to contemporary custom. Former rationales and interpretations of laws gradually may be revised as the needs of the community evolve. The exclusive reliance on oral transmission has led to a high degree of flexibility. Nevertheless, there is a shared, though not necessarily realistic, feeling that the law is clearly defined. Few ever challenge this notion. This strict adherence to the law in part accounts for the continued cohesion of the Gypsies in spite of their persecution and forced migration. Secrecy surrounds Gypsy law; unauthorized disclosure to the gaje may lead to sanctions. ${ }^{125}$

Each chief handles all day-to-day conflicts within his population. When conflict emerges between Gypsies of different vitsi or kumpaniyi (singular kumpania), a divano may assemble. ${ }^{126} \mathrm{~A}$ divano is an informal proceeding

122. With regard to the Roma, see CLÉBERT, supra note 44, at 126 . Some authors suggest that the rom baro is self-appointed and not selected or elected. See MCLAUGHLIN, supra note 58, at 16; SALO \& SALO, supra note 77, at 55-56. According to SUTHERLAND, supra note 29 , at 116 , a rom baro should ideally be tall and have a large body frame and head. Literacy may be desirable or even necessary because of the rom baro's role as a liaison between the Roma and the gajikane authorities. On literacy see GROPPER, supra note 79 , at 71 ; SWAY, supra note 52 , at 61 .

123. ClÉBERT, supra note 44, at 126-28. See generally GROPPER, supra note 79, at 70-80, 102. According to SUTHERLAND, supra note 29 , at 104 , there is a positive correlation between age and knowledge of romaniya (Gypsy law).

124. CLÉBERT, supra note 44, at 128; SWAY, supra note 52, at 61-62. According to BLOCK, supra note 44 , at $170-71$, the old mother traditionally had some formal powers. For example, although the chief had to be present at weddings, it was the old mother who performed the ceremony. If the chief was unavailable for dispute consultation, it was the old mother who made the final adjudication. So powerful was her presence that even her glance and cry, "I am old, I am old," struck fear in all, because she had the power to inflict curses and bring bad luck. See also Rao, supra note 72, at 143-44.

125. CLÉBERT, supra note 44, at 131-32 (discussing secrecy); GROPPER, supra note 79, at 98 (discussing flexibility of romaniya and oral tradition).

126. LEE, AUTOBIOGRAPHY, supra note 29, at 68; MCLAUGHLIN, supra note 58, at 22-23. According to Pickett, supra note 88, at 6-7, the Gypsies of Mexico successfully used the divano for dispute resolution. But see Jan Yoors, Lowari Law and Jurisdiction, 26 J. GYPSY LORE SOC'Y 1, 2 (1947) [hereinafter Yoors, Lowari Law] (noting that divano may perpetuate quarrels and result in interminable discussions). 
where the chiefs of the various clans try to mediate a dispute. The parties themselves are not required to attend-and they are not technically bound by the chiefs' suggestions. But the contestants sometimes do bow to peer pressure and settle the case. Blatant disregard for the chiefs' recommendations could cost them the respect of the community. ${ }^{127}$

\section{Role of Courts (Kris)}

When the Roma cannot settle a controversy amicably in a divano, a kris may become necessary. ${ }^{128}$ In former times, the kris usually adjudicated three kinds of cases: property losses, matters of honor, and moral or religious issues, including nonobservance of marime taboos. ${ }^{129}$ Brawls, demands by parents for return of their married daughters, defaults in payments of debts, marime violations and personal retribution all required the attention of the kris. ${ }^{130} \mathrm{In}$ the United States today, the kris calendar is largely occupied by divorce cases and economic disputes. ${ }^{131}$

Divorce cases are complex. Even today, most Gypsy marriages (which may not be legal marriages according to gajikano law) are arranged, and the groom's family pays a bride price. If the marriage ends in divorce, a kris may

The Emirate of Kuwait has an institution called diwaniya. In regularly scheduled meetings, headed by the Crown Prince, friends and members of the extended family gather to discuss grievances. John Kifner, After the War: Emir Disparaged at Kuwaiti Forums, N.Y. TIMES, Mar. 27, 1991, at A8. The word divano is of Persian origin and means council of state or court of justice. Lee, Kris, supra note 51, at 20 n.1.

127. MCLAUGHLIN, supra note 58, at 23; see also SUTHERLAND, supra note 29 , at 131 . According to a Gypsy saying, "It's better to part as friends from a divano, than as enemies from a kris." Hancock, Notes, supra note 31 , at 5 n.59.

128. SwaY, supra note 52, at 77. For an excellent description of the kris and the applicable law, see Lee, Kris, supra note 51. Lee cites with approval GROPPER, supra note 79, and SALO \& SALO, supra note 77. See also David J. Nemeth, Gypsy Justice in America, 1 J. GYPSY LORE SOC'Y 3 (1974); David J. Nemeth, Field Notes from 1970: A Kris in River City, in 100 YEARS of GYPSY STUDIES 117 (Matt T. Salo ed., 1990) [hereinafter Nemeth, Field Notes]. The word kris is not of Indian origin. The term derives from the Greek word krisis, meaning judgment. FRASER, supra note 28, at 56; Lee, Kris, supra note 51, at 19. The kris as a judicial institution exists among the Vlax, the most numerous Romani group in the United States. It appears that the conditions of slavery in Rumania, under which the Vlax lived for five centuries, helped to preserve the kris as part of their distinct culture. See Hancock, Diaspora I, supra note 38, at 617. The Vlax kris may be modeled after a council of elders of non-Gypsy villagers in Rumania that also settled disputes. Hancock, Notes, supra note 31, at 5 n.59. The Romanichals (British Gypsies) and the descendants of Balkan Gypsies, who were not enslaved, do not have the kris. Lee, Kris, supra note 51, at 19.

129. Yoors, Lowari Law, supra note 126, at 3. During kris proceedings the litigants agree to a truce. Id. at 11. According to GROPPER, supra note 79, at 82, a judge will not accept a case for a kris unless the litigants take an oath promising to abide by the decision. See also MCLAUGHLIN, supra note 58, at 23.

130. C.-H. Tillhagen, III. Conception of Justice Among the Swedish Gypsies, 38 J. GYPSY LORE SOC'Y 18, 19 (1959) [hereinafter Tillhagen, III]. A detailed list of controversies falling under the jurisdiction of the kris is also contained in Lee, Kris, supra note 51, at 21-22. See also SUTHERLAND, supra note 29, at 292-304 (giving account of two Gypsy trials: (1) kris Romani in New Orleans and (2) divano in Wichita, reported by John Marks, party to proceedings).

131. According to GROPPER, supra note 79, at 85-91, four kinds of cases dominate the kris calendar in the United States: (1) work related, e.g., unfair division of profits; (2) divorce; (3) feuding between extended families and bands; and (4) matters similar to our criminal cases, e.g., murder, rape, theft (marime violations). See also Salo \& Salo, supra note 77, at 59, for parallels to Kalderasha in Canada. 
be called to determine how much, if any, of the bride price should be returned to the groom's family. ${ }^{132}$

Economic cases, on the other hand, cover such issues as who has the right to engage in fortune-telling in a specific territory. Gypsies believe that every Gypsy has the right to work. Accordingly, groups divide territory into economic units. Controversies may result when some Gypsies poach on others' turf, and then a kris is called. A first-time offender may receive a warning by the kris. Repeated violations result in a sentence of marime. ${ }^{133}$

In all cases, it is the aggrieved party who must request the kris, which is then held at a neutral kumpania. If the alleged victim is old, sick, or very young, the victim's nearest male relative brings the case to the kris. If the welfare of the community demands joint action, the entire clan may be a plaintiff. ${ }^{134}$

The elders of the tribes then hold a meeting and select one or more men to act as the krisnitorya (singular krisnitori), or judges. The plaintiff is allowed to choose the judge who will preside over his case, but the defendant has a right to veto that choice. ${ }^{135}$ Among the Roma in the United States it is not unusual for more than one judge to preside. ${ }^{136}$ The senior judge is

132. GROPPER, supra note 79, at 88-89; SWAY, supra note 52, at 73. According to Hancock, Gypsies, supra note 60 , at 442 , arranged marriages are fairly common among both the Romanichals and the Roma (Gypsies of eastern and southern Europe, principally the Mačaya, Kalderasha, Churara, and Lovara). Sometimes the marriage agreement, arranged by the parents, is completed prior to the child's birth.

A Gypsy woman may occasionally use the gajikane courts to get a more favorable divorce settlement. But this is a violation of romaniya (Gypsy law) and may result in a kris. It appears that Gypsy marriages and divorces are de facto recognized by the gajikano legal system. This tolerance may be due to official indifference, or it may be due to American state-law presumptions of what constitutes marriage. See Walter O. Weyrauch, Informal Marriage and Formal Marriage: An Appraisal of Trends in Family Organization, 28 U. CHI. L. REV. 88, 105-08 (1960). Moreover, some states still recognize common-law marriage. The requirements for the presumption of marriage and common-law marriage are identical: cohabitation and the repute of being married. The minimum ages for a valid common-law marriage were, and in some states still are, 12 for the female and 14 for the male. HOMER H. CLARK, THE LAW OF DOMESTIC RELATIONS IN THE UNITED STATES 49-50 (on cohabitation and repute of being married), 89 n.8 (on age limits) (2d ed. student ed. 1988).

133. SWAY, supra note 52 , at $88-89$.

134. MCLAUGHLIN, supra note 58, at 23; SUTHERLAND, supra note 29, at 134; Yoors, Lowari Law, supra note 126, at 3-9 (noting that Romani group may act as plaintiff if victim fails to complain about an act that shames community as whole, e.g., adultery; winner pays for feast following kris). According to SUTHERLAND, supra note 29 , at 132 , the public and not the litigants decide to have a kris, in serious civil matters as well as in criminal matters.

In the United States, calling a kris involves notifying the parties, renting a "courtroom" or hall, and making provisions for food and beverage for all in attendance. The guilty party pays all the costs including travel expenses. GROPPER, supra note 79, at 96; SWAY, supra note 52, at 78 .

135. Tillhagen, III, supra note 130, at 21 (describing selection of judge for Swedish kris). The procedure for the American kris is probably similar because it requires the parties to agree on the judge, usually after protracted haggling. See Lee, Kris, supra note 51, at 26, 29.

136. MCLAUGHLIN, supra note 58, at 23. No firm rule suggests when more than one judge should be selected. YOORS, GYPSIES, supra note 42 , at 174 , states that without a permanent judicial cadre, the selection of judges would depend upon the number of qualified men available. Lee refers to the krisnitorya as an advisory body sitting together with the judge or judges. Since these men appear to be "associate judges" rather than a jury, they may sometimes have been mistakenly counted as judges. Lee, Kris, supra note 51 , at 26 . 
surrounded by the members of the kris council, who act as associate judges. ${ }^{137}$ Generally, five or more men from both sides, usually the elders, form the council. In the United States, the council may have as many as twenty-five members. ${ }^{138}$

The audience of a kris was once largely male. Women and unmarried or childless men were allowed to attend only if they were needed as witnesses. It is now acceptable, if unusual, to have the entire family present for support. ${ }^{139}$ Witnesses may speak freely about the case, for the Gypsies believe there can be no justice without hearing the matter out to its fullest. ${ }^{140}$ Exaggerated claims and ornate stories referring to folktales and mythology are common. ${ }^{141}$ When members of the audience think the witness is not being truthful or responsive, they hiss or make jokes. ${ }^{142}$ In some delicate matters, such as adultery, the public and witnesses can be excluded. ${ }^{143}$ At a kris only Romani may be spoken, and participants discourage lapses into English by shouting and hissing. Furthermore, arguments are often presented in a special oratory that differs grammatically from ordinary Romani and resembles a legal jargon. ${ }^{144}$ When the accused testify on their own behalf they are expected to be truthful. ${ }^{145}$ The kris can further insure their honesty by invoking the magic

137. CLÉBERT, supra note 44 , at 130 .

138. MCLAUGHLIN, supra note 58, at 23. It should be remembered that the kris procedure is based on oral tradition and may vary from case to case and depending on what particular Romani group is involved. YoORS, GYPSIES, supra note 42 , at 174 . These variations may also determine who may participate and on what terms. See supra note 136.

139. GROPPER, supra note 79, at 83 (noting that no Gypsy would be denied admission to kris); Yoors, Lowari Law, supra note 126, at 6 . Among the Swedish Gypsies, women accompanied their husbands to the kris. Tillhagen, III, supra note 130, at 21. The Gitanos in Spain do not tolerate the presence of women. See QUINTANA \& FLOYD, supra note 108, at 73. Their presence at the kris is also not permitted in Canada, except in the capacity of witness. Lee, Kris, supra note 51, at 26.

Jeatran, the daughter of a Lovara Rom and a gajikani woman, has studied American Gypsies and reports that women may attend the kris, although they are not permitted to speak unless they are litigants or witnesses. A Romani informant has told Jeatran that "because we are in America now, so we have to respect the 'Women's Lib."' Patti J. Jeatran, Disputing and Social Control Among American Gypsies 22 (Nov. 14, 1990) (unpublished paper, University of Illinois Department of Criminal Justice, on file with authors) [hereinafter Jeatran, Social Control]. According to Jeatran's informant, women are not allowed to participate in the kris because "if an old one speaks, a young one will start arguing with her and disrupt everything." Id. at 26 . Hancock stresses that he has never been to a kris where women were let into the hall. Hancock, Notes, supra note 31, at 5 n.60.

140. GROPPER, supra note 79, at 81-84.

141. MCLAUGHLIN, supra note 58, at 23-24.

142. SWAY, supra note 52, at 78 (noting hissing and joking as informal sanctions). Tillhagen, III, supra note 130, at 24, reports that Swedish Gypsies did not tolerate such disruptions. The European Lovara also adhered to strict rules of behavior. See Yoors, Lowari Law, supra note 126, at 11.

143. Yoors, Lowari Law, supra note 126, at 6 . In cases of exclusion, the kris scrutinizes the evidence of defilement and publicly pronounces the defendant as either clean or marime.

144. GROPPER, supra note 79, at 84-85; Lee, Kris, supra note 51, at 28. According to Jeatran, Social Control, supra note 139, at 26, some young Gypsy men in the United States ridicule the formal oratory and prefer telephone "conference calling" to settle their disputes, perhaps as a preliminary step to a divano.

145. C.-H. Tillhagen, V. Conceptions of Justice Among the Swedish Gypsies, 38 J. GYPSY LORE SOC'Y 127, 131 (1959) (quoting Romani source on honesty among Gypsies) [hereinafter Tillhagen, V]. But see Yoors, Lowari Law, supra note 126, at 13 (accused tries to elude questions and attempts to make the crime seem less serious). The Roma present their own case, husbands answering for their wives. Yet, spokesmen, the equivalent of lawyers, can be employed to plead the case for the parties. They may be young men who 
power of the dead with an oath. If the witnesses must swear an oath, an altar of justice consisting of icons of the clans present is erected. ${ }^{146}$ In complex situations, the judge may ask for expert opinions from tribal chiefs or the elders. Nonetheless, only the judge decides guilt and punishment. ${ }^{147}$

The judge declares the verdict in public to those who are present. In former times, if the accused Rom was found guilty, a married Gypsy woman was symbolically called on to tear a piece of cloth from her dress and throw it at the Rom, but this ritual is no longer practiced. If the accused is found innocent, there is a celebration and an oath of peace is sworn. The decision of the kris is final and binding. ${ }^{148}$ Even in countries such as Spain and the United States, where the Roma are considered by some gajikane scholars to be semi-assimilated, the verdict of an official state trial is not final: a kris will still be held. Beyond its judicial function, the kris plays an important role in maintaining the customs of the Gypsy people. ${ }^{149}$

Recent developments suggest the possibility of cooperation between the Romani and American judicial systems. By March 1987, local Roma in Southern California had reportedly established eighteen territorial jurisdictions, each with its own judge. The idea was that these kris would receive case referrals from the California state courts of civil and domestic disputes involving only Gypsies. The local kris would then refer nonbinding recommendations back to the California courts. ${ }^{150}$ In another recent development, over two hundred Roma gathered for an advisory kris in Houston to discuss improving the rights of divorced women under the Romani legal system, to keep pace with developments in American law and to remove the incentive for Gypsy women to appeal to the American legal system for a

test their rhetorical skills and their capacity for leadership. GROPPER, supra note 79, at 82-84; MCLAUGHLiN, supra note 58, at 23-24; Yoors, Lowari Law, supra note 126, at 3. Jeatran, Social Control, supra note 139, at 20, describes two exceptional cases in which non-Gypsies attended a kris: a local gajikano attomey acting as informal counsel in a child custody matter and a California social worker appearing at the Gypsies request for informational purposes.

146. CLÉBERT, supra note 44, at 130; YOORS, GYPSIES, supra note 42, at 177-79; see also Yoors, Lowari Law, supra note 126, at 17 (describing solemn oath, solax, administered when no decision can be reached). According to GROPPER, supra note 79, at 83 , a new trial must be held if the krisnitorya cannot reach a decision. Parties may also swear an oath before the kris, agreeing to abide by the decision. SUTHERLAND, supra note 29, at 134-35.

147. CLÉBERT, supra note 43, at 130 . As long as the kris has not proceeded beyond hearing from the witnesses and final instructions, either the plaintiff or the defendant may request permission to settle the case outside the kris. Yoors, Lowari Law, supra note 126, at 14. After hearing from both sides, but before giving the decision, an impartial elder may emerge to attack the litigants' arguments. Id. at 16 . Among the Lovara, if a judge appears to be wrong on a point of law, the council can ask him to justify his decision. Id. at 4.

148. SuTHERLAND, supra note 29, at 132. But see Yoors, Lowari Law, supra note 126, at 5 (observing that appeals are allowed among European Lovara, but severely frowned upon); see also CLÉBERT, supra note 44 , at 130 (oath of peace).

149. Cf. CLÉBERT, supra note 44, at 130-31; GROPPER, supra note 79, at 180.

150. Lee, Kris, supra note 51 , at 32 . We were not able to confirm that this procedure, if approved, was ever implemented, but the Gypsies' desire for any affiliation with the American court system is unprecedented. Telephone Interview with Barry A. Fisher, Attorney-at-Law, Los Angeles, Cal. (Mar. 8, 1993), who has represented Romani interests in the past. 
stronger remedy. ${ }^{151}$ These developments could conceivably lead to the establishment of standing Romani courts within each state. ${ }^{152}$ But it is unclear how the American legal system would respond to such a system, since it does not recognize Romani law as binding. Gypsies, too, might find it difficult to abandon their traditional distrust of American courts.

\section{Legal Sanctions}

The kris imposes punishment according to the seriousness of the offense. The death penalty, once an acceptable option, is now virtually unknown ${ }^{153}$ - possibly because of the Gypsies' fear of spirits and belief that the angry ghost of the deceased will take revenge upon the executioner. In times when the death penalty was still employed, the entire community would participate in the execution to prevent revenge by the spirit. The Roma seemed to feel a joint undertaking was safer, although today they rarely test this belief. ${ }^{154}$ Nowadays, the kris relies primarily on such sanctions as fines, corporal punishment, and banishment. The responsibility to pay a kris-imposed fine, called glaba, falls collectively on the wrongdoer's lineage. ${ }^{155}$ Corporal

151. Lee, Kris, supra note 51, at 32-33. Hancock, who participated in a Houston kris that dealt with the topics of child support and divorce, reports:

The issue was that divorced women were going to the gajikane dukaturya (non-Gypsy lawyers)

for relief because the kris wasn't satisfactory. The main concern was that by going to the gaje,

the power of the kris was being undermined. In order for it to maintain its strength (krisaki putyerya) it would have to provide better resolutions to divorcees (divorced according to

Romani tradition, not American tradition). So control cuts both ways. The decision was to

enforce more responsibility on the part of the father.

Letter from Ian F. Hancock, Romani Union, Professor of Linguistics, University of Texas, to Walter $O$. Weyrauch, at 5 n.46 (July 1990) (on file with authors) [hereinafter Hancock, Letter].

Hancock also describes a kris in California that debated the issue of whether Romani women could wear jeans. He adds that European Roma think that this topic is too trivial to require a kris and that a divano would have been more appropriate. See also SUTHERLAND, supra note 29, at 131-32 (divano involving many vitsi may decide matters of general policy). These consultative functions of the kris or divano resemble the Weistum in medieval Germany, in which learned authorities gave legal advice. In the contemporary American context, these functions resemble the opinions of the attorneys general. On the divano, see supra notes $126-27$ and accompanying text.

152. Lee, Kris, supra note 51 , at 34 .

153. ClÉBERT, supra note 44 , at 130.

154. GROPPER, supra note 79, at 100-02. Gropper also notes that a permanent sentence of marime is seen as equivalent to a death sentence; the permanent outcast, in fact, often commits suicide. A death sentence thus becomes unnecessary, and the sentence of marime also provides a form of sanctuary against revenge of the spirit. Id.; see also FRASER, supra note 28, at 243 (fear of spirits). Reisman comments that interviews with Gypsy defectors could be the subject of an interesting follow-up study. Reisman, Comment, supra note 46, at 404. In Canada, resettling outside the Gypsy community has occurred. See infra note 160.

155. LIEGEOIS, supra note 52, at 76-77. In her study of Gitano urban populations, San Román, supra note 101, at 192-93, divides "wrongs" in Gypsy society into two categories: (1) wrongs that have consequences for the wrongdoer's lineage and the victim's lineage, and (2) wrongs that have consequences only for the wrongdoer and the victim's lineage. The first category of wrongs consists of serious offenses like murder, bloodshed, serious assault and "naming the dead" (insults directed toward a deceased relative). Bloodshed and assault may or may not be avenged. These wrongs are generally dealt with on the spot by a fight among members of the respective lineages present. However, murder and "naming the dead" are crimes that must be addressed by the kris Romani. Murder is extremely rare because of the Gypsies' fear of ghosts. 
punishment, rarely employed today, is typically used only in cases of a wife's infidelity.

A sentence of marime, or banishment, is today considered the most severe punishment. Marime stigmatizes all wrongdoers as polluted and justifies their expulsion from the community. No one will eat with them. If they touch an object it must be destroyed, no matter what the value. Nobody will even attempt to kill them, for fear of contamination. When they die, no one will bury them, and they will not have a funeral. They will soon be forgotten. ${ }^{156}$ No marriages are arranged for those stigmatized as marime, and without marriage in Gypsy society one's economic and social life is over. ${ }^{157}$ In other words, permanent banishment is the equivalent of social death. Such punishment is rare and used only for serious crimes such as murder. An escape into gajikano society is not an alternative for the banished wrongdoer, however. Disdain for the non-Gypsy world, acquired in early infancy, maintains its hold over most Roma even after their expulsion from the community.

A temporary marime sentence may be imposed for less serious crimes. If a Gypsy steals from another Gypsy, for example, the thief is publicly shamed and banished from the community until he or she has repaid the victim. The kris may impose a form of "community service" and require the marime Rom to work for an indefinite time without pay in order to compensate Gypsy society for violating the taboo of stealing from another Gypsy. Temporary sentences of marime are also imposed for offenses such as familiarity with the gaje or failure to pay a debt on time. ${ }^{158}$

The entire Gypsy community is responsible for enforcing sanctions. Gypsies have no police or prisons; they have no "law enforcement" in the gajikano sense. Peer pressure fanned by gossip and communal knowledge of the verdict tend to ensure the wrongdoer's compliance. ${ }^{159}$ The Gypsy community may place a curse on the guilty party to insure that he or she accepts the chosen punishment, and it appears that this practice is still effective. Only in rare cases, when the Roma have difficulty enforcing a

The second category of wrongs involves mostly sexual offenses such as rape and incest. In Gitano society, the male is held primarily responsible for these wrongs. Women are held less accountable because of their assumed inferiority. Nonetheless, depending on the group, infidelity may carry serious penalties for a female. QUINTANA \& FLOYD, supra note 108, at 35, report that among the Gypsies in Spain punishments may include facial disfigurement and other mutilation, public beatings, and death.

156. CléBERT, supra note 44, at 124-25 (quoting Mateo Maximoff). A person who receives a permanent sentence of marime is treated very much like someone in today's society who is diagnosed with an infectious disease. See also SUTHERLAND, supra note 29, at 98-99. Hancock reports that a Rom with AIDS committed suicide in New York City three years ago because of the shame (lajav) associated with the illness. Hancock, Notes, supra note 31, at 6 n.66.

157. Cf. SWAY, supra note 52 , at 118.

158. TRIGG, supra note 72 , at $70-71$.

159. SWAY, supra note 52, at 119; YOORS, GYPSIES, supra note 42, at 174; see also Anne Sutherland, Gypsies, The Hidden Americans, SOCIETY, Jan.-Feb. 1975, at 30 (discussing gossip as means of social control). 
judgment by the kris, do they turn to the gajikano penal system. The kris may ask the gajikane authorities to arrest the renegade, and if necessary will employ false charges as a basis for the arrest. At this point, the wrongdoer will usually accept the punishment and the charges will be dropped. Should the wrongdoer persist, however, he or she might be forced to endure a gajikano court trial. ${ }^{160}$

\section{Conflict Between Host Legal System and Gypsy Law}

Gypsy sources consistently assert the superiority of their legal system, noting the following three elements:

(1) Gypsy law acts as a cohesive force serving to protect Gypsy interests, rights, traditions, and ethnic distinctiveness; (2) Gypsy law is more democratic than any other law because it does not discriminate against individuals without financial or other influence; and (3) because Gypsy law has maintained its basic form, even though older methods of punishment have given way largely to banishment or social ostracism, it must be more nearly perfect than other laws, which appear to be undergoing constant change. ${ }^{161}$

These attitudes have an impact on how the Gypsies approach conflicts with the gajikano legal system. Romaniya has no equivalent to the concept of conflict of laws. Gypsy law is self-contained and cannot incorporate rules of a foreign legal system. Consequently, severe clashes of inherently incompatible legal notions occasionally occur. The gajikano legal system is equally insular so far as romaniya is concerned. But unlike the gaje who know nothing about romaniya, Gypsies are necessarily aware of non-Gypsy law. They may tolerate it or violate it, all the while maintaining that their own law is the only true law.

Studies indicate that the most frequent violations of the host countries' laws by Gypsies are theft and fraud. ${ }^{162}$ Some have interpreted this

160. GROPPER, supra note 79, at 103-05; MCLAUGHLIN, supra note 58, at 24; SwAY, supra note 52, at 82. According to BLOCK, supra note 44 , at 172 , in former times the defendant who did not show up at the kris became an outlaw. There were special signs (patrin) that this Gypsy was being hunted. Any Rom who saw the signs was obliged to help in the search. An accused who resisted when caught could be shot. Gajikane authorities who investigated would learn only of a tragic accident. The potential ineffectiveness of the kris under contemporary conditions in Eastern Canada is discussed in Lee, Kris, supra note 51, at 31-32 (describing how Rom can evade Gypsy law and resettle outside Gypsy communities). Lee points out that the kris remains effective in the United States.

161. QUINTANA \& FLOYD, supra note 108, at 38-39. Although the quotation relates to Gitanos in Spain, it seems to represent the ways most Romani people feel about their laws. Quintana and Floyd merely convey the subjective ideas of their sources; they express no opinion on the accuracy of these views. The authors also note that it is extremely difficult to get Gypsy informants to discuss their laws. Id. at 37-38. Fully one-third of the sample refused to answer. Typical responses were: "I do not think of these things. Are you being paid to find out?' 'It is better not to answer. Who knows what may come of it."'

162. San Román, supra note 101, at 188-89. San Román's work deals with the urban Gitano 
phenomenon as a reflection of a Gypsy penchant for lawlessness. The Gypsies, however, have no moral objections to these activities so long as one does not victimize another Gypsy, causes no physical harm, ${ }^{163}$ and takes no more than is necessary to survive. ${ }^{164}$ Thus what is permissible under romaniya may be criminal under the host legal system. Other sources have argued that, to a Gypsy, stealing from a gajo is even praiseworthy because of the skill and courage involved. Moreover, subsistence theft may be permitted under Gypsy law because the gaje are seen as overindulgent and exploitative; thus there is nothing wrong in taking from them what they do not need. ${ }^{165}$

So-called swindling is considered a common means for Gypsies to make a living. ${ }^{166}$ There is a danger, however, that the dominant culture can use the term "swindling" ethnocentrically to stigmatize minority groups. A host culture may tolerate essentially fraudulent advertising and sales practices-for example, in so-called clearance sales and "bait-and-switch" schemes-as long as they are employed by people who are perceived as members of the dominant culture and who meet the minimum standards of local custom. ${ }^{167}$ When ethnic minorities such as Gypsies use comparable sales techniques, the doctrine of caveat emptor no longer applies and the whole group becomes

population. According to Hancock, Diaspora II, supra note 59, at 654 , subsistence stealing largely occurs in the United States among recent European Gypsy immigrants. Most American Roma abhor this behavior because it results in stereotyping of the whole population. It should be noted that much of the information on alleged Gypsy criminality has been collected by law enforcement agencies, and this reflects the perspective of the host legal system.

Thomas Acton, as quoted in Ian Hancock, The Roots of Inequity: Romani Cultural Rights in Their Historical and Social Context, IMMIGRANTS \& MiNORITIES, Mar. 1992, at 3, 7, has maintained that the emphasis on Gypsy crime is misplaced: "Compared with the massive record of murder, theft, kidnapping and other crimes by non-Gypsies against Gypsies (throughout history), Gypsy crime against non-Gypsies pales almost into insignificance, so that to prioritize the study of the latter over the former shows a twisted sense of values." For example, more than 600 Gypsy children were kidnapped by the Swiss Pro Juventute program between 1926 and 1973. Thomas W. Netter, Swiss Gypsies: A Tale of Vanishing Children, N.Y. TIMES, June 9, 1986, at A9. The scandal resulted in a formal apology by Alphons Egli, President of Switzerland. After the fall of the Ceauşescu regime in Rumania, persecution and poverty left thousands of Gypsy children homeless or housed in orphanages. Kathleen Hunt, Romania's Lost Children: A Photo Essay by James Nachtwey, N.Y. TiMES, June 24, 1990, § 6 (Magazine), at 28; see also Pavel, supra note 2, at 12 (detailing Gypsy persecution under new government). Efforts of U.S. citizens to adopt some of these children were thwarted because parental consent was missing or flawed. Battle over Romanian Adoptions Continues, 70 INTERPRETER RELEASES 561 (1993).

163. San Román, supra note 101, at 188-89.

164. YOORS, GYPSIES, supra note 42, at 34; see also Fisher, Gypsy Minorities, supra note 101, at 51-52.

165. TRIGG, supra note 72, at 72-73. For a detailed discussion of Romani rules on theft, see Linnet Myers, Circling the Wagons, CHI. TRIB., Dec. 27, 1992, at C1.

166. San Román, supra note 101, at 189. See the account of a minor fraud perpetrated by a Gypsy in LEE, AUTOBIOGRAPHY, supra note 29, at 26-27. The Rom's explanation in this case was, "The non-Gypsy is a fool" ("Gazho si dilo").

167. ARTHUR A. LEF, SWINDLING AND SELLING 134-37 (clearance sale), 143-46 (bait-and-switch) (1976). In discussing his theory that swindling and selling are based on essentially similar dynamics, Leff contends that the so-called Gypsy switch is related to most forms of selling. The "Gypsy switch" involves an exchange in which something of value is offered but, by a sleight of hand, something of no or little value is substituted. Leff suggests that in successful selling, particularly advertising, the seller tends to promise more than he can déliver. Leff concludes that somehow a "switch," in other words, a form of confidence game, has been pulled. Id. at 12-13, 155-57. 
stigmatized. Thus, claims of Gypsy criminality must be examined in comparison to the host culture which criminalizes those activities. While the dominant culture may overlook its own members' transgressions, it notes the Gypsy practice with indignation and may even prosecute it. The host society's occasional leniency toward such Gypsy behavior may be due not to ideas of fairness but to difficulties in communicating with alien people or limited resources. Realistically, prosecution of Gypsies often results not from their violation of the formal laws of the host culture (which members of the host culture may also violate), but instead from Gypsies' adherence to their own informal laws which conflict with the host nation's informal laws.

Host countries often view fortune-telling, a traditional occupation of Gypsy women, as swindling. Not practiced among the Roma themselves, fortune-telling involves the use of ritual and charms meant to dazzle the gajikano customer. Many host countries have reacted to this traditional Gypsy practice by banning fortune-telling, although authorities often do not enforce these laws against the Gypsies with the same stringency they do other laws. ${ }^{168}$ Indeed, the dominant culture has reluctantly begun to recognize that its own cultural values are not necessarily absolute. Cultural defenses have been increasingly permitted in American trials. ${ }^{169}$ In addition, some courts have considered the issue under gajikano law of whether a fortune-teller who believes in magic and ancient healing powers can form a criminal intent. ${ }^{170}$ Thus the American host legal system has taken some steps to accommodate Gypsy practices.

The issue of fortune-telling is actually more complex than it appears. On the one hand, Gypsies believe in their magical powers, as exemplified by their use of curses and the practice of fortune-telling. On the other hand, they practice fortune-telling not among themselves but only for the benefit of gaje.

168. Roma have successfully challenged state laws banning fortune-telling. See, e.g., Spiritual Psychic Science Church of Truth v. Azusa, 703 P.2d 1119 (Cal. 1985); see also Dan Morain, State High Court Rules Out Ban on Fortune-Tellers, L.A. TIMES, Aug. 16, 1985, pt. 1, at 3. On fortune-telling, see generally LEE, AUTOBIOGRAPHY, supra note 29 (autobiographical account containing illustrations and explanations of tarot cards); SUTHERLAND, supra note 29, at 85-89; TRIGG, supra note 72, at 74-75; San Román, supra note 101 , at 189.

169. See, e.g., Mull v. United States, 402 F.2d 571, 575 (9th Cir. 1968), cert. denied, 393 U.S. 1107 (1969) (dictum) (noting claim that Native American may lack criminal intent because of cultural beliefs); State v. Curbello-Rodriguez, 351 N.W.2d 758, 770 (Wis. Ct. App. 1984) (Bablitch, J., concurring) (stating that sexual customs of Cuban culture should be considered when sentencing for rape); People v. Kimura, No. A-091133 (Los Angeles City Super. Ct. filed Apr. 24, 1985), cited in Spencer Sherman, Legal Clash of Cultures, NAT'L L.J., Aug. 5, 1985, at 1 (considering Japanese custom in murder case); see also Paul J. Magnarella, Justice in a Culturally Pluralistic Society: The Cultural Defense on Trial, J. ETHNIC STUD., Fall 1991, at 65; Note, The Cultural Defense in the Criminal Law, 99 HARV. L. REV. 1293 (1986); Rorie Sherman, "Cultural" Defenses Draw Fire, NAT'L L.J., Apr. 17, 1989, at 3.

170. Azusa, 703 P.2d at 1126 ("[S]ome persons believe they possess the power to predict what has not yet come to pass. When such persons impart their beliefs to others, they are not acting fraudulently."). On the difference between advising and fortune-telling, see Ian F. Hancock, The Gypsies, Indian World Citizens, in Global MigRation of INDIANS: SAGA OF ADVENTURE, ENTERPRISE, IDENTITY AND INTEGRATION (Jagat K. Motwani ed., forthcoming winter 1993-94) (manuscript at 5, on file with authors) [hereinafter Hancock, World Citizens]. 
Thus their beliefs in their own magical powers may appear to stand on shaky ground. This apparent paradox has a relatively simple explanation. The concept of fortune-telling contains several independent elements that are misleadingly grouped together. One element is foretelling the future. Perhaps because of its inherent dangerousness, this activity is not practiced internally among Gypsies. Another element, according to Sanskrit sources, relates to "making well" and healing powers, which the Gypsies do practice among themselves. ${ }^{171}$ The healing elements of fortune-telling are reflected in Gypsy references to fortune-telling as "advising." Both elements are based on a belief in magic, although they often appear to the non-Gypsy world as scams.

In addition to fortune-telling and healing, Gypsies engage in deliberately fraudulent practices. In Spain, Gypsies have been reported to misrepresent goods and trade unfit horses. In the United States, there have been reports of used car scams and home repair deceptions. These scams reflect the disdain that many Gypsies are said to have for the gaje. ${ }^{172}$ In the United States, many Gypsies consider welfare to be the ultimate scam, as it proves the naivete of the gaje. ${ }^{173}$ One study gives a detailed account of the strategies Gypsies use to obtain benefits from welfare agencies. ${ }^{174}$ Gypsy women aggressively negotiate with social workers, while the men stand by passive and mute, often pretending to be mentally retarded and unemployable. One Gypsy explained how he was able to score low on a test:

The trick is never to protest anything but act like you are doing everything right and are, you know, simple-minded and goodhearted about it. Anything she asks me I just give some wrong answer. For instance there was a picture of this doll, and I was supposed to connect the arms and legs. Well I put the legs in the armholes and the arms below. She kept trying to help me but I stuck with that like I was sure it must be right. ${ }^{175}$

Under Gypsy law, theft and fraud are crimes only when perpetrated against other Gypsies. These actions severely violate the basic Romani tenets of

171. Hancock, World Citizens, supra note 170 (manuscript at 5) (noting Sanskrit sources of fortune-telling).

172. San Román, supra note 101, at 189 (Spain); MCLAUGHLin, supra note 58, at 51-56, 71 (United States). Since most of these scams are widely practiced by non-Gypsies as well, and to some extent condoned, the focus on the Gypsies may be an expression of xenophobia. See HaNCocK, PARIAH SYNDROME, supra note 1, at 115-28 ("Anti-Gypsyism"), 143-62 ("Media Representation of Gypsies").

173. LIEGEOIS, supra note 52, at 82 . Gypsies may not realize, however, that in some cases they may be entitled to public assistance and thus are not committing a crime under host country law.

174. SUTHERLAND, supra note 29 , at 75-85.

175. Id. at 81; see also SWAY, supra note 52, at 11. Field research of this type presents a professional dilemma. The information gained is likely to become known to law enforcement and welfare agencies who then are prone to use it to the detriment of those attempting the "revealed" practices. On the other hand, if a researcher is not able to obtain the confidence of Romani informants, the information is worthless and only adds to a growing pool of similar "evidence." SUTHERLAND, supra note 29, at ix-x, xii. 
mutual cooperation, ${ }^{176}$ and may result in a kris and stringent sanctions. When the victim is a non-Gypsy, however, a kris and sanctions are unlikely to result. To that extent, the kris is ethnocentric because it is limited to parties and participants who are Gypsies. The gaje may take no part in these proceedings. Victimized Gypsies may be sued and have standing to complain in gajikane courts. Yet victimized non-Gypsies may only sue in non-Gypsy courts. These victims have no standing to complain by way of a kris. In other words, Gypsies would have to invoke the jurisdiction of Romani courts on behalf of non-Gypsies, a procedural impossibility because romaniya is only meant to protect the Gypsy community. No Rom would be likely to accept a judgeship in a case that an outsider attempted to bring.

It is imaginable, although probably more hypothetical than real, that in instances of extreme misconduct toward non-Gypsies, the jurisdiction of a kris could be invoked. The complainants, however, would be other Roma who were endangered or subjected to persecution, and thus victimized, as a result of the reckless conduct of a fellow Gypsy toward gaje. Even under these circumstances, though, a kris might not occur because community members fear the attention it could draw. Substantively, the crime involved would be reckless endangerment of other Gypsies, rather than violation of the rights of the gaje.

The host country and Gypsy systems inevitably conflict. Nevertheless, host authorities often do not interfere with Gypsy society and in many respects are unequipped to deal with Romani culture when conflict occurs. But local gajikane authorities do intervene in cases of serious crimes, like murder. Even then, Gypsy law has a way of asserting itself. ${ }^{177}$ A study of urban Gitano populations provides two examples. ${ }^{178}$ In the first, a Gypsy murdered another Gypsy and was sentenced to death by a gajikano court. While in prison, the convicted Gypsy died after eating food that other Gypsies had brought to him. This may be one of the rare instances in which a Romani population imposed and executed a death sentence. On the other hand, the convict may have eaten the poisoned food willingly, in order to commit suicide. In either case, the Romani law prevented the gajikane authorities from executing their death sentence. Gypsy law prevailed over the law of the host country without the Spanish authorities' knowledge.

The second example in the study describes cases in which a Romani chief has committed a crime under gajikano law. The elders will decide that, if there is a police investigation, a younger member of the group, usually the son of the actual culprit, will accept blame for the crime. This subterfuge protects the

176. The fundamental spirit of cooperation is exemplified by the Romani word pal, meaning close friend, brother, or accomplice, now in American usage but of Sanskrit origin. See WEBSTER's THIRD, supra note 31 , at 1622 .

177. See Fisher, Gypsy Minorities, supra note 101, at 51.

178. San Román, supra note 101 , at 190. 
chief, who is more important to the group as a whole. If the gaje imprison the young man, members of the group will visit him in prison and give him any convenience possible. By the time of his release, he will have gained the gratitude and respect of the group. As in the first case, Gypsy law has effectively circumvented the host country's justice system.

According to a study of the Gypsy population in Sweden, if a Gypsy is called before a gajikano tribunal, a crowd of Gypsies escorts the individual. In so doing, the Gypsies hope either to show support for the accused or to influence the judge. If neither works, the Gypsies may utter magic curses to interfere with evidence taking or sentencing. Gypsy women disrupted one trial by chewing bread, spitting it out in their palms, and kneading the bread as they whispered curses. One Gypsy commented that at a gajikano trial "we tell lies, we make up stories, we pretend to forget things, so that in the end no one knows which is front and which is back!"179

Most Roma learn their native language, Romani, and may use it strategically to create confusion and indirection. ${ }^{180}$ Spoken by millions of Gypsies, Romani is known to only a few researchers. ${ }^{131}$ In addition, Gypsies from some groups may have several names: a secret name used in rituals, a name given at baptism and used among brethren, and one or more names reserved for the gaje. According to a study written by a non-Gypsy, Gypsies do not record births, marriages, or divorces; they do not file income taxes; they do not pay property taxes; they rarely maintain bank accounts; and they often obtain credit for short periods of time under aliases. ${ }^{182}$ These practices would make Gypsies difficult to track and would prevent authorities from gaining access to information. Romani sources, however, dispute such stereotypes. ${ }^{183}$

179. Tillhagen, $V$, supra note 145 , at $131-32$.

180. CLÉBERT, supra note 44, at 191 (noting Sanskrit origin of Romani); Beverly N. Lauwagie, Ethnic Boundaries in Modern States: Romano Lavo-Lil Revisited, 85 AM. J. SoC. 310, 321 (1979); Carol Silverman, Everyday Drama: Impression Management of Urban Gypsies, 11 URB. ANTHROPOLOGY 377 , 382-83 (1982) [hereinafter Silverman, Impression Management]. The Romanichals, Gypsies of English origin, have adopted English surnames, such as Ronald Lee, while the Vlax group originating from Wallachia uses Romani names in addition to surnames common in the host country. Hancock, Gypsies, supra note 60, at 442. For example, Ian Hancock's Romani name is O Yanko Le Redžosko. 1 WHO's WHO IN AMERICA 1427 (47th ed. 1992-1993).

181. YOORS, GYPSIES, supra note 42 , at 7 ("When approached directly, they show a total disregard for consistency and may become totally incomprehensible about any matter they do not want to discuss ...."). Some characteristics of Romani may facilitate hiding information from the rare outsiders who understand the language. It contains 'loan' words from many countries enabling the speaker to express the same content in different ways. GROPPER, supra note 79, at 84-85.

182. MCLAUGHLIN, supra note 58 , at 78 ; see also CLÉBERT, supra note 44 , at $166-67$ (discussing multiple names).

183. The Romani sources note that numerous Gypsies adhere to the laws of their host countries, pay taxes, are professionals, authors, or entertainers; and that Gypsies regularly have a lower violent crime rate than their hosts. See, e.g., HANCOCK, PARIAH SYNDROME, supra note 1, at 111-14 (criticizing authors of law enforcement orientation). Hancock also gives an account of the literature and media reporting that have reflected negative stereotyping of Gypsies. Id. at 115-62; see also supra note 162 . Gypsies generally do not engage in crimes of violence (murder, rape, robbery, and assault and battery) in order to gain money. MCLAUGHLIN, supra note 58, at 86-87. Hancock stresses that prominent respected Romani Americans are known within their Gypsy communities, but avoid drawing attention to their ethnic origin. Hancock, 
Gajikane legal authorities consequently face unusual problems obtaining evidence and have often chosen to ignore the Roma rather than prosecute them for minor offenses. Unfortunately, in some cases where the police have become active, they have seriously violated the Roma's civil rights under American law. ${ }^{184}$ Such violations appear to be due not merely to frustration and difficulties in obtaining evidence, but also to the assumption that Gypsies are so universally despised that nobody will come to their aid. The police are more likely to engage in official misconduct when they know that Gypsies do not customarily complain to non-Gypsy authorities about abuses and do not seek legal redress from the host system. ${ }^{185}$ Gypsies believe they cannot expect sympathy or even neutrality from the host country, ${ }^{186}$ an attitude that undoubtedly affects some of their conduct.

Although Gypsy law sometimes conflicts with statutory or common law, it is virtually impossible for it to violate the United States Constitution. The

Diaspora II, supra note 59, at 653-54.

184. On June 18, 1986, the Spokane Police Department and Sheriff's Office raided a local Gypsy home without a proper search warrant. The officers seized $\$ 1.6$ million in cash held in trust for the Gypsy Church of the Northwest and more than 600 pieces of jewelry. The seized property has been ordered to be returned but is still partly unrecovered. Members of the family, including women and young children, were body searched. The state supreme court declared that the police had engaged in "egregious behavior." State v. Marks, 790 P.2d 138, 142 (Wash. 1990).

In a subsequent federal suit for civil rights violations, which is still pending, the Gypsies sought $\$ 40$ million in damages. The city and county admitted liability and agreed that they would accept a ruling by Judge Robert McNichols regarding the amount of damages, provided that the Gypsies agreed not to seek punitive damages. Ian Hancock was asked to testify as an expert witness on the damage caused by the illegal police search. In addition to losing the unretumed property, the whole family has become marime (outcasts to other Roma), because the family's chief, Grover Marks, lost credibility and because its members have been contaminated through physical contact with gajikane men. The marital prospects of the young Romani girls, in view of the intimate body search by the police officers, look very dim. The settlement is now being questioned because Judge McNichols, who heard the evidence, died, and the case has been reassigned to a new judge. For details on this case, see Claudia G. Dowling \& Linda Gomez, Gypsies, LIFE, Oct. 1992, at 47-53; Timothy Egan, Police Raid and Suit Open Window into Gypsy Life, N.Y. TIMES, Apr. 14, 1992, at A16; Bill Morlin, New Judge Takes Over Gypsy Case: McNichols Too Ill To Continue, Spokane Spokesman ReV., Dec. 16, 1992, at Al; Bill Morlin \& Rebecca Nappi, Gypsy Daughters Say 1986 Search Violated Culture, SpoKane SpOKESMaN Rev., Sept. 18, 1992, at Al.

The Spokane litigation is a rare instance of Roma invoking the jurisdiction of host courts. The personality of Judge McNichols may have influenced the family in their decision to sue in the American system. He was a highly respected jurist and known for his compassion. See Bill Morlin, U.S. District Judge Robert McNichols Dies, SPOKANE SPOKESMAN REV., Dec. 22, 1992, at Bl.

185. According to HANCOCK, PARIAH SYNDROME, supra note 1, at 105-06, local laws discriminating against Gypsies were still in effect in 1987. Despite some changes in recent years, Gypsies remain reluctant to bring their grievances to gajikane courts. If these discriminatory laws are not challenged, however, they may remain in effect indefinitely. For a contemporary illustration, see N.J. STAT. ANN. § 40:52-1 (West 1991) ("The governing body may make, amend, repeal and enforce ordinances to license and regulate: ... k. Roving bands of nomads, commonly called gypsies .....').

Hancock states that attempts to strike such laws have been successful but slow. He reports that when these laws were brought to the attention of the Federal Office of Civil Rights in 1986, the Office said that the term "living like a Gypsy" referred to all those living a nomadic life and was not targeted against the Gypsies as an ethnic minority. Hancock, Diaspora II, supra note 59, at 647-48. For corresponding problems under English law, see FRASER, supra note 28, at 2-7.

186. In national opinion polls taken both in 1964 and 1989, Gypsies had the lowest social standing of 58 ethnic minorities included in the surveys. See Tamar Lewin, Study Points to Increase in Tolerance of Ethnicity, N.Y. TIMES, Jan. 8, 1992, at A12. 
Constitution primarily restrains the activities of state actors, not private parties or autonomous legal systems. Even when Gypsy law establishes repressive regimes or violates what would be called due process in the state system, it cannot be considered "unconstitutional." These actions may be tolerated by authorities because Gypsy law is not visible to the state or because the state does not perceive Gypsies as "lawmakers." The situation is analogous to that of the informal rules established within the family which are authoritarian and violate democratic ideals, but nevertheless go unchallenged by the state. ${ }^{187}$ The state may occasionally try to regulate what goes on in the family, just as it may also try to regulate Gypsy practices such as fortune-telling. In either case, however, the regulations are likely to be held to violate constitutional rights. ${ }^{188}$ Thus, the state is practically incapable of regulating at this level of private lawmaking.

\section{E. Previous Attempts at Theory}

\section{Some Trends in the Nonlegal Literature}

Most scholars do not analyze Gypsy law's legal significance but rather its general cultural significance. Their scholarship focuses on customs, traditions, norms, and rules. As a consequence, it does not devote significant attention to legal institutions as such. Even if the literature refers to legal terms, such as "procedure" and "courts," these terms inevitably have connotations different from those used in law. ${ }^{189}$

The literature has sometimes described the Gypsy mode of life as "primitive,"190 or has stressed the alleged illiteracy of the Gypsies. ${ }^{191}$ These characterizations, however, have little analytical value. The often incomprehensible conduct of the non-Gypsy world, as seen by a Gypsy, could

187. See Schmideberg, supra note 10.

188. Compare, e.g., Griswold v. Connecticut, 381 U.S. 479 (1965) (holding Connecticut statute prohibiting use of contraceptives unconstitutional as violating right of marital privacy) with Spiritual Psychic Science Church of Truth v. Azusa, 703 P.2d 1119 (Cal. 1985) (holding city ordinance prohibiting fortune-telling violative of California Constitution's freedom of speech clause). Without a stimulus such as oppressive state legislation, however, it is unlikely that members of the Gypsy community will bring complaints.

In many respects, private lawmaking, including Gypsy law, is beyond the practical reach of any state authority. Government does not have the economic resources, personnel, and expertise to regulate on this amorphous level. This inactivity is due to a lack of power and knowledge and not necessarily an intent to foster private lawmaking. But see Reisman, Comment, supra note 46, at 409-10.

189. See generally Thomas A. Cowan, What Law Can Do for Social Science, in LAW. AND SOCIOLOGY: EXPLORATORY ESSAYS 91 (William M. Evan ed., 1962).

190. See, e.g., C.-H. Tillhagen, Conception of Justice Among the Swedish Gypsies, 37 J. GYPSY LORE Soc'Y 82, 83 (1958) [hereinafter Tillhagen, II]. In recent years, characterization of population groups as "primitive" is found less frequently in the literature. See, e.g., Dell Hymes, The Use of Anthropology: Critical, Political, Personal, in ReINVENTINg ANTHRopology 3, 27 (Dell Hymes ed., Vintage Books 1974) (1972) (criticizing use of the term "primitive").

191. See, e.g., SWAY, supra note 52, at 124. 
with equal justification be characterized as "primitive," in the sense that the gajikane values may appear to be rudimentary and irregular to anybody who does not share them. Similarly, one could maintain that the non-Gypsies are illiterate because they are ignorant of the Romani language and of fundamental skills needed for effective communication, as seen from a Gypsy perspective. ${ }^{192}$ In other words, from a Gypsy's point of view the gaje are uncivilized.

In so-called primitive societies, as characterized by Jonathan Turner, laws are typically not recorded, and are steeped in custom, religion, and tradition. Yet, there are traces of a distinction between substantive and procedural law. ${ }^{193}$ In applying the characteristics ascribed by Turner to primitive legal systems, substantive law in Gypsy society consists largely of the marime taboos, which specify pure and impure acts and things. Procedurally, enforcement occurs through informal social control via the divano, the kris, and the dreaded marime sanction. Mediation and the courts, such as the divano and the kris, are summoned in an ad hoc fashion as conflicts arise, and owe their existence only to the specific case. At least two clearly identifiable legal actors participate within these "courts": judges or krisnitorya, who decide on both facts and law; and the parties, who have sworn an oath to respect the authority of the krisnitorya.

Although the Roma's legal system seems in many ways to fit into this scheme, Turner's primitive legal systems are generally "typical of hunting and gathering and simple agrarian societies."194 The Gypsies' dependence on the dominant host economy makes them different from other societies; their need for ongoing relations with the gaje is an essential feature of their culture. ${ }^{195}$ This dependence is not confined to economic matters. The threat of gajikane authorities and their legal system reinforce the Romani way of life and culture. These unique characteristics of the Roma invite comparisons with other forms of private lawmaking that are neglected in legal scholarship. Yet the link between tribal law and private lawmaking seems to be insufficiently noted in the nonlegal literature as well.

Many researchers have attempted to find a framework in which they can place Gypsies, a group that most host countries regard as an anomaly. For example, Robert Redfield has described what he calls an idealized primitive

192. Indeed, a Romani source declares, perhaps facetiously, that people who are illiterate are better off and that an inevitable result of literacy is stupidity. LEE, AUTOBIOGRAPHY, supra note 29, at 27-28; see also Sally F. Moore, Treating Law as Knowledge: Telling Colonial Officers What To Say to Africans About Running "Their Own" Native Courts, 26 LAW \& SOC'Y REV. 11, 26-27 (1992) (stating that emphasis on literacy not always helpful when dealing with foreign cultures).

193. Jonathan H. TuRner, PATTERnS OF SOCIAL ORGANIZATION 216-18 (1972) (describing primitive legal systems); see also HOEBEL, supra note 19, at 114.

194. TURNER, supra note 193, at 216, 217-18 (scheme of courts in primitive legal systems).

195. OKELY, TRAVELLER, supra note 62 , at 28-29. 
or "folk society," which he contrasts with urban society. ${ }^{196}$ He conceives of the Roma as having retained many of the traits of his ideal folk society, in spite of their continuing migration throughout the world. ${ }^{197}$ He perceives the Roma as isolated, nonliterate, and homogeneous, motivated by a pervasive feeling of group identity-characteristics typical of a folk society. In addition, folk societies and Gypsies are governed by strict rules of convention that can be neither effectively challenged by individual members, nor controlled by outsiders. These conventions do not depend on discipline but are internalized among the members of the society, who conform to them in a consistent way and without much reflection. Consequently, there is no need for legislation. ${ }^{198}$ The members of Redfield's folk society act not as individuals, but spontaneously and uncritically according to tradition and as members of the clan. ${ }^{199}$ Religion and conceptions of status prevail in all phases of life. ${ }^{200}$

Redfield calls rules of convention or coherent patterns "culture,"201 although this Article would call them "law." The difference is not merely a matter of terminology. ${ }^{202}$ Reference to law as a cultural phenomenon strips it of centuries of meanings that are attached to the term "law." Although some detachment is gained by looking at law as a pattern, the change of terms demystifies law and alters its meaning in a negative fashion. In addition, reference to Gypsy laws as rules of convention and cultural patterns insulates them from comparison with the concepts of law that are traditionally employed in legal scholarship. Stressing that romaniya is law therefore is an important clarification of an historical distortion.

Many authors wrestle with the problem, also faced by this Article, that identifying commonalities among all Gypsies is difficult. The stress on literacy (which varies substantially among different Romani groups) seems to compound the problem. ${ }^{203}$ Illiteracy, according to Marlene Sway, is assumed to bar the Roma from entering any middle-class or professional occupations. On the other hand, the low-level positions available to them, such as factory work, conflict with the Gypsies' sense of dignity and need for autonomy. Illiteracy also prevents the cultural and intellectual values of the gaje from infiltrating and undermining traditional Gypsy society. ${ }^{204}$ Basic tenets of

196. Robert Redfield, The Folk Society, 52 AM. J. Soc. 293 (1947).

197. Id. at 296.

198. Id. at $299-300$

199. Id. at 301 .

200. Id. at 305 .

201. Id. at 299-300.

202. See supra note 189 and accompanying text.

203. See, e.g., SUTHERLAND, supra note 29, at 290-91; SwAY, supra note 52, at 124.

204. Id. Hancock, a noted linguist and Romanichal-Lovara Rom, in reviewing Sway's book, objects to her emphasis on illiteracy, and provides numerous examples of literate Romani professionals. Hancock, Review, supra note 35, at 73, 79-80. Hancock acknowledges, though, that the majority of Gypsies feel uneasy about schooling because Romani children are kept uncomfortably close to gajikane children for hours. Hancock, Gypsies, supra note 60, at 444. 
marime would begin to crumble with exposure. These conceptions of supposedly universal Gypsy illiteracy, combined with our own society's illiteracy of romani (Gypsy language) and ignorance of romaniya (Gypsy law), contribute to the difficulties experienced by gajikane legal authorities.

Some have compared Gypsies with other ethnic minority groups. But such comparisons may be confusing as they tend to oversimplify similarities and differences between groups. A correlation between the Gypsies and the Amish has been suggested. ${ }^{205}$ Both the Amish and the Roma are unusual minority groups because they have successfully separated themselves from the outside community. According to this view, the Amish are like the Roma in that they have their own rules of behavior, which in the case of the Amish are moral values and beliefs derived from the Bible. ${ }^{206}$ In Amish society, anyone who violates the rules may be shunned or even excommunicated. The shunned person may be asked to leave the community to prevent the stigma from tainting other family members. The punishment is not indefinite, and the wrongdoer can return to the fold after making prescribed amends. Likewise, the Amish have strict social boundaries isolating them from non-Amish, ${ }^{207}$ as well as clearly delineated rules for attire, language use, sexual roles and practices. Respecting elders and avoiding contact with outside institutions are two other similarities between the Amish and the Roma. ${ }^{208}$

While a comparison of the Roma with other ethnic groups is interesting, it can also be misleading. Apparently similar practices may serve entirely different functions and have completely separate histories. What appears to be a similarity may be coincidental. Comparisons here may also detract from the primary focus of attention, Gypsy law.

\section{Integration, Assimilation, and Adaptation}

The literature has contributed the concepts of integration, assimilation and adaptation which prove to be helpful terms when analyzing to what extent the

Among the Vlax Roma the conception of marime appears to be a critical factor in forming attitudes toward schooling and literacy. According to Vogel, the arrangements in public schools almost inevitably lead to pollution. Eating in lunchrooms, use of public bathrooms and shower facilities, integration of adolescent boys with girls, and programs of sex education are so problematic for some Gypsies that they prefer to keep their children out of school altogether. Vogel, supra note 29, at 37. For a Romani voice, see LEE, AUTOBIOGRAPHY, supra note 29, at 131 ("They were all too ready to give us . . their own brand of lobotomizing education, but they would never give us equality of culture."). $C f$. Grumet v. Board of Educ., 62 U.S.L.W. 2045, 1993 WL 241389 (N.Y. July 6, 1993) (New York school district established for Hasidic Jews).

205. SUTHERLAND, supra note 29, at 5-7. Sway compares Romani culture and Jewish culture. SwAY, supra note 52, at 47-48, 54-55; see also supra notes 47, 62,79,94-95, 98, 107, 111, 115, 206, and infra notes 286, 303 (references to Jewish tradition). But see Hancock, Review, supra note 35, at 75-76 (noting strained comparisons of Romani with Jewish culture).

206. SUTHERLAND, supra note 29 , at 6.

207. Id. at 5-6.

208. Id. at 6. 
Roma can be classified as an autonomous group. As the Article progresses, it will become increasingly apparent that true isolation is not possible, even for the Romani people. Autonomy and isolation are interrelated concepts. The degree of isolation determines the level of autonomy which a group can claim. Assimilation and integration undermine isolation and, therefore, group autonomy. Adaption, however, is a form of adjustment to the greater environment which preserves the inner character of an autonomous system.

Indeed, a key problem in understanding Romani culture in its relation to non-Romani cultures, including that of the United States, could be the distinction between assimilation and adaptation. The two concepts are not synonymous. Assimilation implies the demise of a distinct culture, or at least its merger into a dominant culture. Adaptation, on the other hand, implies the survival of a minority culture, despite conscious adjustments by its members to cope with a surrounding environment that is different and often hostile. Assimilation and adaptation are not necessarily exclusive of each other in practice, although conceptually they seem to be. ${ }^{209}$ Hancock's observation that gradual integration may lead in time to assimilation acknowledges this possibility.

Although the anthropological literature does not provide distinct legal analysis, it does explore the concepts of integration, assimilation and adaptation in a form that could prove to be useful for legal scholars. Sutherland suggests that the success of a minority group's integration into American culture can be measured by the degree to which members identify themselves as American and the degree to which they participate in a main aspect of social structure. ${ }^{210}$ She finds that Gypsies are less integrated into and identified with American society than are other ethnic groups. ${ }^{211}$

A Romani source confirms that Gypsies do not identify with American society. Accordingly, most Gypsies born in the United States refer to Americans as though they themselves were not included in this group and perceive American values as conflicting with their own beliefs. ${ }^{212}$ Sutherland adds that although the Gypsies have largely adapted to living surrounded by a foreign culture, their social organization fosters the separation of Gypsy from non-Gypsy. This separation places Gypsies at a greater disadvantage than other, less separatist ethnic groups. For example, African Americans and Latinos have suffered from discrimination in a number of areas, such as the educational system, but the Roma have tended to stay apart by choice.

209. Lee speaks of "incognito Gypsies," Roma who have adapted enough to pass as gaje, but are in danger of losing their identity. LEE, AuTOBIOGRAPHY, supra note 29, at 82-83, 116.

210. Id. at 290.

211. Id.

212. Hancock, Diaspora II, supra note 59, at 651. According to Hancock, this is even true of most fourth- and fifth-generation American-born Gypsies. Hancock stresses that Gypsies have for centuries adapted to their host cultures. See infra notes 214-16 and accompanying text. 
Although illiteracy (according to gajikane standards) may help the Roma preserve their ethnic identity by isolating them, it also handicaps them in the modern bureaucratic state. ${ }^{213}$ Yet according to Hancock, many Roma are slowly integrating and participating in the mainstream of American culture without compromising their identity. ${ }^{214} \mathrm{He}$ concedes that over time integration could lead to assimilation. ${ }^{215}$

It has been increasingly difficult for Gypsies to maintain a separate cultural identity, especially with the advent of mass media. Television follows them even if they migrate. Perhaps the closely knit Romani family and the presence of older women provide some measure of immunity to these "foreign" influences. These traditional Gypsies may accept television programs as no more than entertainment. If children watch the programs with adults, the latter are bound to comment on what is shown according to traditional Gypsy values. Furthermore, to the extent that television signals a shift from writing and print toward oral communication, it may move American culture closer to the oral traditions which have been longstanding features of Gypsy culture.

Although Gypsies have inevitably been exposed to popular culture as much as any other ethnic groups, their reactions have differed from those who more closely identify themselves as American. Indeed, minority status, civil rights, and integration are terms that do not necessarily have the same meaning for the Romani people as for African Americans, Latinos and Native Americans. ${ }^{216}$ In the case of the Gypsies, centuries of often vicious persecution seem to have strengthened the insularity of the culture, counteracting influences toward assimilation. As Sutherland observes, Gypsies have participated less in American social processes than have other minority groups. ${ }^{217}$ They have

213. SUTHERLAND, supra note 29 , at $290-91$.

214. Hancock, Diaspora II, supra note 59, at 651-52. Silverman, too, notes that American Gypsies have successfully adapted to their environment without losing their identity. In her view, the appearance of assimilation may actually be a cover that hides a robust Romani culture from the non-Gypsy world. Gypsies may encourage and exaggerate gajikane stereotypes about themselves, thereby concealing their culture. Silverman, Gypsiness, supra note 72, at 266. Quoting Jan Yoors, she somewhat facetiously suggests that the large volume of college-educated people in the United States "prepares them for psychoanalysis-and for fortune telling." Id. at 270 . Gypsies have also been adept at using modern technology to support their culture. Telephones, for example, are extensively used by Gypsies for communication with other Roma, for news about business opportunities, and for lucrative fortune-telling. The telephone encourages the orality of Romani culture. Id. at 271 . Silverman gives numerous other illustrations of how "Gypsiness" has been used innovatively to adapt to an American setting. In an earlier article she maintained that close proximity to non-Gypsies and economic dependence on them forces Gypsies to adapt as a means of survival. Silverman, Impression Management, supra note 180.

215. HANCOCK, PARIAH SYNDROME, supra note 1, at 130.

216. On some possible disadvantages of adaptation, especially if it results in greater visibility to American-style bureaucracies, see SUTHERLAND, supra note 29, at 290-91. In contrast, Hancock views adaptation positively. He maintains that throughout their history Gypsies have adapted successfully to their environment without assimilation. Trading with horses, for example, shifted to trading with cars. Similar changes among non-Gypsies, he notes, would be called progress. Hancock cautions that reasoning against adaptation might "keep Roma in a time capsule, or in a compound as a protected species!" Hancock, Letter, supra note 151 , at $8 \mathrm{nn} .100$ \& 102 .

217. SUTHERLAND, supra note 29 , at $290-91$. 
little inclination to contribute actively to the politics of non-Gypsies. African Americans and Latinos on the other hand have sought to increase their participation in American society, turning to highly visible civil rights litigation when their efforts have been rebuffed. If the Romani people move down the road of adaptation to American culture, it is likely that they too will bring increased demands for civil rights under the host legal system.

The operative and autonomous legal system governing Gypsy society has played a central role in promoting the astounding survival and integrity of Gypsy culture. Indeed, it is that law-related aspect of the problem that makes a study of Gypsy law, existing in our midst unnoticed, so vitally interesting. A close examination of the Gypsies' autonomous legal system sheds new light on aspects of American private lawmaking that have been overlooked.

\section{Central Features of Gypsy LaW and OtHeR Forms of PRIVATE LAWMAKING}

All forms of private lawmaking share certain basic features. Some of these features have parallels in state-made law and some do not. This Part first describes the centrality of the oral tradition to private lawmaking, discussing the natural progression of private lawmaking, from the memorization, storage, and retrieval of rules to their eventual expression and qualification. The oral character of private law is closely intertwined with the types of procedures the Gypsies have adopted. These procedures reinforce the importance of oral advocacy, thus encouraging the use of allusion. This Part next turns to the evidentiary rules of the Gypsies and draws lessons about our own legal system. Whether they are all-inclusive or exclusionary, rules of evidence have a critical effect on the outcome of legal controversies. Such rules determine whether only a narrow issue of dispute has been settled or whether a more searching inquiry into the roots of controversy will be undertaken.

\section{A. Oral Legal Tradition}

Reliance on orally transmitted tradition characterizes Gypsy law as well as other forms of private lawmaking. ${ }^{218}$ This feature distinguishes private law from the laws of the state, which are contained in printed sources. Even the invocation of state law occurs mostly non-orally, for example, by filing a

218. See supra notes 19-27 and accompanying text. Laws that are based purely on oral tradition are customarily perceived to be of an inferior nature, are occasionally ridiculed, and are not considered worthy of study. Ehrlich traces this attitude to the sixteenth century in Europe, when judges became law-trained officials of the state and were no longer required to know unwritten law. According to Ehrlich, the demise of customary law was complete by the end of the eighteenth century. EHRLICH, supra note 5, at 15 . Since then, law based on oral tradition has been treated as a fact to be proven by the parties under stringent burdens-in other words, not as a matter of judicial notice. 
written complaint. While printed or written sources-such as charters and bylaws of corporations or contracts-exist in private lawmaking, most private law never reaches this level of articulation. Yet private law still regulates conduct effectively by creating informal and implicit understandings that determine behavior and result in sanctions if violated. ${ }^{219}$ There can be little doubt that Gypsy law and adjudication, as employed in the kris of the Vlax people, is effective. What factors account for this high degree of effectiveness of oral legal traditions? A comparison of oral and printed law may furnish clues.

\section{Legal Functions of Memory}

Private lawmaking relies largely on memory and, as a result, encourages development of the mental capacity to retain information. Knowledge of past private lawmaking, to the extent that it is based on oral traditions, is acquired casually and almost effortlessly. For instance, in the case of the Gypsies, law may be transmitted through stories told by women or men, ${ }^{220}$ through the relation of illustrative and entertaining gossip, and through personal observation. Similarly, when we describe someone as an "experienced lawyer," we acknowledge the wealth of legal knowledge that person has accumulated from sources other than written law. Much of this knowledge has been acquired over time by observation and by listening to stories told by colleagues. A person who comprehends only written law would be inadequately prepared to practice law.

219. Id. at 86 .

220. YOORS, GYPSIES, supra note 42 , at $142-47$. Yoors explains that two forms of storytelling are known among the Lovara. Swatura are colorful stories based on personal or group experiences. Paramitsha are fairy tales. The fairy tales differ among the various Romani groups, and are sometimes influenced by stories in the respective host country. An original Romani fairy tale, contained in a German collection, reflects various implicit rules of law. The devil, disguised as a young Romani man of unknown origin, courted a young Gypsy woman. He asked her father whether he would give her to him in marriage. The father replied that it would be all right with him, if it was agreeable to her. She expressed her willingness. Ultimately, the young couple departed under some pretext without being married. Arriving at the young man's tent, the woman soon discovered that her companion was the devil. She induced him to retum to her parents on a visit. While the devil was drunk in the parental tent, a priest was brought to the scene. The devil escaped a ceremony of consecration, but a week later the young woman died. ZIGEUNERMÄRCHEN 266-68, 381 n.55 (Walther Aichele \& Martin Block eds., 1962).

Keeping in mind that the "young woman" in the fairy tale may have been a child, see supra note 101 and accompanying text, the rules of law implied by the story are:

(1) A marriage should be a concern of the families involved, not of the individuals.

(2) One should not marry unknown outsiders because they may turn out to be evil.

(3) Young women should not impose their will on elders.

(4) Elders should exercise control over their offspring.

(5) The sanction for violation of the rules could be death.

For a general description of the relationship among folktales, lore, and law, see HAROLD D. LASSWELL \& MYRES S. MCDOUGAL, JuRISPRUDENCE FOR A FREE SOCIETY: STUdies IN LAW, SCIENCE AND POLICY 353-55, 406 (1992). 
The most important tenets of private law are experienced and absorbed into the individual's psyche and reservoir of knowledge. What Sigmund Freud has called the superego is largely an internalized reflection, as well as a continued source, of private lawmaking. ${ }^{221}$ Although oral legal traditions may restrict individual liberty, their coercive features are not necessarily perceived by the members of the society. Even if the society notices the coerciveness of these legal traditions, it tends to tolerate them because they present themselves in the popular mind as "the way things always were" and consequently are more readily accepted than the printed laws imposed by the state. ${ }^{222}$

Memory may also affect the ways in which laws are changed. In an oral system, the chiefs who are trusted for their wisdom and knowledge may influence law over time by the ways they remember it. For example, the chiefs may make imperceptible changes in those legal traditions that no longer serve useful functions or reflect notions of times long gone by. Just as Gypsies change law in this fashion, ${ }^{223}$ much unwritten institutional law is gradually altered by selective forgetting. Such changes are hardly noted because they come about through organic growth or evolution. If the new rules are formally articulated as changes, so that participants become fully conscious of the fact

221. A definition of the superego illustrates the relation between this concept and private lawmaking: "[a] Freudian term for that aspect of the psyche which has internalized parental and social prohibitions or ideals early in life and imposes them as a censor on the wishes of the ego ...." 17 OxFORD ENGLISH DICTIONARY 217 (2d ed. 1989). Although the relation to Gypsy law and other forms of private lawmaking is evident, the definition seems to be less applicable to state law, especially in its technical aspects. We are indebted to Nancy Scheper-Hughes, Department of Anthropology, University of California at Berkeley, for suggesting a relationship between private lawmaking and internalized standards of conscience.

222. VON SAVIGNY, supra note 6, at 24 ("In the earliest times to which authentic history extends, the law will be found to have already attained a fixed character, peculiar to the people, like their language, manners and constitution.... That which binds them into one whole is the common conviction of the people, the kindred consciousness of an inward necessity, excluding all notion of an accidental and arbitrary origin.").

223. GROPPER, supra note 79 , at $98-100$, mentions several ways in which romaniya (Gypsy law) changes: (1) Archaic laws such as the prohibition against living in urban apartment complexes are simply ignored. Older rules disallowed such living arrangements because of the belief that women on higher floors were a polluting presence; (2) Use of hospitals for childbirth modifies older and restrictive marime rules; (3) The conflicting precedents of kris trials are used for creative court arguments. As in our legal system, precedent thus becomes a safety valve that permits rapid legal change; (4) Extenuating circumstances are often invoked to adjust the law to the hardship of an individual case. One could look generally at law reform as a set of emerging competing norms that are slowly incorporated into the earlier traditional norms, sometimes replacing them. 
that changes are taking place, then those changes might be rejected. ${ }^{224}$ In this respect, articulation can become a conservative force preventing innovation.

A legal system that relies solely on collective memory might not require experts in the law, because such a regime is manageable enough to be essentially self-executing. Nevertheless, individuals who know the law, or even better, who conform to it, may receive favored treatment. Among the Gypsies, for example, an individual's stature may increase to the point that the person becomes a candidate for leadership positions, such as a judge in a kris. ${ }^{225}$

Finally, although oral law exists at all levels of lawmaking, it is most effective within smaller social units: a family, a clan, or an institutional group, such as a faculty, a board of directors, a committee or a court. ${ }^{226}$ Although each of these units may have unwritten understandings, uniformity among them is not guaranteed or even a goal, which in turn may encourage dispute.

224. Weyrauch observed a similar phenomenon in an experimental setting on the Berkeley campus. This experiment, financed by NASA, took place in the spring of 1965 and was primarily concerned with nutritional aspects of prolonged space exploration. Nine male volunteers, between twenty-one and thirty years of age, were confined under close observation for about three months. Weyrauch's task was to observe and catalog the law that the experimental group generated under strict confinement. The fundamental rules that evolved within the group included:

1. Rules are not to be articulated. In case of articulation they are to be discarded, regardless of whether such articulation was accidental or deliberate. If a substantial segment of the group has in fact talked about the rule, the necessary level of articulation is reached and its existence is acknowledged.

A rule that has become spurious by articulation and acknowledgment can be discarded by any form of behavior designed to destroy its effectiveness, for instance by deliberate disregard in a demonstrative fashion without the nomal group sanctions which otherwise would have been imposed.

2. The closer a rule comes to a taboo area, the less articulate it should be. Minor administrative matters may be articulated.

3. The stringency of a rule is determined by the level of its articulation. The more articulate it is, the less the necessity to follow it.

Weyrauch, Basic Law, supra note 6, at 59; see also WEYRAUCH, THE LAW OF A SMALL GROUP, supra note 6, at 40-41; Weyrauch, Law in Isolation, supra note 6, at 39,41-45.

Professor Funk has commented that the rule of "nonarticulation" seems to apply to law faculties: "We do certain things in fact, though we sometimes do not want to admit it. If someone identifies and articulates what we really do, the group may change its actions. Our prior rule of behavior has changed because we cannot face its articulation." GROUP DYNAMIC LAW, supra note 6, at 178.

225. GROPPER, supra note 79, at 82-84; Lee, Kris, supra note 51, at 25-26.

226. See supra notes $22-27$ and accompanying text. A collegial court, for example, would apply the formal laws governing its jurisdiction as well as the unwritten law that governs its members. In fact, the latter may be crucial to the ultimate outcome of a particular litigation. See, e.g., Murphy, supra note 24. For a popular account of the informal rules of the Supreme Court, see BOB WOODWARD \& SCOTT ARMSTRONG, THE BRETHREN: INSIDE THE SUPREME COURT (1979). Former Chief Justice Burger's complaints about the low "quality" of attorneys appearing before the Supreme Court may have included an objection to their ignorance about the unwritten rules and understandings of the Court. Id. at 379. A high-ranking German appellate judge expressed similar views:

A selected group of specialized attomeys who constantly argue cases before us are not likely to waste our time. They know what we justices want to hear, and they bring just that. The out-of-town attomeys have no experience before a court of last resort. They talk too much. WALTER O. WEYRAUCH, THE PERSONALITY OF LAWYERS 230 (1964) (footnote omitted). As in any other social setting, the Supreme Court may have factions, which develop their own legal systems. WoODWARD \& ARMSTRONG, supra, at 65-69 (describing conservative faction within Burger Court). The informal law of a faction may clash with the law of other factions and the law of the group as a whole. See supra note 99 (autonomous systems within autonomous systems). 
Fundamentally, oral systems do not address themselves to the needs of a mass society as such, even though they satisfy the needs of the smaller units that comprise a mass society. Rather, printed laws are better equipped to serve the needs of mass governance. ${ }^{227}$

\section{Oral and Printed Law Contrasted}

Law based on printed sources contrasts dramatically with oral legal traditions. Since voluminous libraries house most of the printed sources of law, these sources can only be retrieved through catalogues, indices, and computers. Inevitably, print discourages the use of memory. ${ }^{228}$ It also requires literacy in the traditional sense. This reliance on literacy in legal society partially explains why non-Gypsy cultures object to the alleged illiteracy of Gypsies. ${ }^{229}$ Since literacy assists in the control and governance of large masses, a person perceived to be illiterate is more suspect to the host authorities and consequently more vulnerable to persecution. ${ }^{230}$

Under a system of printed law, then, memorization of legal sources is practically impossible and is in fact discouraged. ${ }^{231}$ The ability to retain knowledge of law through memory, as in an oral legal culture, fades. Eventually the doctrine of constructive notice emerges; the content of printed law is deemed to be known by all. In other words, a legal fiction compensates for the growing inability to remember and is sufficient to hold people legally responsible despite their lack of knowledge or even their capacity to know. ${ }^{232}$

227. For example, contemporary tax collection, without a code or some other printed source, would be impossible.

228. The same is likely to be true of computers. See, e.g., Paul Schwartz, Data Processing and Government Administration: The Failure of the American Legal Response to the Computer, 43 HASTINGS L.J. 1321, 1355 (1992) (claiming that extensively trained professionals have been replaced by clerks who are only expected to process paper and operate machines); see also Moore, supra note 192, at 26-28 (describing conflict between oral tradition and record-keeping reform in colonial Africa).

229. See, e.g., MCLAUGHLIN, supra note 58, at 37 (stating that "most gypsies [in America] are illiterate or, at best, semiliterate"). But see Hancock, Review, supra note 35, at 73 (noting that among Vlax men literacy is not unusual; among Bashalde and Romanichal literacy is common). The persistent emphasis on Gypsy illiteracy, see supra note 204, reflects a disturbing hubris. According to a U.S. Department of Education report, based on a Princeton Educational Testing Service survey, nearly half of the American adult population has a low level of literacy-lower than that which a moderately demanding job would require. But when asked whether they read well or very well, $71 \%$ of those in the bottom fifth replied "yes." Paul Gray, Adding Up the Under-Skilled: A Survey Finds Nearly Half of U.S. Adults Lack the Literacy To Cope with Modern Life, TIME, Sept. 20, 1993, at 75.

230. People who are illiterate ordinarily cannot be naturalized as U.S. citizens. 8 U.S.C. $\$ 1423$ (1988).

231. See, e.g., EhrLICH, supra note 5, at 458 (referring to Georg F. Puchta's statement "As the law develops, the mass of legal material increases to such an extent, and the science of law becomes so refined that a comprehensive knowledge and a scientific mastery of the law can be found only among the jurists."). Although Ehrlich refers in this context to "juristic law" as a means of articulating customary law, one may assume that at this advanced stage of development, the sources of law can no longer be found in oral tradition, but rather exist in custom that has been reduced to writing. Id. at 450 .

232. For a discussion of fictions, see LON L. FULLER, LEGAL FICTIONS (1967); HANS VAIHINGER, THE PHILOSOPHY OF "As IF" (Charles K. Ogden trans., 2d ed. 1935); see also FRANK, supra note 15, app. VII at 338-50 (commenting on Vaihinger's book). 
Actual knowledge of printed sources of law promulgated by the state, to the extent that it is still required or needed for purposes of legal education, admission to the bar, or administration of justice, is acquired by a process of forced memorization. This compulsory process breeds resentment and results in a reduced ability to retain the learned information. ${ }^{233}$ It also creates a professional class of lawyers. ${ }^{234}$

The rules of law as represented in printed sources tend to become increasingly abstract. ${ }^{235}$ Concrete legal stories are no longer viewed as primary sources of law, although they have to some extent survived in common law systems that rely on case collection. The more compact and abstract the printed norms, the more they lend themselves to the development of theory - a feature that is not present in private lawmaking based on oral traditions. ${ }^{236}$ The capacity for abstract and theoretical thinking becomes a mark of intelligence, as distinguished from wisdom, in mass society. Tests develop to designate at an early phase potential candidates for key positions along these lines of merit. ${ }^{237}$

Printed law tends to be relatively static and is difficult to alter. Once law is reduced to print, one is often "stuck with it," unless an ambiguity can be found; even then change or adaptation requires special effort. The procedures for change are complex, especially in comparison to the ease with which oral law can be altered. ${ }^{238}$ Printed law can be changed by statutory amendment, by overruling precedent, or by reinterpreting existing law to accommodate new circumstances. Some of these methods of reform may employ subterfuge. ${ }^{239}$ Therefore, realizing these changes usually requires a conscious effort. ${ }^{240}$ Merely forgetting or employing a qualified oral account will not suffice.

233. See Paul T. Wangerin, Skills Training in "Legal Analysis": A Systematic Approach, 40 U. MIAMI L. REV. 409, 469 n.121 (1986) (noting that cramming can temporarily improve performance, but leads to decline of performance in long run).

234. TURNER, supra note 193, at $225-26$ (discussing how differentiation of law requires professionalized lawyers and judges).

235. On abstract rules, see POSPISIL, ANTHROPOLOGY OF LAW, supra note 6, at 20-37. The law of the Romani people and the private laws in our society do not depend on the abstract rules described by Pospisil. They rely on legal tradition as communicated by word of mouth and observation. These forms of autonomous lawmaking continue to exist contemporaneously, usually unnoticed, with abstract rules of the law of the state. See supra note 30 and accompanying text.

236. EHRLICH, supra note 5, at 348 (describing evolution of "juristic science").

237. Weyrauch, Governance, supra note 46, at 150-53; Developments in the Law-Equal Protection, 82 HARV. L. REV. 1065, 1166-67 (1969). For example, the notion that the capacity for abstract thinking (as opposed to other forms of intelligence) is at the core of American IQ tests has been developed in Arthur R. Jensen, How Much Can We Boost IQ and Scholastic Achievement?, 39 HARV. EDUC. REV. 1, 19 (1969). Jensen's article, perhaps inadvertently, exposes the cultural and ethnic biases in prevailing conceptions of intelligence. See supra note 46.

238. See supra note 223 and accompanying text (ease with which romaniya changes).

239. See, e.g., LLEWELLYN, supra note 14, at 70-76, 97-105; HENRY S. MAINE, ANCIENT LAW 23-32 (Henry Holt \& Co. 1906) (1861); HENRY S. MAINE, EARLY LAW AND CusToM 118-21 (London, John Murray 1891); Julius Stone, SOCIAL DIMENSIONS OF LAW AND JuSTICE 130-33 (1966).

240. This method of expressing law in a fashion that outwardly conforms to precedent but actually submits it in an altered form seems to be common in Romani legal proceedings and can also be observed in other gatherings that rely on oral tradition, such as committee and faculty meetings. 
Printed law of the state may also result in dead-letter law, namely, law that is no longer applied but continues to retain a nuisance value by being on the official books. Such dead laws may sometimes come to life in unpredictable ways. ${ }^{241}$ Furthermore, as outdated laws grow unfamiliar, the populace perceives their application to be oppressive and unfair.

The jurisprudential distinction between the law-in-books and the law-in-action suggests an emphasis on printed sources in legal systems which place value on written law. Yet, even where institutions of written legal history prevail, law-in-action may shape legal practice and thereby incorporate private lawmaking into the law of the state. ${ }^{242}$ Accordingly, the dichotomy between oral legal traditions and the written law of the state is not absolute. The actual outcomes of cases tend to be influenced by norms of unwritten law which are never fully articulated. These unwritten norms may prevail in clashes with the traditional printed sources of law because such norms have greater persuasiveness. ${ }^{243}$

This analysis demonstrates that, while there are fundamental differences between legal systems exclusively based on oral tradition, such as Gypsy law, and those based on written tradition, the law of the state is based much less on written law than is commonly assumed. In fact, the law of the state could not survive without the continued influence of orally transmitted legal traditions.

241. POSPISIL, ANTHROPOLOGY OF LAW, supra note 6, at 26-27. For a discussion of dead laws and how they may be reinstituted, see Robert C. Berry, Spirits of the Past-Coping with Old Laws, 19 U. FLA. L. REV. 24 (1966). Mashburn points out that seemingly dead rules are dangerous because they lend themselves to unpredictable and selective enforcement. Amy R. Mashburn, Pragmatism and Paradox: Reinhold Niebuhr's Critical Social Ethic and the Regulation of Lawyers, 6 GEO. J. LEGAL ETHICS 737, 783-84 (1993). As illustration, she refers to MODEL RULES OF PROFESSIONAL CONDUCT Rule 8.3 (1983), according to which attomeys must report the misconduct of other attomeys. This rule is essentially unenforced, but in one controversial case, an Illinois attomey was suspended from practice for violating the rule. In re Himmel, 533 N.E.2d 790 (Ill. 1988); Ronald D. Rotunda, The Lawyer's Duty To Report Another Lawyer's Unethical Violations in the Wake of Himmel, 1988 U. ILL. L. REV. 977.

242. Pound, supra note 18 , at 19.

243. This statement may apply more to legal processes in the United States than in civil law countries that rely on essentially written procedures in the courts. See, e.g., Richard C. Maxwell \& Marvin G. Goldman, Mexican Legal Education, 16 J. LEGAL EDUC. 155, 170 n.62 (1963) (noting anomaly that Mexican lawyers, after passing oral examinations, apply written procedures in court, while American lawyers pass written tests and then use oral advocacy before judge and jury). American law relies heavily on oral skills and thereby facilitates the influx of notions based on oral tradition. In divorce cases, for example, written law may grant husband and wife equal rights to the custody of their children. In spite of this, it is difficult for a divorced husband to obtain custody of his twelve-year-old daughter. There is an unarticulated cultural norm, no matter how factually inaccurate, that a single adult male cannot be trusted in an intimate living arrangement with a young female. It would be impossible, however, to articulate this highly prejudicial concern openly in court. Lawyers instead prefer veiled references to sexual concerns by arguing that the daughter is "maturing" and needs the guidance of the mother in "hygienic matters." See, e.g., Boroff v. Boroff, 250 N.W.2d 613, 617-18 (Neb. 1977) (noting that although Nebraska law provides both parents with legal right to custody of their children and twelve-year-old girl expressed preference to live with her father, trial court improperly awarded custody to mother until twelve-year-old "gets through maturity"). On the dominance of unwritten and often prejudicial private law in child custody matters, see supra note 17 and accompanying text.

Mashburn offers another illustration demonstrating how unwritten private law prevails over written law. Experience demonstrates that the informal private law among lawyers prevails over the official and written mandate to report on each other. Mashburn, supra note 241, at 783-84, 788. 
Yet this influence often goes unnoticed, and the nature of law is increasingly viewed by legal scholars in terms of the written law of the state. Consequently, misunderstandings permeate every phase of law and affect legislation, judicial processes, the practice of law, and legal education. Perhaps the most significant impact of these misunderstandings can be seen in popular misconceptions of law. Law is often viewed as an oppressive force that runs counter to what is truly sound and just, but the popular conception of law usually is based only on the law of the state and those who apply it. It fails to include a broader understanding of law that also considers the effects of private lawmaking. Accordingly, those who are dissatisfied with law may not realize that some of the more oppressive elements of the law may stem from the spheres of private lawmaking.

\section{B. Procedure and Substance}

Unlike state law, private lawmaking does not draw a strict distinction between procedural and substantive rules. In systems of law that are based on oral tradition, procedure and substance do not serve identifiably discrete functions. ${ }^{244}$ Nevertheless, some of the rules of oral legal systems might be described as more procedural than substantive in nature. For example, Gypsy law emphasizes that grievances are not to be resolved by violence; rather, certain procedures must be followed to obtain redress. In the case of the Vlax, a divano has to be called, possibly followed by a kris. These procedures require the resolution of several issues: who may serve as a judge (krisnitori); who may present evidence as a witness; who may be present at the proceedings; and what language will be used in the proceedings. Language, in particular, has consequences for substantive legal issues as well as procedural ones.

\section{Role of Language}

One may view language, which shares certain characteristics with law in general, as a form of private lawmaking. For example, language is shaped by strict rules that may result in sanctions when violations occur. ${ }^{245}$ Inappropriate or casual usage at the wrong occasion (for example, in a formal setting or examination) can permanently mar the offender's social status and

244. Though our legal system has highly sophisticated and distinct roles for procedural and substantive rules, it is important to note that decisions based on procedure often mask substantive results. Stanley Ingber, Procedure, Ceremony and Rhetoric: The Minimization of Ideological Conflict in Deviance Control, 56 B.U. L. REV. 266, 270-73 (1976); Walter O. Weyrauch, Law as Mask-Legal Ritual and Relevance, 66 CAL. L. REV. 699, 714-26 (1978) [hereinafter Weyrauch, Law as Mask].

245. See, e.g., Jones v. Hallahan, 501 S.W.2d 588 (Ky. Ct. App. 1973) (holding that same-sex partners are incapable of entering into marriage because dictionary definition of the word "marriage" requires union of male and female). 
professional career. In a Vlax kris only Romani may be spoken; those who inadvertently switch to English are shouted down and may lose some social esteem in the eyes of their peers. ${ }^{246}$ Those speaking in a kris use a special oratory, comparable to the elocution of lawyers or politicians, which differs in grammar and content from ordinary speech. A Gypsy who masters this oratory gains respect and may be selected as a chief or krisnitori. ${ }^{247}$

Proper use of language, especially the skillful use of nuance and connotation, may be one vehicle for private lawmaking. Because legal allusions, implications, and inferences tend to be more effective than articulated rules, ${ }^{248}$ it may be more important for a non-Gypsy lawyer to know what can be inferred from the law, rather than to know what the law actually says. Interpretations of rules reach matters that are not fully articulated in the rules themselves. Thus interpretation becomes a method by which private lawmaking and the printed rules of the state are fused. ${ }^{249}$ Most private lawmaking has low visibility, but the rules governing construction, interpretation, implication, and inference in relation to state laws are of major significance, even though they must be applied differently in each set of circumstances if they are to be effective.

Because language remains unrecognized as a form of private lawmaking, it is often unevenly applied, leading to seemingly inconsistent results. For instance, in litigation under the laws of the state, a party may lose because of the blunders of counsel who communicated the wrong inferences at the wrong time or who relied on a technically correct legal argument, without realizing that the argument also conveyed negative implications. ${ }^{250}$ Language thus

246. Hancock, Letter, supra note 151, at 4 n.44; Lee, Kris, supra note 51 , at 28.

247. See supra note 144 and accompanying text; see also GrOPPER, supra note 79 , at 84-85.

248. See supra note 243 and accompanying text.

249. See, e.g., United States v. Universal C.I.T. Credit Corp., 344 U.S. 218, 221 (1952) (Frankfurter, J.) ("Generalities about statutory construction help us little. They are not rules of law but merely axioms of experience."). Justice Holmes made the same point in Boston Sand \& Gravel Co. v. United States, 278 U.S. 41, 48 (1928); see also FRANK E. COOPER, LIVING THE LAW 71 (1958) ("The law in action is principally concerned with problems of statutory interpretation and application."); GRAY, supra note 7, at 125 ("Nay, whoever hath an absolute authority to interpret any written or spoken laws, it is he who is truly the Law-giver to all intents and purposes, and not the person who first wrote or spoke them.") (quoting Benjamin Hoadly, Bishop of Bangor, from his sermon preached before the King in 1717). These authorities lend support to the proposition that interpretation may be a surreptitious means by which private lawmaking tends to prevail over written law. The "axioms of experience" referred to by Justices Frankfurter and Holmes, then, are really incidents of unrecognized private lawmaking.

250. Any lawyer can attest to numerous experiences of this kind, both on the trial and appellate level. The problem may also exist in other contexts such as negotiation. In spite of their negative impact, these occurrences ordinarily go unrecorded. Furthermore, lawyers do not view them as violations of oral legal traditions, but as inadvertent slips or as the result of incompetence.

Gossip is one of the main enforcement mechanisms of private lawmaking in romaniya, as well as within a law firm or university faculty. SUTHERLAND, supra note 29 , at 100 (noting gossip as major form of social control among the Roma). The absence of due process in gossip is self-evident. Yet, gossip is a double-edged sword. It may result in severe sanctions if used unjustifiably. Tillhagen, III, supra note 130, at 29-30 (referring to kris sentences against gossiping women among Swedish Roma). 
affects the application of both private and state law and brings about results that may be hard to remedy.

The reasons for the lack of procedural remedies may be different, though, in private and state law. In private lawmaking, certainly in the case of Gypsy law, language and law are indistinguishable, and the ultimate outcome of a controversy must be accepted. In proceedings under state law, language is not recognized as falling under the traditional definitions of law, although it obviously affects outcomes. A damaging implication, even though inadvertent, creates problems on appeal, partly because the record may not reflect it and partly because the parties, viewed as having had their day in court, are held responsible for any avoidable mishaps. Realistically, language must be recognized as a form of private lawmaking that is necessary for the state law system.

\section{Role of Legal Strategy}

The misguided notion that substantive law promulgated by the state can uniformly and mechanically resolve disputes relegates procedural strategy to a secondary and disparaged status. Similarly, emphasizing theory over practice often neglects the role of strategy in the application of law. ${ }^{251}$ Strategy incorporates private lawmaking into the process of adjudication. Because strategy plays a role in the resolution of legal disputes the more skillful advocate is likely to prevail, regardless of what the law of the state may ordain.

An essential element of strategy is the exploitation of the preconceptions of the people who are addressed, whether they are part of a court or some other decisionmaking body. If this were done directly, it would probably be resented or considered insulting. If, however, the advocacy remains at the level of innuendo, it confirms the preconceptions of the addressee and thus establishes sympathy for the advocate and the cause. The persuasive power of innuendo in legal argumentation may have its source in private lawmaking. The innuendos imply that the lawyer who makes them is "in the know." There is no need for the advocate to be direct because the participants are assumed to be knowledgeable anyway. Furthermore, articulation of the lawyer's reliance on private lawmaking might paradoxically result in the judge's or jury's decision to refuse to consider the informal rule. ${ }^{252}$ The advocate's implications tend to relate to informal processes that, rather than being based on state law, reflect what law "actually means." Whether the inferences in fact do so is a matter of conjecture, but this approach tends to be persuasive. One

251. See, e.g., 1 ANN F. GINGER, JURY SELECTION IN CIVIL \& CRIMINAL TRIALS at ix-x (2d ed. 1984) (discussing uneasy relationship between legal theory and practice in United States).

252. See supra note 224. 
could ask whether such strategies merely appeal to power relationships. But it is more accurate to assume that when such strategies are employed, private lawmaking (premised on communal authority as a higher form of law) is invoked.

Consequently, private lawmaking, although often neglected by legal theory and administration, actually plays a critical role in determining legal outcomes. One might argue that legal strategy, as well as emphasis on forms of private lawmaking, could detract from or damage law by propagating skills that are devious or unethical, such as winning a controversy by creating innuendos that are hard to refute and impossible to review. A response to this objection is that these strategies permeate law at all levels and cannot be eliminated. Furthermore, these strategies should be considered a generally beneficial intersection between public law and norms that are widely held, but unacknowledged because they are products of private lawmaking.

Lynn LoPucki has expressed a related thought: because legal strategies have determined the outcome of cases, without regard to the cases' merits, many people have concluded that the development of legal strategies is unethical, regardless of whether the "rules of the legal game" were observed. In such instances the superior strategists would be better manipulators of the system, not better thinkers. ${ }^{253}$ LoPucki counters that the development and publication of legal strategies is highly ethical. Exposing contradictions between legal theory and practice encourages and facilitates law reform. It would be unfortunate, LoPucki concludes, if those who expose the need for reform face the stigma of being labeled "unethical."254

253. LyNN M. LOPUCKI, STRATEgIES FOR CREDITORS IN BANKRUPTCY PROCEEdiNGS at xxix (1st ed. $1985)$.

254. Id. at xxx; see also ROBERT E. KeETON, TRIAL TACTICS AND METHODS at $x$-xi (2d ed. 1973) (observing that candid discussion increases appreciation and understanding of danger).

For an illustration of the crucial impact of strategy on litigation, see the closing argument of Pennzoil's lead trial counsel in Texaco, Inc. v. Pennzoil Co., 729 S.W.2d 768 (Tex. Ct. App. 1987), cert. dismissed, 485 U.S. 994 (1988), resulting in a verdict in excess of $\$ 11$ billion against Texaco:

You people here, you jury, are the conscience, not only of this community now in this hour, but of this country. What you decide is going to set the standard of morality in business in America for years to come.

Now, you can turn your back on Pennzoil and say, "Okay, that's fine, we like that kind of deal. That's slick stuff. Go on out and do this kind of thing. Take the company, fire the employees, loot the pension fund. You can do a deal that's already been done."

That's not going to happen.

I have got a chance. Me. Juror.

I can stop this. And I am going to stop it. And you might pull this on somebody else, but you are not going to run it through me and tell me to wash it for you.

....

You can send a message to corporate America, the business world. Because it's just people who make up those things. It isn't as though we are numbers and robots. We are people. And you can tell them that "you are not going to get away with this."

I ask you to remember that you are in a once-in-a-lifetime situation. It won't happen again. It just won't happen. You have a chance to right a wrong, a grievous wrong, a serious wrong. 
Yet what LoPucki calls the "merits" of a case is an elusive concept that often cannot be determined with any degree of certainty. Such a determination, elusive as it is, comes primarily from the laws of the state rather than private law. Indeed, the strategies or rules of the legal game to which LoPucki refers are in fact an application of private lawmaking to the process of adjudication. But law reform is exclusively focused on the formal laws of the state. Law reform in that limited sense is not likely to reach private lawmaking, which, like Gypsy law, is shielded by its invisibility. But the invisible forms of private lawmaking around us are governed by identifiable patterns that can be observed and learned. To that extent, perhaps private lawmaking can be regulated somewhat. At a minimum, legal theory would no longer limit itself to analysis of an essentially closed system of law, but would become more comprehensive by acknowledging that competing private legal systems exist.

Strategy plays a role in the kris of the Vlax, although the Gypsies may not be conscious of a dichotomy between strategy and the merits of a case. The Gypsies use what might be called strategy in the preliminary phase of the proceedings, attempting to use the selection of the krisnitorya to influence the outcome. This strategy is, however, of limited effectiveness; both prospective litigants must agree on the choice of judge and voluntarily consent to abide by the decision of the kris. If one party attempts to use strategy too forcefully, the other party may refuse to cooperate. ${ }^{255}$ During the trial, the parties or their chosen representatives attempt to influence the resolution of the controversy by skillfully presenting the case, resorting to precedent and even folklore..$^{256}$ These maneuverings are not, however, fully "strategy" in the gajikano sense of the word, for Gypsies believe that supernatural powers, not tactics, decide the merits of a case. ${ }^{257}$ Gypsy law traditionally places great emphasis on the oath in the examination of the parties and of witnesses, a practice that might be compared to elements in our own law with an historical origin, such as the ordeal and adversarial advocacy. ${ }^{258}$

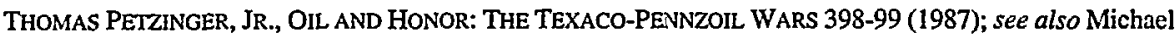
Ansaldi, Texaco, Pennzoil and the Revolt of the Masses: A Contracts Postmortem, 27 HOUS. L. REV. 733, 836 n.396 (1990). Earlier, Pennzoil had succeeded in removing the case from the Delaware courts, which are known for their expertise in corporate law, to Texas, for a trial by jury. Id. at $835 \&$ n.394. The emphasis thus shifted from application of the law of the state to private lawmaking.

255. See, e.g., GROPPER, supra note 79, at 81-82; Lee, Kris, supra note 51, at 26, 29.

256. GROPPER, supra note 79, at 83-85; Lee, Kris, supra note 51, at 29; Nemeth, Field Notes, supra note 128 , at $128-33$.

257. Jeatran, Social Control, supra note 139, at 25 ("The kris has a sacred aspect which is absent in American courts. The concept of marime is an important part of Gypsy religious thought, and its presence in the kris tends to blur the distinction between crime and sin. One observer has likened the kris to a religious cleansing, much like the (Roman Catholic) sacrament of confession."); see also Hancock, World Citizens, supra note 170 (manuscript at 5) (describing Romani belief in kintála, a state of spiritual "balance" that includes strict adherence to Gypsy law).

258. See, e.g., Helen Silving, The Oath: I, 68 YALE L.J. 1329 (1959); Helen Silving, The Oath: II, 68 YALE L.J. 1527 (1959). Descriptions of the oath in Romani procedures (Gypsy law) can be found in YOORS, GYPSIES, supra note 42, at 177-79; Lee, Kris, supra note 51, at 28-29; Tillhagen, III, supra note 130, at 21-24. On the ordeals, wager of law, and trial by battle, see THEODORE F.T. PLUCKNETT, A 
In the Anglo-American tradition, calling upon God as a witness while falsely swearing an oath was assumed to bring about the wrath of divine powers, regardless of whether the perjury was ever discovered. Similarly, the ancient ordeals (e.g., gripping a heated iron without serious consequence) invoked the powers of divinity to furnish proof of a witness' veracity. Some of these notions have survived in contemporary proceedings under state law. The oath is still available as a method of evidence. Declining fear of divine punishment, however, has weakened the oath as a legal institution-witness the modern state's need to impose worldly penalties on perjurers. The notion has also survived that, in a competitive contest between two attorneys in the examination and cross-examination of witnesses, the truth emerges. Irreversible negative consequences of minor flaws in strategy, committed not by the parties but by their legal representatives, are considered justified and sometimes even hailed as indications that the winner had a better case. Indeed, although declining fear of divine punishment has weakened the significance of the oath in our own law, the oath persists as a mode of evidence. Such practices, common to both Gypsy law and contemporary law of the state, attest to the underlying belief that powers beyond human control favor the person who is right. To the extent that the authority of the kris stems from a belief in divine powers, a dichotomy between strategy and merits is not really possible. The Gypsies perceive the outcome to be determined on a plane that is beyond the reach of human manipulation, and even strategy is viewed as a manifestation of a higher will.

\section{Role of Substance}

There is no clear demarcation between procedure and substance in Gypsy law. ${ }^{259}$ Similarly, those aspects of Gypsy law that can be viewed as essentially substantive in nature cannot be subdivided into criminal law, civil law, or other branches of law. There is no need for such distinctions because Gypsy dispute resolution dispenses corrective measures against socially inappropriate or deviant behavior regardless of whether such behavior would be criminal or civil under our classification scheme; Gypsy law uniformly applies the same standards of evidence and methods of proof, without concern

CONCISE HISTORY OF THE COMMON LAW 113-19 (5th ed. 1956). Similar to the old English ordeal of the "cursed morsel," id. at 114, Gypsy law provided for a form of ordeal, at least in Europe. In the Gypsy ceremony, a substance would be given to the plaintiff and defendant to swallow; the party who became ill would be assumed to be at fault. See GROPPER, supra note 79, at 97. For a comparison of lie detector tests, oaths, and ordeals, see $i d$.

259. The Romani word kris reflects the various aspects of Gypsy law combining procedure and substance. It has been defined by Gropper as "justice" or "court trial." GROPPER, supra note 79, at 205. Gropper writes: "This concept is central to Gypsy culture and refers to a whole complex of ideas and behavior patterns, including the whole body of customary law, the procedures of holding a court trial, and the underlying world view and value system." Id. 
for the type of case. ${ }^{260}$ By contrast, in the law of the state, the standards of evidence and proof, as well as sanctions, differ in civil and criminal proceedings because of the social opprobrium that attaches to criminal but not civil violations. This differentiation is more appropriate in non-Gypsy society, which is not as cohesive as Romani society (although divisions exist there, too). Treating all segments of the non-Gypsy society according to such a uniform standard for all infractions is not possible in a culturally diverse society.

These differences are reflected in the differing roles of substantive law. Gypsy law's emphasis on states of purity or pollution seems removed from our perceptions of the nature and function of law. The treatment of women and sexual matters by Gypsy law appears irrational and antiquated by non-Gypsy standards. But this apparent irrationality may be a clue to the effectiveness of Gypsy law. Under these orally transmitted rules, a whole culture has succeeded in protecting itself from the pervasive influences of host countries.

Reference to matters of an intimate and sexual nature may have a mnemonic function that should not be underestimated. In an oral legal tradition, rules must be preserved in a form that allows for easy recall, such as stories. ${ }^{261}$ Such stories must have a content that catches the attention of the audience. Any rule that incorporates intimate matters directly or indirectly related to procreation will more likely be remembered and observed because it is concerned with the survival of the species. The rigidity of such rules and their apparent absurdity to the contemporary non-Gypsy observer erect protective hurdles against interaction with persons belonging to the surrounding cultures. This separation results in an assertively endogamous society in which the women have a special role in safeguarding cultural identity through the enforcement of substantive rules of law. ${ }^{262}$ Indeed, law of this type plays a

260. Cf. supra note 244 and accompanying text; see also HOLLEMAN, supra note 20, at 5-9. According to Holleman, the main function of tribal procedure is to maximize rather than to restrict the scope of substantive inquiry. Although Holleman discusses tribal law within African cultures, much of his argument is applicable to romaniya (Gypsy law). It is also applicable to informal adjudication of private lawmaking in western societies, as it occurs in institutional settings. Illustrations include ways in which it is traditionally decided whether an associate in a law firm should be made partner; whether in a university faculty a candidate should be granted promotion or tenure; whether and to what extent salary increases should be given; whether disciplinary measures should be initiated; and in what form they should be imposed. On the Clarence Thomas confirmation hearings' resemblance to a tribal adjudication, see supra note 23.

261. Such was the function of rhymes, assonance, and alliteration in early epic poems and sagas handed down orally at a time when print was not available. See, e.g., Charles Collier, Origins and Development of Medieval European Epic: The Problem of Cultural Transmission and Transformation, 9 MEDIAEVALIA 45 (1983). On the role of story, myth, and magic in the oral tradition of the Romani people, see CLÉBERT, supra note 44, at 161-90; see also Rade Uhlik, Serbo-Bosnian Gypsy Folk-Tales, 38 J. GYPSY LORE SOC'Y 134 (B. Gilliat-Smith ed. \& trans., 1959).

262. See supra notes 80-108 and accompanying text. Subordination of Gypsy women to men has been stressed in the literature, see Okely, Gypsy Women, supra note 62, at 58-60. Yet, "Marime is what a woman has-that's her power." Miller, Thesis, supra note 63, at 40 (quotation from Romani source). One aspect of this apparent subordination is that women have become central figures in Romani culture. It is conceivable that the concept of gender subordination derives from contemporary gajikano culture (our 
critical role in these respects because it cements the cultural unity of the people.

This role for law appears at first glance to be unique to the Gypsy culture, but there are parallels in the American legal system. Although American law presents itself as neutral, it still functions to cement the cultural unity of the people. As in Gypsy law, many elements of United States law represent aspirational norms that are rarely fully realized, but instead hold out a promise. ${ }^{263}$ Since there is commonality of neither ethnic origin nor religion in the United States, law assumes a major role in expressing common hopes: the equality of all people, for example. To the extent that the law of the state relies openly on aspirational fiction, it issues demands that are justified on the basis of facts and reasoning which do not correspond to reality. Some rules of law that have been attacked for generations because of their apparent irrationality have shown an uncanny capacity to survive and persuade when argued in court. ${ }^{264}$

The parallels between Gypsy lawmaking and private lawmaking are even more apparent. Institutional ritual, especially if it appears to be irrational, can often have great staying power. Sometimes it is frozen in articulated form, such as Robert's Rules of Order or the various collections relating to social etiquette. ${ }^{265}$ The apparent irrationality in institutional rituals may actually enhance institutional cohesion and continuity. The willingness of participants to submit themselves to the government of these private rules, especially if they are tedious, may attest to institutional loyalty. If some members attempt to deviate from the rituals, they become known as persons on whom one cannot rely, and are prevented from assuming significant responsibility. Whether their protests are justified under the traditional law of the state is not the issue. The determinative factor is whether objecting members violate the mandates of unwritten private law, a reason why private law tends to prevail when it collides with laws of the state.

society) and provides little understanding of the status of women among Romani people. Their status is likely to be greater than perceived from the outside. See also CLÉBERT, supra note 44, at 140-41 (noting propensity of Gypsies to have cults of the female). Perhaps these factors should be considered in determining whether the treatment of Gypsy women violates international human rights standards. See Reisman, Comment, supra note 46 , at 416.

263. FULLER, MORALITY, supra note 11, at 41-44 (aspirations of law), 104 (aspirations of constitutional law); see also supra note 12 (referring to theories of Grey).

264. Among such rules are the statute of frauds and the parol evidence rule. See, e.g., 2 ARTHUR L. CORBIN, CORBIN ON CONTRACTS $\$ 275$, at 14 (1950) (noting statute of frauds promotes "illusion of certainty"); $3 \mathrm{id}$. 573 , at 370 (1960) (noting parol evidence rule "presents many problems" in "its practical application"). With regard to procedure, see FREDERIC W. MAITLAND, EQUITY, ALSO, THE FORMS OF ACTION AT COMMON LAW-TWO COURSES OF LECTURES 296 (1929) (common law forms of action rule us from their graves).

265. HENRY M. ROBERT, ROBERT's RULES OF ORDER (Sarah C. Robert ed., 1990); see also, e.g.,

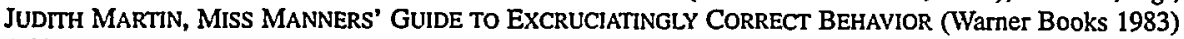
(1982). 
The sanctions imposed on a person who has violated an unwritten code within an institution or business often cannot be ameliorated through the remedies available under the laws of the state. ${ }^{266}$ The whistleblower, for example, may conform to a moral and legal duty to inform, but such an act invariably violates the unwritten internal law not to inform. ${ }^{267}$ Even if the whistleblower.wins in court and receives damages for wrongful discharge or reinstatement, he or she will not likely survive as a member of the group whose unwritten code has been breached. Similarly, a legislatively required loyalty oath may be constitutionally flawed. Yet if governmental employees raise this issue and withhold their signatures, they may find themselves unemployed, and even if they win in court they will rarely in fact be reinstated. More likely they will settle and voluntarily go elsewhere. In other words, the unwritten group norm which demands punishment for an employee who is disloyal to the group is likely to prevail over any remedy mandated by the state. ${ }^{268}$

The illustration of the discharged government employee can be generalized. A legal provision that is void or questionable under the law of the state, if operative within an institutional context, can serve to identify those willing to raise a legal issue, thus revealing their proclivity to cause trouble. The institution can then neutralize or eliminate the individual through sanctions invoked under informal procedures. Although some institutional standards of fairness may exist, due process tends to be relatively ineffective at this level. The individual under scrutiny often must forego all legal claims under the external law of the state and embrace the demands of the internal law of the group in order to avoid some of the more dire consequences of being named a "troublemaker."

In fact, every controversy can be analyzed from this dual perspective: what the law of the state outwardly mandates and what unwritten private law internally demands. The law of the state may, on occasion, adapt itself to the

266. For an example of such a violation with severe consequences, see Lopucki v. Ford Motor Co., 311 N.W.2d 338 (Mich. Ct. App. 1981) (holding work-related suicide is compensable under state law).

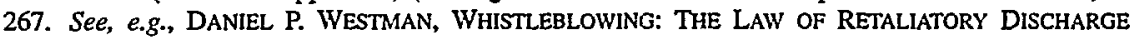
(1991); see also MASHBURN, supra notes 241, at 783-84, 788 (describing how professional duty of attorneys to report unethical conduct of other attorneys violates operative rule among lawyers: "Do not report other attoneys").

In cases of this nature, as in the whistleblower situations, an attorney could commit a form of malpractice, even though advice to the client was correct under the law of the state. This could happen if the attorney neglected to point out the risks of private sanctions. In other words, an attorney could be under a legal duty to know the external law of the state and, in addition, to be informed of potential risks that result from private lawmaking within the institution or business employing the client.

268. See, e.g., Connell v. Higginbotham, 403 U.S. 207 (1971) (per curiam), aff'g in part and rev'g in part 305 F. Supp. 445 (M.D. Fla. 1969) (holding Florida statutory loyalty oath, in its unconstitutional portion, cannot provide for dismissal without hearing or inquiry required by due process). After lengthy negotiations about the terms of reinstatement, a dismissed professor affected by the ruling decided to stay at his new location. 
demands of private lawmaking. But in most cases of direct clashes between the two, private lawmaking in one form or another will prevail. ${ }^{269}$

\section{Laws of Evidence}

\section{Absence of Exclusionary Rules}

Rules of evidence play a critical role in Gypsy law. They encourage a broad scope of inquiry and, contrary to non-Gypsy proceedings, are not designed to keep out information which is only remotely related to the controversy. Neither exclusionary rules nor rules against hearsay evidence exist: ${ }^{270}$ the parties or their spokesmen may speak freely and at length about their grievances. Similarly, the witnesses may present their testimony colorfully and expansively. In short, they may refer to past events, use exaggerations, and try to gain the favor of the judges and audience. The presentation of facts does not focus on clarifying a single issue.

To evaluate the disparity between Gypsy and gajikane standards of evidence one must examine the purposes of a broad scope of inquiry. The Gypsies appear to be concerned primarily with the presentation of a complete picture of events and evidence, even at the expense of what non-Gypsies might call due process and the rights of the individual. The litigants air their grievances before representatives of a tightly knit group who will most likely be very familiar with every aspect of their lives. Audience members come

269. In clashes between gajikano law (the law of the state) and romaniya (Gypsy law), the latter is likely to prevail. See supra notes $168-83$ and accompanying text; see also GROPPER, supra note 79 , at 103-06; Tillhagen, $V$, supra note 145 , at 131-33.

Similar dynamics prevail within Gypsy law. A Rom may be entitled to a legal remedy through a kris. However, according to competing norms of a more private nature, see supra note 99, a stigma attaches to one who informs on another Rom. In a case reported in YOORS, GYPSIES, supra note 42, at 176-79, a Gypsy woman stole some gold coins from another Gypsy woman. A kris was held to detect the Rom who had committed this serious offense, but she escaped detection by falsely swearing an oath as to her innocence, in spite of the curse that she might die in horrible pain. Much later, upon her deathbed, she confessed in agony to her misdeed and the coins were recovered. Nevertheless, the original victim felt guilty for having initiated the proceedings which had seemingly caused the death. In her view, this was an indirect murder. GROPPER, supra note 79, at 97 (reporting interview with Yoors supplementing his earlier account with additional facts).

According to a Gypsy source, the traditional Romani form of initiating a complaint by skirt-tossing as a means to contaminate the alleged offender is now discredited among American Gypsies. Attempting such an act might cause the skirt-tosser and her family to become marime themselves. See Jeatran, Social Control, supra note 139 , at 27 . This report seems to indicate that private norms of proper conduct sometimes prevail over the more archaic norms of Gypsy law, thereby bringing about change.

270. See supra notes $140-45$ and accompanying text. These assertions are based on the characteristics of tribal adjudications, as developed by Holleman, supra note 20, at 5-9. Although Holleman was concerned with African tribal law, similar observations have been made about the kris of the Vlax Gypsies. See, e.g., GROPPER, supra note 79, at 81-85; MCLAUGHLIN, supra note 58, at 23-24; Yoors, Lowari Law, supra note 126, at 12-17. A scheme of cross-cultural procedural preferences has been suggested by Stephen LaTour, Pauline Houlden, Laurens Walker, and John Thibaut. The degree of disputant control over evidence presentation is a crucial factor for parties' satisfaction with the procedures followed and the outcomes thereof. Stephen LaTour et al., Procedure: Transnational Perspectives and Preferences, 86 YALE L.J. 258, 280-84 (1976). 
from the same community as the parties, and thus follow the proceedings with an intense sense of participation and a strong desire that justice be done. This attitude may lead to spontaneous offers of testimony, as well as expressions of approval or disapproval from the audience. ${ }^{271}$ Evidentiary relevance cannot be determined in advance, but rather gradually emerges as the discussion progresses.

While the judges have been chosen because of their personal authority, ${ }^{272}$ they are expected to allow behavior that might be considered prejudicial or disruptive in non-Gypsy trials. Participation by the audience is expected and encouraged by custom. Members of the audience, although not formally called as witnesses, may feel justified in expressing views. Whether their contribution to the proceedings is based on personal observation or opinion does not matter. Ultimately the judge does not apply an exclusionary standard of relevance, but rather weighs the probative value of the cumulative evidence to make rulings. The extent to which the decisionmakers can identify with what has been said might be a significant standard in the mind of the judge as he assesses the probative weight of the evidence. Parties or witnesses will be perceived as credible if their statements have "the ring of truth." A person who can demonstrate in court that he or she has conformed to accepted communal standards may also be considered credible by the court.

A method of proof dependent on communal standards may at first appear prejudicial under our conceptions of legal theory. Nonetheless, it may in fact closely resemble what often transpires in our own courtrooms, especially when a jury makes the determination of fact. In a closely knit society, such as that of the Gypsies, this method of presenting and evaluating evidence may be as accurate as possible under the circumstances. The vindication of individuals' rights, as understood in a non-Gypsy context, is not of the utmost significance in a Gypsy kris. Instead, the reestablishment of peace in the group is the proceeding's prime objective; because all participants share essentially the same social values, the proceedings of the kris can easily be accepted by the entirety of the concerned population. Individuals will view themselves as members of a larger group that has been treated in accordance with the law, even if they lose the case. A feeling that justice has prevailed pervades. ${ }^{273}$

271. See, e.g., GROPPER, supra note 79, at 83 (viewing the audience as a form of "jury"); MCLAUGHLIN, supra note 58, at 24 (noting that members of audience act as devil's advocates); Lee, Kris, supra note 51, at 26 (noting that members of audience may question witnesses and argue about testimony); Tilihagen, III, supra note 130, at 24 (noting that audience may remind court of incidents that litigants have forgotten or did not want to raise).

272. See GROPPER, supra note 79, at 82 (noting high respect for certain judges); Lee, Kris, supra note 51 , at 25 (noting high repute and distinguished track record of judges).

273. The tradition of having a feast upon termination of the kris symbolizes the cathartic effect of the proceedings. Custom requires that the aggrieved parties and others involved be present. Tillhagen, $V$, supra note 145, at 127 (loser is usually host; sometimes winner pays); Yoors, Lowari Law, supra note 126, at 9 (stating that in spirit of reconciliation winner pays in carefree manner). Of course, if the sentence is for temporary or permanent marime there is no celebration. Yet if at a later time after a separate kris the 


\section{Getting at the Roots of Controversy}

This account, although somewhat speculative, suggests that the basic policies governing the admission of evidence in Gypsy societies are drastically different from those of the law of the state. By extending the judicial inquiry to remote aspects of the controversy, such as matters of the distant past, the proceedings will be more likely to uncover the roots of the current trouble. As a consequence of this process, the parties feel satisfied that they had an opportunity to be fully heard. ${ }^{274}$ A skillful judge, aided by the spokesmen of the litigants and assisted by the audience, may steer the parties toward a possible settlement. In such instances, the spokesmen act more as mediators than as attorneys. ${ }^{275}$

These types of resolutions are favored over the drastic sanction of a sentence of marime. The whole proceeding aims to reestablish peace between the warring parties by exposing and hopefully eradicating the source of disruption. The proceedings must also make the participants feel respect and appreciation for their leaders, their peers, the kris, and the law. For Gypsy societies, surrounded by a foreign and essentially hostile environment and dependent upon mutual assistance and good fellowship, such conciliatory results and evidentiary methods are vitally important. Even when sanctions such as temporary marime must be imposed, they are likely to be accepted because they are based on ancient custom and because there is little other choice. ${ }^{276}$

marime is lifted, the rehabilitated Rom rejoins the community in a "ritual of commensality." See Miller, Defilement, supra note 62, at 52 . The social life of a Gypsy centers around commensality, the spiritual and moral bond created by sharing food and drink. Miller, Thesis, supra note 63, at 17-19. Commensality is antithetical to rejection or pollution (which may occur by being publicly defiled by a woman tossing her skirt or by being declared marime in a kris). The resulting state of pollution means that commensality is to be withheld from the rejected person. Id. at 19. Consequently, any ceremonial readmission to the Romani community involves joint eating and drinking celebrations, which symbolize that the Gypsy concerned is again in good graces. Id. at 20-21. Reinstatement involves "a long, arduous and expensive procedure requiring frequent appeals for a new kris and new evidence." Id. at 42 n.7.

274. Similar observations have been made by Holleman, supra note 20 , at 6 , in discussing standards of pleading and proof in African tribal procedures. Since the controversy may have a long history, the parties are urged to reveal even remote aspects. Although individual redress is sought, the parties are also concerned with reestablishing their esteem in the community.

275. In matters conceming damages or payment of debts the parties are assumed to have made their requests with an implicit understanding that bargaining may take place within certain margins. The judge is expected to become active within these boundaries. Tillhagen, III, supra note 130, at 25 (discussing Roma in Sweden).

276. This presentation corresponds to the aspirations of romaniya (Gypsy law). In reality, Romani participants may sometimes be dissatisfied with the actual or potential dispositions of a $k r i s$ and resort to "extralegal" remedies, such as moving elsewhere. Lee, Kris, supra note 51, at 31-32 (describing how Canadian Rom avoided jurisdiction of kris by disappearing); Tillhagen, $V$, supra note 145, at 127-30 (discussing self-help); see also GROPPER, supra note 79, at 102 (stating that institution of kris is predicated upon "voluntary participation"); YoORS, GYPSIES, supra note 42, at 174 (noting that kris may have to resort to supernatural sanctions, such as curses, to prevent defiance). 
The exclusion of evidence in adjudications under the laws of the state rests on assumptions different from those of the kris. ${ }^{277}$ In a legal culture such as that of the United States inquiries are narrowed to lessen confusion and conflict among groups holding a diverse set of values. Procedures limit the trial to a narrow scope of inquiry, whether or not other matters appear relevant to a party. The non-Gypsy system presumes that a wide range of investigation may cause more trouble than benefits. Matters of a personal or intimate nature may not be raised if they would infringe on individual rights, even if justice in the isolated case before the court would be better served by the disclosure. A broad scope of inquiry would inevitably slow down the proceedings, and may also distract attention from the specific incidents that have triggered the controversy. Most importantly, the litigants in our culture do not have confidence that they share basic values with others who are involved in the process. To allow floods of complaints and grievances under such circumstances would serve no beneficial purpose. The narrow focus of inquiry in adjudicative proceedings ${ }^{278}$ therefore seems to suggest that a society such as the United States has highly diverse basic values, many of which are not compatible with each other.

In the state law adjudication system, the losing party will likely feel that justice has not been served by the narrow inquiry, since exclusionary rules of evidence prevented, in the loser's view, a full presentation of the case. As a result, parties do not fully trust judges, and they suspect attorneys of being manipulators and hairsplitters. ${ }^{279}$ In contrast, private lawmaking has more in common with tribal law and the proceedings in the kris. Within an institutional or otherwise private context, controversies tend to be discussed and settled without the use of exclusionary rules of evidence, and are usually not even as formal as the kris of the Vlax. A skillful leader in this setting will draw on communal support much as an experienced tribal chief would, rather than relying on rigid rules or running roughshod over the proceedings. This use of private lawmaking inevitably involves resort to custom. The laws of the state, with their exclusionary standards of evidence and relevance, will be invoked only when institutional resources have failed. Even in these instances, the rigidity of the laws of the state will be tempered by the customs of private lawmaking. ${ }^{280}$

277. For a comparison of restrictive western standards of evidence with all-inclusive standards in African tribal law, see Holleman, supra note 20, at 5-9. The principles developed in that article are fully applicable to the procedure of the kris, as practiced by the Vlax group of the Romani people. For further details, see Johan F. Holleman, Some Problems of Evidence in Shona Tribal Law, in STUDIES IN AFRICAN Social ANTHRopology 75 (Meyer Fortes \& Sheila Patterson eds., 1975).

278. Weyrauch, Law as Mask, supra note 244, at 706.

279. This is a perennial complaint about American law. See, e.g., AlBRECHT MENDELSSOHNBARTHOLDY, DAS IMPERIUM DES RICHTERS 151 (1908).

280. See supra notes 243 and 248 and accompanying text. 
Much unnoticed and informal lawmaking and adjudication takes place in many legal systems. The private law aspects of proceedings before the kris of the Vlax find their parallels in other widely disparate legal cultures. The role of the chief as judge, the participation of the audience in the proceedings, the broad scope of inquiry, and the effort to mediate and expose the roots of the controversy find surprising parallels in African tribal adjudications ${ }^{281}$ as well as in Asian societies such as China and Japan. ${ }^{282}$ The extraordinary efficacy of private lawmaking (which may cross the line of oppressiveness) has occasionally been exploited in state attempts to impose a particular ideology at the local level, where it can have its strongest effect. The Chinese have used private lawmaking in this way in mediations and adjudications where efforts to get "to the roots of the problem" are perceived as ideological struggles. ${ }^{283}$ In Cuba, similar attempts have been made to politicize and control neighborhoods. ${ }^{284}$ But these efforts ignore the reality that private lawmaking is almost impossible to control, even in repressive societies. It takes place at all times and places; it is of ancient origin and universal application.

\section{General Considerations}

Looking at the broad definition of law articulated at the outset of this Article, ${ }^{285}$ several observations can be made about romaniya, or Gypsy law, and other forms of private lawmaking. Although the Romani people do not formally gather to pursue an objective, their need to survive as a distinct and isolated group provides them with a common purpose; Gypsy law ensures that host countries' legal systems and cultures minimally influence Gypsy life. Although romaniya has sacred aspects that direct Gypsies to lead their lives

281. See Holleman, supra note 20 , at 6-7.

282. On China, see Roger Grace, Justice, Chinese Style, CASE \& COM., Jan.-Feb. 1970, at 50 (discussing dispute settlement in Chinese-American communities); Stanley Lubman, Mao and Mediation: Politics and Dispute Resolution in Communist China, 55 CAL. L. REV. 1284 (1967). On Japan, see RUDOLF B. SChLESINGER ET AL., COMPARATIVE LAW 332-34 \& n.108 (5th ed. 1988) (observing that private lawmaking still prevails in country as highly developed as Japan and even affects proceedings before ordinary courts and administrative agencies); Nobuaki Iwai, The Judge as Mediator: The Japanese Experience, 10 CIV. JUST. Q. 108 (1991); Joel Rosch, Institutionalizing Mediation: The Evolution of the Civil Liberties Bureau in Japan, 21 LAW \& SOC'Y REV. 243 (1987).

283. For a detailed report by a New York state justice who attended a criminal trial in China, see Mary J. Lowe, The Trial of Ran Kao-chien, JURIS DR., Apr. 1978, at 12. The Chinese trial had many parallels with the kris of the Vlax, in particular the wide scope of what is considered relevant; the absence of evidentiary, constitutional, and procedural hurdles; representation by nonprofessional advocates; and participation of the audience. Ideological elements included judicial exhortations to confess. See also Lubman, supra note 282.

284. Jesse Berman, The Cuban Popular Tribunals, 69 CoLuM. L. REv. 1317 (1969). But see Luis Salas, The Emergence and Decline of the Cuban Popular Tribunals, 17 LAW \& SoC'Y REV. 587 (1983) (describing increased formality imposed after popular courts came under criticism); Luis Salas, The Judicial System in Postrevolutionary Cuba, 8 NovA L.J. 43 (1983) (traditional western procedural safeguards reinstituted). Fidel Castro presumably came to perceive the Popular Tribunals as a potential threat to his regime; he could not control them to the extent he had anticipated.

285. See supra text accompanying note 8. 
properly by attaining a state of purity and preventing contamination, it does not advocate proselytizing or imposing its values on non-Gypsies. Its main purpose is to achieve a state of balance (kintála) that pleases the spirits of the ancestors (mulê). ${ }^{286}$ Conversion of the gaje would not make much sense because they and their ancestors are outside the Gypsy universe.

Dissent within the Gypsy community is possible only in a limited number of realms, such as economic matters and territorial disputes. Dissent is not permitted with regard to basic social taboos. Outside the romaniya, there is not much conceded lawmaking within Gypsy communities. Some forms of behavior are tolerated if they are done with discretion and not openly acknowledged. For example, young male Gypsies may gain sexual experience with non-Gypsy women, provided there is no romantic involvement. ${ }^{287}$ Yet these matters continue to be viewed as deviant behavior and do not become part of romaniya. ${ }^{288}$ They are not even viewed as custom because there is no acknowledged difference between custom and law. If common behavior creates visible problems, such as women wearing jeans instead of long skirts, a divano or kris may be called. ${ }^{289}$

By comparison, non-Gypsy forms of private lawmaking are equally concerned with cohesion and survival of the group, at least with regard to their own distinct characteristics, but they tend to be more vulnerable to external influences than Gypsy law. If they have aspirational functions, they are less directed toward lofty moral ideals than toward maintenance of group cohesion. Instead of an internalized demand for purity, such systems may stress unwavering group loyalty. Even mere suspicion of disloyalty may lead to severe sanctions. Adjudication is done informally and without attention to traditional standards of fairness, such as the right to be heard. ${ }^{290}$ In the vast majority of cases, the law of the state is incapable of, perhaps not even concerned with, remedying any unfairness that may have occurred in these private lawmaking systems. Most of the oppressive aspects of private lawmaking occur outside the scope or even vision of state authorities. While some may find unsettling the idea that any small group can engage in

286. Hancock, World Citizens, supra note 170 (manuscript at 5). The conceptions of romaniya are of ancient Indian origin and thus not part of the Judeo-Christian tradition. Interestingly, Cover, supra note 6, at $11 \mathrm{n.31}$, uses similar language in describing the Torah as one of the pillars of Judaism: "The Hebrew 'Torah' refers both to law in the sense of a body of regulation and, by extension, to the corpus of all related normative material and to the teaching and learning of those primary and secondary sources. In this fully extended sense, the term embraces life itself, or at least the normative dimension of it ...."

287. Hancock, Review, supra note 35 , at 77-78.

288. Perhaps the routine consumption of alcoholic beverages during Prohibition is comparable. Cover, supra note 6, at $21 \mathrm{n} .63$, calls this a "fact of life" rather than an assertion of revolutionary lawmaking power.

289. See Hancock, Letter, supra note 151, at 5 n.46. On the other hand, Gypsy society, just as any other society, may in fact be permeated by autonomous subsystems which sometimes deviate from binding rules of romaniya. Thus, a Gypsy family may relax some restrictions within the confines of the home and intimate life. See supra note 99.

290. See supra text accompanying notes $265-68$. 
lawmaking, such lawmaking is a manifestation of inherent human needs. ${ }^{291}$ By imposing a yardstick for measurement of "worthiness" we also project external standards that have no more intrinsic claim for accuracy than any other standard, although the observer positioned outside of the group may strongly sympathize with such universal standards. ${ }^{292}$

A significant difference between Gypsy law and other forms of private lawmaking may be that the members of gajikane groups are also members of numerous other gatherings and participate in a wide range of social discourse. A law firm, for example, is divided into various subgroups, such as partners, executive committees, junior partners, associates, and staff members, each having its own sets of legal norms and implicit threats of sanctions. ${ }^{293}$ The members of the firm are also members of families and participants in a great number of social organizations, some of them recognized under state law, others more or less invisible. Each of these groups has its own autonomous legal system that is not necessarily compatible with the laws of the other groups or with those of the law firm. This situation results in internal adjustments by the individual member to these multiple social institutions. The resulting accommodations, although reached individually, must have an impact on the laws of all of the groups concerned. True isolation in gajikane society is utopian, and the continuing adjustments that are achieved on an internal and individual level are bound to be reflected in lawmaking within each group and even externally in the laws of the state. ${ }^{294}$ From that perspective the dichotomy between private lawmaking and the law of the state disappears, and law, even in its traditional form, can be viewed as a network of small-group interactions.

Such a view of law cannot be applicable in the same degree to the Gypsies, who by choice avoid exposure to conflicting loyalties with the outside world. Nevertheless, although they need and depend on contacts with their host countries as a source of their livelihood, ${ }^{295}$ they do not want to be part of these societies in any sense that would involve compromise of their basic beliefs. It is romaniya that makes such separation possible. If there is any semblance of compromise, it may be in the Gypsies' willingness to adapt to

291. Weyrauch, Basic Law, supra note 6, at 58 .

292. Cover has maintained that the law created by the Mennonites, for purposés of constitutional meaning, assumes an equal or superior status to the law as interpreted by the Justices of the Supreme Court. Cover, supra note 6, at 28 (referring to Bob Jones Univ. v. United States, 461 U.S. 574 (1983)). With regard to the important problem of human rights standards raised in Reisman, Comment, supra note 46, at 416, see Walter $O$. Weyrauch, On Definitions, Tautologies, and Ethnocentrism in Regard to Universal Human Rights, in HUMAN RIGHTS 198, 199-200 (Ervin H. Pollack ed., 1971) (discussing difficulties in defining universal human rights).

293. Weyrauch, Legal Profession, supra note 22, at 480-81.

294. See Cover, supra note 6 , at 30-33 (referring to CAROL WEISBROD, ThE Boundaries of UTOPIA (1980)); Stone, supra note 6, at 891-92; Weyrauch, Basic Law, supra note 6, at 56-58.

295. OKELY, TRAVELLER, supra note 62 , at 28-29. 
the requirements of their surroundings, although by adapting a Gypsy risks being assimilated or losing his or her identity as a "Gypsy."296

This isolation of the Romani people is sustained not only by centuries of persecution, but also by their deep commitment to retain their ethnic identity. Although they live among their hosts, Romani reservations about the hosts are strong and, considering historical events, understandable. Perhaps only isolated island communities have succeeded to a greater degree than the Gypsies in maintaining their almost utopian autonomy. A rare illustration is Tristan da Cunha, a territory of the British Colony of St. Helena, midway between Africa and South America. ${ }^{297}$ In this case, the separation is physical, with thousands of miles of ocean in every direction and only sporadic communications with the outside world. ${ }^{298}$ The fewer than three hundred island inhabitants have developed a unique legal system recognizing no leadership of any sort and no communal decision process. ${ }^{299}$ There is no crime or violence. The main sanction for misbehavior is teasing, a powerful deterrent because the island's inhabitants have nowhere to go to escape. ${ }^{300}$ The most serious violations are assuming a position of superiority and interfering in any way with the life of other inhabitants. The population is reserved but good-natured and cooperative toward occasional visitors.

Tristan da Cunha has no religious history. It was founded as a business partnership between the three initial settlers who were the ancestors of the present population. The partnership document, dated November 7, 1817, expressed a fundamental conception of absolute equality. ${ }^{301}$ It provided, in part: "That in order to ensure the harmony of the Firm, No member shall assume any superiority whatever, but all to be considered as equal in every respect, each performing his proportion of labour, if not prevented by sickness ...." ${ }^{302}$ This was later amended by a document of December 10, 1821,

296. See supra notes 213-17 and accompanying text.

297. For details, see generally PETER A. MUNCH, CRISIS IN UTOPIA: THE ORDEAL OF TRISTAN DA CUNHA (1971).

298. The decline of sailing ships seems to have increased the isolation for many years. The inhabitants of the islands are said to have learned about World War I only after it was almost over. Carl Mydans, Strange Story of a Flight from Our Century: Far-Off Exiles of Tristan, LiFE, July 12,1963, at 72; see also MUNCH, supra note 297, at 94.

299. MUNCH, supra note 297, at 1-18, 74-91; Letter from Peter A. Munch, Professor of Sociology, Southern Illinois University at Carbondale, to Walter O. Weyrauch (May 5, 1977) (on file with authors) (referring to unpublished student paper about informal legal system of Tristan da Cunha: "[She] has not in my opinion recognized the full impact of the 'legal system' (if one can call it that) of anarchism in Tristan da Cunha: Looking for 'leaders' and instruments of communal 'decisions,' she did not seem to recognize that at the time she was concerned with, no instrument of communal decision existed on the island, and anyone who would assume the role of a 'leader' would find himself without followers and would be the object of the subtle sanction of avoidance because he would have deviated from the accepted pattern of proper behavior ....."); see also Peter A. Munch, Anarchy and Anomie in an Atomistic Community, 9 MAN 243, 250-58 (1974).

300. Mydans, supra note 298 , at 77.

301. The full text of the partnership agreement is reproduced in MUNCH, supra note 297, at 29-30. The original partnership document is now in the British Museum.

302. Id. at 29. 
signed by all male members of the community: "No person subscribing to these articles are [sic] to continue reminding particular persons of their Duty in point of Work, or otherwise, as in such Case nothing but Disunion will be the consequence ...."303 These formal pronouncements were later transformed by custom into the utopian legal microsociety which still exists today. It seems clear that such a normative state of mind can only be achieved in situations of extreme geographical isolation. Although the Romani people may come close, none of the groups engaged in private lawmaking discussed in this Article can quite match such successful isolation.

\section{CONCLUSION}

The traditional view that law emanates from the state is too narrow. Numerous sources of private lawmaking, though little noticed, coexist with the law of the state. This autonomous lawmaking takes place imperceptibly within institutions, corporations, families, and wherever else people join together to pursue common objectives. Violation of these informal legal norms, as in the case of any other infraction of law, results in sanctions applied in private adjudications. In many respects, these private legal systems have characteristics similar to those found in tribal law. They are based on highly persuasive oral traditions that easily adapt to changed conditions. Language plays an important role in these systems, not only in terms of what is articulated, but also in terms of what can be inferred and understood in any given setting. If a dispute arises, any form of evidence, including evidence regarding remote events, can be submitted to help get at the source of the particular disturbance. Due process in the American legal sense is markedly absent. Shared values and communal peace, not individual rights, are the prime interests protected.

In view of the many similarities between private lawmaking and tribal law, the legal system of the Gypsies provides a useful vehicle for developing theory. Like other forms of autonomous lawmaking, it is hardly noticed, although it competes effectively with the laws of the host culture. It assures the survival of the group by emphasizing group loyalty and relationships over the rights of individual members, and it usually prevails when it comes into open clashes with the surrounding legal system of the state.

303. Id. at 37. Professor Robert M. Cover essentially described Tristan da Cunha when he theorized about an imaginary world:

In an imaginary world in which violence played no part in life, law would indeed grow exclusively from the hermeneutic impulse-the human need to create and interpret texts. Law would develop within small communities of mutually committed individuals who cared about the text, about what each made of the text, and about one another and the common life they shared. Such communities might split over major issues of interpretation, but the bonds of social life and mutual concern would permit some interpretive divergence.

Cover, supra note 6, at 40 (citation omitted); see also Stone, supra note 6, at 828-29 (discussing legal visions within Jewish communities). 
Studying the capacity of any form of private lawmaking to prevail over or influence official state law enriches legal theory and practice. Clashes between informal institutional law and the traditional law of the state are frequent and unavoidable. Yet because participants and decisionmakers traditionally do not regard private law as law, such norms seldom appear openly in court. Instead, private law rules are communicated by way of appropriate hints and suggestions, and are injected into traditional state law by means of interpretation and construction. These norms influence decisions on the probative value of evidence. And what is commonly called strategy is in actuality often an application of the norms of private lawmaking. Juries are inevitably sensitized to oblique innuendo. Even judges, in their interpretation of legal materials and in their judgment of the merits of argument, will likely be swayed by skillfully placed implications. None of this process ordinarily reaches the level of consciousness. Yet advocates who are able to base their arguments on unstated innuendo are likely to have an advantage. By contrast, attorneys who base their arguments on the letter of state law may lose persuasive power.

But state law and private law commonly interact more subtly than in direct confrontation. For example, the law of the state may greatly influence the internal norms of a law firm both through direct regulation and indirectly through implicit mores which influence the interaction of members of the firm. State law also influences the law of the Gypsies, albeit to a lesser extent. Gypsies may acquiesce to some aspects of state law because of economic necessity, for example, by conforming to administrative laws on regulation of business. In addition, Gypsies may have adjusted the laws of their own legal system to the laws of their host countries, particularly if these adjustments do not clash with their values. The Romani rejection of most crimes of violence provides an example.

As this Article has demonstrated, autonomous systems also have powerful influence in shaping state law. Just as oral traditions and unarticulated cultural norms may play a great role in determining the outcome of disputes in the formal justice system of the state, values in autonomous systems may gradually shape the very substance of state law. The Gypsy system is no exception. As the state either fails to enforce its own norms or overtly acknowledges the value of norms embodied in the Romani legal system, it responds to the influence of the autonomous system.

Thus, law reveals itself as a multitude of autonomous systems operating simultaneously with the formal law of the state. Each system shapes the other systems with which it has contact. Only total isolation will prevent any legal system from being shaped by others. Indeed some isolation is required for any autonomous system to be truly "autonomous," for any group with such a system must be insular to some extent. The degree of that insularity determines the shape and the strength of the autonomous system itself. 
As far as American law is concerned, readers may find the degree of de facto autonomy given to romaniya and to the kris of the Vlax surprising. They may also find the autonomous informal adjudications in our own private lawmaking disturbing. Some may prefer to call these adjudications arbitrary and contrary to American ideals and do not think that they should be part of the definition of law at all. Yet private lawmaking here and elsewhere can hardly be successfully regulated or suppressed, except perhaps by relegating it to the sphere of the unconscious. In addition, it cannot be prevented from filtering into the traditional proceedings under the law of the state. But it is not proper to view private lawmaking as a negative phenomenon. Autonomous legal systems run inextricably through state law. If our traditional legal proceedings have any effectiveness, it is because of the features of submerged private lawmaking they possess-features that respond to a desire for group cohesion and satisfy fundamental human needs. If private lawmaking were more widely recognized, much of the gap between theory and practice could be narrowed or at least more effectively explored in an analytical fashion. The theoretical structure of law could be revitalized, and perhaps the application of state-made law would even gain somewhat in popular acceptance. 
